\title{
Trade unions and informal workers' associations in the urban informal economy of Ecuador
}

\author{
Working Paper No 57
}

\section{Catherine Vaillancourt-Laflamme}

\author{
Policy Integration Department \\ International Labour Office \\ Geneva
}

February 2005 
Copyright (C) International Labour Organization 2005

Publications of the International Labour Office enjoy copyright under Protocol 2 of the Universal Copyright Convention. Nevertheless, short excerpts from them may be reproduced without authorization, on condition that the source is indicated. For rights of reproduction or translation, application should be made to the Publications Bureau (Rights and Permissions), International Labour Office, CH-1211 Geneva 22, Switzerland. The International Labour Office welcomes such applications.

Libraries, institutions and other users registered in the United Kingdom with the Copyright Licensing Agency, 90 Tottenham Court Road, London W1T 4LP [Fax: (+44) (0)20 7631 5500; email: cla@cla.co.uk], in the United States with the Copyright Clearance Center, 222 Rosewood Drive, Danvers, MA 01923 [Fax: (+1) (978) 750 4470; email: info@copyright.com] or in other countries with associated Reproduction Rights Organizations, may make photocopies in accordance with the licences issued to them for this purpose.

\section{ISBN 92-2-117921-4 (printed version)}

92-2-117922-2 (web version)

First published 2005

Cover:

The designations employed in ILO publications, which are in conformity with United Nations practice, and the presentation of material therein do not imply the expression of any opinion whatsoever on the part of the International Labour Office concerning the legal status of any country, area or territory or of its authorities, or concerning the delimitation of its frontiers.

The responsibility for opinions expressed in signed articles, studies and other contributions rests solely with their authors, and publication does not constitute an endorsement by the International Labour Office of the opinions expressed in them.

Reference to names of firms and commercial products and processes does not imply their endorsement by the International Labour Office, and any failure to mention a particular firm, commercial product or process is not a sign of disapproval.

ILO publications can be obtained through major booksellers or ILO local offices in many countries, or direct from ILO Publications, International Labour Office, $\mathrm{CH}-1211$ Geneva 22, Switzerland. Catalogues or lists of new publications are available free of charge from the above address, or by email: pubvente@ilo.org

Visit our website: www.ilo.org/publns 


\section{Contents}

Preface.

Introduction ............................................................................................................................................... 1

Methodology ….................................................................................................................................................. 3

Ecuador: a brief survey ....................................................................................................................................... 4

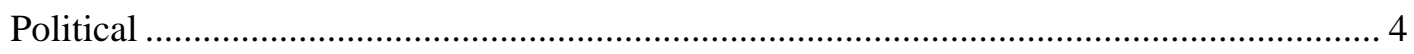

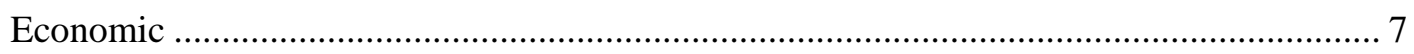

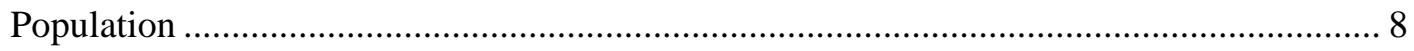

Informal economy: taking into account the changing times............................................................ 22

Representation and voice: Increasing the statistical visibility of vulnerable workers ........... 27

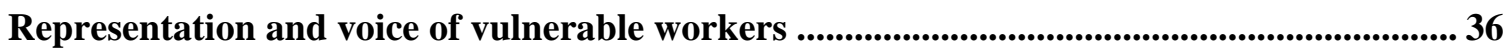

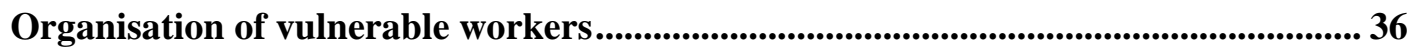

Organizing vulnerable workers through unions......................................................... 37

The point of view of vulnerable workers' associations ................................... 39

The point of view of labour organizations....................................................... 40

Vulnerable workers forming autonomous associations .......................................... 42

The point of view of the vulnerable workers' associations ............................. 43

The point of view of labour organizations.................................................... 46

Vulnerable workers organizing on the basis of cultural identity............................. 48

Representation of vulnerable workers ................................................................................... 51

Representation in official institutions: social dialogue and tripartism..................... 52

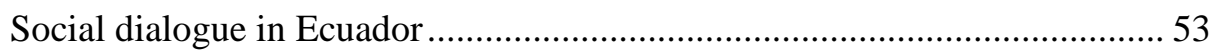

Social dialogue and good governance ........................................................ 56

Including vulnerable workers in social dialogue ............................................ 57

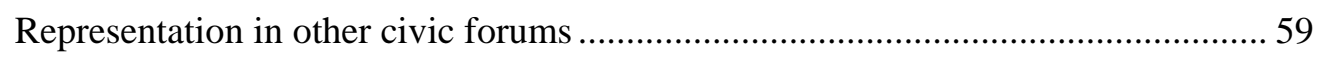

The hemispheric social alliance and the Free Trade Agreement in the

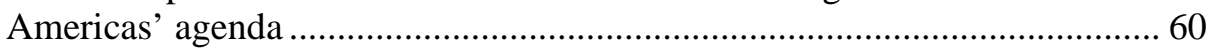

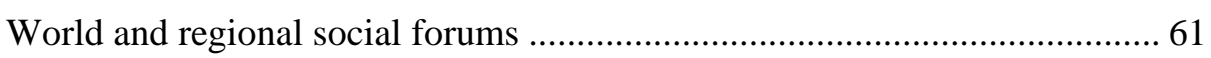

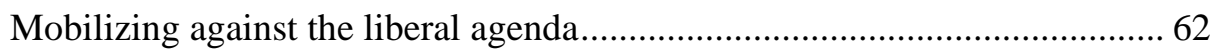

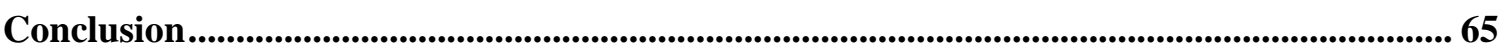

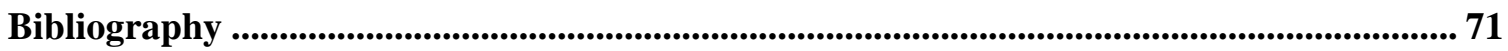

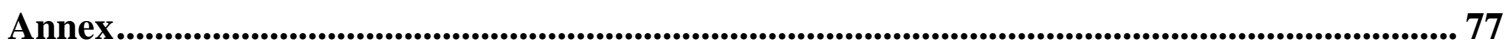




\section{Preface}

Within the ILO, the Policy Integration Department was asked to lead the follow up to the 2002 International Labour Conference which dealt with the informal economy and decent work ${ }^{1}$. One of the conclusions adopted by the ILC was the need to better understand the phenomenon of the informal economy and particularly the issue of voice and representation of the informal workers.

This Working Paper, which to forms part of a knowledge-sharing project on the informal economy, provides thought-provoking insights into the situation of Brazil workers in the context of urban Ecuador. Based on rich interviews, it examines ways to increase the voice and representation of these informal economy actors as necessary steps in combating poverty.

As a Working Papers, this document is intended to stimulate discussion and encourage others to pursue further work to expand knowledge in relation to the ILO's Decent Work Agenda.

\section{Anne Trebilcock \\ Director ad interim \\ Policy Integration Department}

September 2005

\footnotetext{
${ }^{1}$ ILO. 2002. Conclusions concerning decent work and the informal economy, International Labour Conference, 90th session 2002, Provisional Record, No. 25 and. Report VI. (Geneva: ILO)
} 


\section{Acknowledgements}

Many people come to mind for their help, insights and encouragement for this Working Paper. At the risk of leaving some people unnamed, I want to thank Rafael Diez de Medina for his guidance and leadership, Jorge Viteri for skilfully conducting the interviews on which this paper is based, Anne Trebilcock for her support and editing, Joanna Jackson for the knowledge she imparted on the informal economy, David Kucera for his numerical wisdom, and René Robert, for his humour and support when we shared an office. Lastly, I would like to recognize all the colleagues and friends whom I met thanks to the writing of this paper during my ILO internship, sponsored by the Québec (Canada) government. 


\section{Introduction}

This paper addresses the issue of representation and voice of informal workers, or more broadly vulnerable workers, in the context of the urban informal economy in Ecuador. The focus of the research was chosen because of the increasing number of informal workers and the decent work deficits these workers face on a day to day basis. Prominent among these many deficits is representation and voice - of critical importance as the base of many other labour and civic rights.

Informality can be an attribute of an enterprise or a job. Informal enterprises are private, unincorporated enterprises, owned by an individual, a family or group of people who are not independent from their owners (in terms of legal responsibility, for example). These enterprises produce goods or services for sale or barter. They are usually of a relatively small size, not registered under specific legislation, and their employees are not declared. Finally, for statistical purposes, informal enterprises are not involved in agricultural activities. $^{2}$

Informal employment "refers to the total number of informal jobs, whether carried out in formal sector enterprises, informal sector enterprises, or households, or to the total number of persons engaged in informal jobs during a reference period". ${ }^{3}$ It would include own account workers and employers, contributing family workers, employees who have informal jobs (in formal or informal enterprises), paid domestic workers, members of informal producers' cooperatives and employees in own account production of goods for their household's own final use.

This paper focuses on the specific situation of Ecuador, a country where more than $50 \%$ of the population works in vulnerable, mostly informal, employment situations. This country also has an important indigenous population, close to $40 \%$ of the population, which may well impact on the way these workers conceptualize their situation and form groups to better it.

From the early 1970s onward, the ILO has put a lot of energy into understanding what is now being called the informal economy (the term used earlier was the informal sector). From a phenomenon that was understood to be temporary, it is now rather seen as a structural situation. The number of informal economy workers around the world, not least in Latin America and particularly in Ecuador, has been rising rapidly. This trend is not seen as slowing down. ${ }^{4}$

In light of this situation, the ILO Director-General presented a report, The dilemma of the informal sector, to the International Labour Conference (ILC) in 1991. ${ }^{5}$ At that conference, delegates from governments, employers' and workers' organizations debated whether to promote the informal sector as a way to alleviate unemployment or, considering the many decent work deficits observed, formalize the informal sector, thereby perhaps risking

2 ILO. 2002. Compendium of official statistics on employment in the informal sector. STAT Working paper by Ralph Hussmanns and Brigitte du Jeu. Geneva: ILO/Bureau of Statistics, p. 3.

${ }^{3}$ Ibid., p. 4.

4 ILO. 2002. ILO Compendium of official statistics on employment in the informal sector. STAT Working Paper by Ralph Hussmanns and Brigitte du Jeu. Geneva: ILO/Bureau of Statistics.

5 ILO. 1991. The dilemma of the informal sector, Report of the Director-General, International Labour Conference, $78^{\text {th }}$ Session, ILO, Geneva. 
reduction in the number of jobs being created, increasing unemployment levels and the poverty associated with them.

In 2002, the ILC debated another Director-General's report on Decent work and the informal economy, ${ }^{6}$ and concluded that this dilemma was becoming a source of increasing concern. One issue raised was the negative consequences of deficits in relation to representation and voice, which often lead in turn to other labour rights not being exercised by workers in the informal economy.

Apart from the difficult task of giving the concept a concrete and accepted definition, much of the energy invested by the ILO has focused on the economic and legal dimensions of this phenomenon. Thanks to those efforts, the ILO now has many in-depth economic descriptions of the economic units that comprise the informal economy, excellent analyses of the legal constraints that those workers face in the process of "formalization," and vivid testimonies to the heterogeneity of this growing phenomenon and the many decent work deficits usually faced by informal workers.

In this paper, the issue of representation and voice is first addressed at a statistical level in order to increase the visibility of the informal workers. The need to improve the statistical picture of the informal economy was also pointed out by the 2002 ILC report on the informal economy and the conclusions adopted by the ILO's tripartite constituents. ${ }^{7}$ Too often, the size of registration criteria that is used does not suffice to identify the informal economy worker or unit that would need to be addressed by public policies in order to overcome various decent work deficits. The Compendium of official statistics on employment in the informal sector points out that for purpose of analysis and policymaking, it may be useful to disaggregate the different types of informal jobs.

In the case of Ecuador, we hope to present a statistical model that goes beyond the general criteria normally used to identify those that are in the informal economy and those that are not. In targeting with precision, among the so-called informal workers (own account workers, micro and small businesses), those that are in need of active public measures, we hope to ease the identification of vulnerable workers and the policy work that needs to be done towards improving the working and living condition of those workers. The approach presented is based on the estimation of the level of productivity of the informal economic unit as being the central discriminating feature. As such, the term "vulnerable workers" has been preferred in this Working Paper over "informal economy workers".

Beyond the statistical approach to the informal economy, a survey of the available literature shows that the socio-political dimension of the informal economy, and in particular the representation and voice of informal workers, has been much less studied. This has been pointed out by some of the organizations interviewed in the course of this

6 ILO. 2002. Decent work and the informal economy. Report of the Director-Genera, International Labour Conference, 90th Session, Report VI.

${ }^{7}$ Conclusions on decent work and the informal economy, International Labour Conference, $90^{\text {th }}$ Session (Geneva, 2002), Provisional Record, No. 25. 
research, as well as by some authors. ${ }^{8}$ Such a perspective might well be necessary for a deeper understanding of the complex politico-socio-economic relations that exist within the informal economy and their function in different national economies in the context of globalization. This perspective might just shed new light on the situation, with a view to arriving at adequate solutions to remedying decent work deficits.

The growing number of informal economy workers in many countries underscores the necessity of informal or vulnerable workers themselves having the opportunity to express their perceptions and to propose solutions to their many problems. These informal workers, often muted, need a voice. For this, they need to be represented and heard. In drawing on the many in-depth interviews with relevant actors in the Ecuadorian urban informal economy, including unions and informal economy associations, that were conducted for this study, this paper hopes to have gone one step further in having these workers' concerns heard. ${ }^{9}$ Ideally, this paper would be supplemented in future by the incorporation of the opinions of employers and government officials.

The following paper first presents some methodological notes on the data used. The political, economic and socio-demographic portrait of Ecuador is then provided. The next section intends to explain why, in the author's view, the concept of "informal economy" might not be the most fruitful one to understand the situation of Ecuador. A statistical model is presented that takes another look at identifying "vulnerable workers" using different indicators than those usually used. The issue of representation and voice of vulnerable workers is then divided into its organizational and representational components.

\section{Methodology}

The statistical model presented below is based on the work of the Corporación de Estudios para el Sector Informal (CEPESIU). Its presentation is not intended to close the debate on this matter. Rather, it aims at showing one possible, though not simple, model which permits the identification of informal economic units and vulnerable workers, whether formal or informal, in need of public support to strengthen their creativity and entrepreneurship.

The qualitative part of the data collection was done through a series of interviews with relevant informal economy actors, trade unions and informal workers' associations, in the two most important urban centres of Ecuador: Quito and Guayaquil. These interviews were conducted by Jorge Viteri between 14 June and 9 July 2004. Informants were asked a series of questions broadly related to their definition of the informal economy, the issue of representation and voice of informal economy workers and the best ways to improve this, if deemed insufficient.

8 See C. Maldonado, 2001. Participación de las organizaciones de comerciantes informales en el proceso político y las reformas institucionales a nivel local. Pautas metodológicas. Proyecto de investigacion (ILO - IFP/SEED/DECLARATION-ETM Lima). Lima: Oficina regional del trabajo, and J. Cross, 1998. Informal Politics: Street Vendors and the State in Mexico City. Stanford: Stanford California Press. p. 272.

${ }^{9}$ In the course of this investigation, government public servants, mostly in the Ministry of Labour, were also interviewed. Their views on the issue of voice and representation of informal workers are not reflected in this paper, since more information would be needed to include these perspectives. 
The interview grid was designed to let the informants express as openly as possible their opinions on the matters addressed. On average, each interview lasted a little more than an hour. These were conducted in Spanish. Most of the interviews were taped; those that were not were not included in the analysis. ${ }^{10}$

The criteria used to select the informants were as follows:

- The importance of the informant's relationship to the urban informal economy;

- The representation of the sector in relation to the informant's organization;

- The informant's experience in planning or executing programmes targeted to the urban informal economy;

- The informant's relationship to related informal economy themes such as gender and ethnicity.

Table A (see Annex) shows the organizations interviewed (trade union organization/federation, informal economy associations or other type of organizations).

\section{Ecuador: a brief survey}

\section{Political (situation up to January 2005)}

Ecuador has had civilian governments since 1979. These followed two military regimes (1963-1966; 1972-1979). From the 1980s onwards, a number of factors have made it difficult for stable government majorities with coherent policy agendas to form. ${ }^{11}$ The country is divided between the coastal regions and the highlands, and those divisions are reflected in the national political agenda. In parallel, "clientelism" (catering to specific constituencies) and corporatism have come to be the generalized way of conducting politics. $^{12}$

Since 1994, the political climate has been particularly unstable: seven different Presidents have led the country, accompanied by a change of Minister of Labour. This reflects popular discontent over fraud charges lodged against some of these presidents and political division amongst various political coalitions. In 1998, a new Constitution was adopted that did not result in a more stable political system. ${ }^{13}$ In January 2000, after a massive mobilization called mostly by the indigenous movement, the government was overthrown.

10 This was the case for the Federación de Comerciantes Minoristas de las Bahías in Guayaquil and the Coordinadora de politica de mujeres in Quito.

11 Economist Intelligence Unit. 2004. Ecuador. Country profile 2004. London : Economist Intelligence Unit, p. 4.

12 ILO. 2003. Análisis de las Políticas y Programas Sociales en Ecuador. Lima. OIT/Oficina Regional para las Américas/Programa IPEC. p. 18.

13 BID. 2002. Evaluación del Programa de País. Ecuador 1990-2002. Washington: BID/Oficina de Evaluacion y Supervisión. 
In May 2004, and more recently in November of the same year, President Lucio Gutierrez has faced impeachment. ${ }^{14}$

Many social movements have been very active in voicing their discontent at the way governments have handled the economic, social and political affairs of the country. Some of the largest movements are the Federación Ecuatoriana de Indios (FEI), the Confederación Nacional de Indígenas de Ecuador (CONAIE) and its various federations, and its political wing, the Movimiento Unidad Plurinacional Pachakútik, among others.

Indigenous movements are quite strong and constitute an incontrovertible political actor in Ecuador. In 1998, for instance, during the negotiations leading to the adoption of the Constitution, they won important gains on four major land right issues. Ecuador ratified ILO Convention No. 169, on indigenous and tribal peoples. Special political privileges were granted. The Consejo de Planificación de los Pueblos Indios was established, and some indigenous members were elected to the General Constitutional Assembly, the Congress and to various local institutions. At the same time, however, the development of trade unions suffered setbacks as they felt the impact of globalization and the reduction of the role of the State.

As many of the people interviewed suggested, a lack of good governance seems to be a driving force behind social, political and economic unrest. With a plea to end corruption at all levels, on 21 January 2000, the indigenous movement in Ecuador, led by the CONAIE, was at the centre of important protests that brought thousands of indigenous people to Quito, successfully overthrowing the government of A. Mahuad. For a few hours, the Parliament was headed by the National Parliament of the People of Ecuador, and a triumvirate of the then Colonel Lucio Gutiérrez, a spokesperson of the CONAIE and a former supreme court judge. In the end, after negotiations between the indigenous movement and the army, the successor of President Mahuad, Gustavo Noboa, assumed power and constitutional order was re-established.

Those events highlighted "the fact that the indigenous movement has taken center stage within this complex array of forces". ${ }^{15}$ Their agenda comprises a broad platform demanding global social justice. According to the United Nations Economic Commission for Latin America and the Caribbean (ECLAC), indigenous peoples are not just calling for more and better democracy, better application of mechanisms for the defence and protection of human rights, or a bigger share in benefits coming from development programs; "they are in fact questioning and challenging the basic premises on which the Nation-state has been built in Latin America for almost two centuries". ${ }^{16}$ Surely this will have an impact when dealing with the issue of representation and voice of vulnerable workers, most of whom (maybe less so in urban areas) are of indigenous origin. More precisely, the hypothesis can be put forward that given indigenous organisations' critical stand on the political, cultural, social and economical institutions, they might chose means other than the formal institutional one to voice their demands.

\footnotetext{
${ }^{14}$ Economist Intelligence Unit, op. cit.

15 COLLINS, Jennifer N. 2000. “A Sense of Possibility. Ecuador's Indigenous Movement Takes Center Stage". Nacla: Report on the Americas. March/April, p. 41.

16 STAVENHAGEN, Rodolfo. 1997. "Indigenous organizations: rising actors in Latin America”. Revista del CEPAL. No 62, p. 65.
} 
These events laid bare the profound legitimacy crisis of Ecuador's political system. ${ }^{17} \mathrm{~A}$ survey conducted at the turn of the century showed that only $7 \%$ of the people expressed confidence in the Congress. The President's popularity obtained a similar rating. A CEDATOS/Gallup poll done in Ecuador in 2001 confirmed the generalized lack of confidence of Ecuadorians in their political system. Indeed, the National government, Congress and political parties received a respective institutional approval of 30.5\%, 24.7\% and $21.4 \%$. The same poll also showed that more local institutions such as neighbourhood associations, municipalities and provincial councils got a much more favourable approval rating of respectively $46.9 \%, 46.7 \%$ and $40.0 \%$. It is at these levels that an important number of indigenous leaders are active. ${ }^{18}$ Thus while national institutions and functions are losing credibility, local political institutions seem to get much more support from the population. This should be borne in mind when dealing with the formulation and implementation of policies directed at vulnerable workers. ${ }^{19}$

Supported by the indigenous' movements (namely the Pachakutic movement), in November 2002 Lucio Gutiérrez won the presidential elections, promoting a social agenda that won broad public support. Soon after, his apparent orthodox stance on economic and social policies became a source of discontent. ${ }^{20}$ The limited number of Pachakutik members ${ }^{21}$ in cabinet posts, the nomination of Gutiérrez's family members and former army colleagues to important positions, and his embracing of conditions set by the International Monetary Fund (IMF) led to a weakening of the link with the coalition of social movements that had brought him to power. The indigenous movement in Ecuador caters for a broad segment of the impoverished population, and "indigenous issues stand at the point of intersection of considerations relating to human rights, democracy, development and environment. It has become increasingly clear that indigenous demands do not concern the indigenous peoples themselves, but involve the whole of national society". ${ }^{22}$ In relation to the mass mobilization that occurs in Ecuador, another analyst refers to the process of "democratic questioning," which refers to "street democracy" in the absence of institutional and efficient democratic institutions allowing for the transmission of social demands. ${ }^{23}$

${ }^{17}$ COLLINS, Jennifer N. 2000. "A Sense of Possibility. Ecuador's Indigenous Movement Takes Center Stage”. Nacla: Report on the Americas. March/April, p. 41.

18 BONNASSIES, Violanie. 2002. Le mouvement indigène en Équateur. Note de recherche 04-01. Montréal : Cahier de recherche CEIM, p. 11.

19 MONTUFAR, César. 2004. "Antipolítica, representación y participación ciudadana” in Ecuador Debate. No 62. August.

${ }^{20}$ Economist Intelligence Unit, op. cit., p. 7.

21 In 1995, the Coordinadora de movimientos sociales formed around the conflict surrounding the oil industry. The basis of this network is three-fold: labour (Central de trabajadores de Ecuador), informal economy operators and church-based associations. In the same year, the political party called Pachakutik-Nuevo Pais was created, in alliances with the Indigenous movement (CONAIE) and some urban sectors. Since 1996, Pachakutik has presented candidates in every election. It was instrumental in bringing Lucio Gutiérrez in 2002.

22 STAVENHAGEN, Rodolfo. 1997. "Indigenous organizations: rising actors in Latin America". Revista del CEPAL. No 62, p. 68.

23 MELO-PINZON, Gladys. 2004. "La identidad y la ciudadanía en América Latina : la resistencia civil y pacífica indígena colombiana bajo el fuego cruzado," in La chronique des Amériques. Observatoire des Amériques. Montréal (Université du Québec à Montréal), No 32. Oct. p. 1. 
This politically volatile climate makes it difficult to elaborate and implement policies adapted to the political, economic and social needs of the country. For the most part of the 1990s, Ecuador was strangled by its political environment, attributable to an insufficient and contradictory handling of public affairs, which was not favourable to human development or improvement in the quality of life of its population. More broadly, all these factors limited the possibility to build solid mechanisms of representation genuinely reflecting the regional, ethnic and gender composition of the society. ${ }^{24}$

\section{Economic}

In March 2000, under President Gustavo Noboa, Ecuador adopted the American dollar as its unique currency, making the country the first in Latin American to eliminate its national currency. It aimed at controlling inflation, which reached $6.1 \%$ in December 2003, a rate comparable to Colombia's but higher than that of other countries in the region. ${ }^{25}$ While dollarization may have contributed to improving Ecuador's position with many international financial institutions, it did not solve the country's persistent economic difficulties.

In 2003, Ecuador's external debt was US \$16 595 billion, up 3 billion from $2000 .{ }^{26}$ The share of the private debt in the global external debt grew rapidly from $16 \%$ to $31 \%$ during the same period. Debt service represented $8,6 \%$ of the country's GDP, a drop from $10.1 \%$ in 1990. In 2001, debt servicing represented $22 \%$ of exported goods and services (down from $31 \%$ in 1990), being one of the $7^{\text {th }}$ worst off countries in Latin America. ${ }^{27}$

The few years before the turn of the millennium were particularly difficult for Ecuador. It had to deal with the repercussions of the border conflict with Peru (1995), the effects of El Niño in 1998, the drastic drop in the price of oil during 1998-1999, and the effects of a financial crisis that started in Asia in 1997 and which resulted in the bankruptcy of many private banks between 1999 and 2001.

Data shows that extreme poverty has not diminished in recent years. About one third of the urban population, $60 \%$ of the rural population and $90 \%$ of the indigenous population live with less than US\$ 2 per day. ${ }^{28}$

${ }^{24}$ ILO. 2003. Análisis de las Políticas y Programas Sociales en Ecuador. Lima. OIT/Oficina Regional para las Américas/Programa IPEC. p. 18.

${ }^{25}$ In this period, Peru had an inflation rate of $2.5 \%$, Colombia $6 \%$, Bolivia $3.3 \%$, Chile $1 \%$ and Mexico 4\%. 2003. Análisis de Conyutura Económica. Quito: ILDIS/Friedrich Ebert Stiftung. p. 69.

${ }^{26}$ ILDIS. 2003. Análisis de Conyutura Económica. Quito: ILDIS/Friedrich Ebert Stiftung. p. 60.

${ }^{27}$ UNDP. 2003. Millennium Development Goals: A compact among nations to end human poverty. NEW York: UNDP, p. 230.

${ }^{28}$ BID. 2002. BID. 2002. Evaluación del Programa de País. Ecuador 1990-2002. Washington: BID/Oficina de Evaluación y Supervisión. del Programa de País. Ecuador 1990-2002. Washington: BID/Oficina de Evaluación y Supervisión. 
According to some, dollarization made the country's products less competitive on the various regional markets and did little to increase the diversification of the national production. Although there was improvement in some economic indicators, they have much to do with the rise in the price of oil, foreign investment related to the construction of the crude oil pipeline, emigration rate and related remittances. ${ }^{29}$

Apart from the remittances sent by Ecuadorians having emigrated, which now amounts to the second most important revenue source for the country, at around 6\% of the GDP (or US\$ 1.4 billion), ${ }^{30}$ Ecuador's economy is mainly dependent on its primary industry. Since the 1970s, oil has been one of the most lucrative sources of export revenues for Ecuador, accounting for $37 \%$ of exports in $2003 .^{31}$ With private companies getting active in the field, Petroecuador, a state enterprise went from a 60\% public capital share in 2000 to $37 \%$ in 2003.

One third of Ecuador's land is used for agricultural purposes. Ecuador's number one agricultural export is bananas, with a total of US\$1.3 billion in 2003, twice as much as the next country, Costa Rica. This industry employs close to 200,000 persons in Ecuador. The other major agricultural exports are shrimp, cocoa, coffee and cut flowers. ${ }^{32}$ Domestic agriculture is characterized by low productivity and soil degradation, fuelling rural to urban migration. This has in turn fed the number of workers finding themselves needing to land an urban, and often not protected, job.

In terms of manufacturing, Ecuador has concentrated on textiles, food and drink, tobacco, oil refining and cement production. Recent trade liberalization has exposed domestic industry to tough competition but has also prompted exports. The Community of Andean Nations trade agreements have opened markets and stimulated other industries, such as chemical, machinery, minerals, paper, printing and wood products, to develop.

\section{Population}

Ecuador ranks 100 (out of 177 countries) on the 2004 UNDP Human Development Index, scoring only better than El Salvador (103), Guyana (104), Bolivia (114), Honduras (115), Nicaragua (118), Guatemala (121), and Haiti (153) amongst Latin American countries. Only a few places ahead of Bolivia (114), Ecuador has the second lowest rating among South American countries.

According to the Instituto Nacional de Estadistica y Censos (INEC), Ecuador's population growth slowed down in the 1990's. In 2001, there were 12.1 million Ecuadorians (12.6 million according to UNDP). In 2003, the World Bank reported 12.8 million living in Ecuador. The growth of the population was slower than had been expected by the United Nations. It is estimated that by 2015, the population of Ecuador should be about 15.2 million.

\footnotetext{
${ }^{29}$ MALDONADO, Carlos Larrea. 2004. Pobreza, dolarización y crisis en el Ecuador. Quito: Abya Yala, p. 69

30 BID. 2002. BID. 2002. Evaluación del Programa de País. Ecuador 1990-2002. Washington: BID/Oficina de Evaluación y Supervisión. Washington: BID/Oficina de Evaluación y Supervisión.

${ }^{31}$ Economist Intelligence Unit, op. cit., p. 39.

${ }^{32}$ ibid.
} 
Indigenous populations in Ecuador represent an important proportion of the population. Estimations vary. According to the World Fact Book, 25\% of the Ecuadorian population is indigenous and a further $65 \%$ is mestizo (mixed). Ecuador is among the Latin American countries with the highest proportion of indigenous peoples. CONAIE's own estimates suggest that $45 \%$ of the country's population is indigenous, and that $70 \%$ are represented by CONAIE. Given diversity among this population, it does not represent a monolithic movement. ${ }^{33}$

The lower than anticipated population growth rate can be explained by a few factors amongst which are the broader use of family planning, the increased participation of women in the labour force, mostly in the vulnerable economy as seen below, and the massive emigration of Ecuadorians looking for jobs outside the country.

It is estimated that between $1998-2000$, more than 200,000 people left the country. In 2001 , more than 500,000 people took the same decision. They are for the most part city dwellers who have been impoverished in the wake of the economic reforms the country has undertaken. Between 1992-2001, migration figures show a net loss of 628,000 people, or $5.2 \%$ of the total population. ${ }^{34}$ These migrants mostly join the vulnerable economy in their countries of destination, with Spain and Italy being two important locations. It had led to an important drop in the unemployment rate which cannot be explained by an economic recovery.

In 2001, 63.4\% of the population lived in urban settings. This proportion is increasing as people are seizing opportunities to improve their living conditions in cities. The proportion of people living in rural areas decreased from $45 \%$ in 1990 to $39 \%$ of the population in 2002. Roughly a third of the population is under the age of 15 . Life expectancy at birth is 70.8 years.

Ecuador spent $1.2 \%$ of its GDP for health care in 2001, which represented US\$ 78 per capita, a little more than what Haiti spends (US\$ 56 per capita). This represented a drop from 1990, when it was $1.5 \%$ of GDP. Between 1998-2001, on average, the country spent $1.6 \%$ of its GDP on education, which represented $8 \%$ of the government's total expenditures, a significant drop from 1990 when education represented respectively $2.8 \%$ of GDP and 17\% of Ecuador's spending. Between 1990 and 2001 the adult literacy rate improved from $87.6 \%$ to $91.8 \%$ of the population over 15 years old. However, military expenditure is on the rise: from a level of $0.2 \%$ of GDP in 1990 to $2.1 \%$ of the nation's GDP in 2001. ${ }^{35}$ Acces to basic services (water, electricity, waste collection, sewer system) has increased by only $7 \%$ since the 1990 s.

${ }^{33}$ World Fact Book: http://www.cia.gov/cia/publications/factbook/geos/ec.html\#People. See also: Van COTT, Donna Lee (ed.). 1995. Indigenous peoples and democracy in Latin America. New York: St Martin's Press in association with The Inter-American Dialogue. For CONAIE's figures, see: Las nacionalidades indigenas en el Ecuador. Nuestro proceso organizativo. Quito: Ediciones Tincui - Abya-Yala. 1989. See also CEPAL/ECLAC Review , No 47, p. 42.

34 BID. 2002. BID. 2002. Evaluación del Programa de País. Ecuador 1990-2002. Washington: BID/Oficina de Evaluación y Supervisión. del Programa de País. Ecuador 1990-2002. Washington: BID/Oficina de Evaluación y Supervisión.

${ }^{35}$ UNDP. 2003. Millennium Development Goals: A compact among nations to end human poverty. NEW York: UNDP 
Levels of poverty are high (see Table 1). According to the Interamerican Development Bank (IADB), since 1999 the number of people living in poverty and extreme poverty situations reached respectively 6.9 million and 2.5 million. This mans that in spite of important migration, 3 million more people now have to face the daily uncertainty of procuring the basic food requirements for their families. ${ }^{36}$ Other sources show that the situation has improved since 2000, but that is not yet sufficient to get back to the pre-1995 situation, as shown in Table 2 below. ${ }^{37}$

Table 1

\% of population living in poverty and extreme poverty 1995-2001

\begin{tabular}{|c|c|c|c|c|c|c|c|c|}
\hline & \multicolumn{4}{|c|}{ Poverty } & \multicolumn{4}{|c|}{ Extreme poverty } \\
\hline & 1995 & 1998 & 2000 & 2001 & 1995 & 1998 & 2000 & 2001 \\
\hline Rural & 75,8 & 82,0 & 84,1 & 77,5 & 33,9 & 46,1 & 58,2 & 50,5 \\
\hline Urban & 42,4 & 48,6 & 60,3 & 51,6 & 10,6 & 13,0 & 30,3 & 24,7 \\
\hline Total & 55,9 & 62,6 & 68,8 & 60,8 & 20,0 & 26,9 & 40,3 & 33,8 \\
\hline
\end{tabular}

Source: INEC-WB, Encuestas de condiciones de vida de 1995 y 1998. INEC, Encuestas EMEDIHNO 2000 and ENEMDUR 2001. Quoted in Carlos Larrea Maldonado. 2004, p. 50

Wealth distribution is quite inequitable. In 2002, the poorest $40 \%$ of the households had access to only $13.8 \%$ of the national income. The Gini coefficient went from 0.46 in 1990 to 0.51 in $2002 .{ }^{38}$

In 2003 , the average nominal wage rose by $8.0 \%$ (US $\$ 158,80$ per month), but the real minimum wage was still $4.6 \%$ below its 1998 level. Even though a tripartite committee responsible for evaluating the minimum wage increased it to US\$ 166.10 per month in 2004, this was still far below the minimum amount needed for a family of four to buy the basic basket of goods, estimated at US\$ 286.75 per month. ${ }^{39}$

According to the Economic Intelligence Unit, the official unemployment rate almost doubled between 1998 and 2000, when it reached 16.1\%. It decreased in the subsequent years due to the construction of major infrastructure projects (crude oil pipeline construction) and by mid 2004 it was estimated at $10.5 \%$, rising again upon completion of major infrastructure work. The underemployment rate is estimated at $43 \%$. The high emigration rate helped keep these numbers "down". Emigration was particularly marked in 2000 and 2001. ${ }^{40}$

Table 2 below, using recent data from INEC, presents some labour market indicators covering the period between 1990 and 2002 for individuals over the age of 10 .

The economic situation of the 1990s has been qualified by many as a situation of increasing erosion of the employment situation. The number of people looking for jobs in urban settings grew more rapidly than the number of jobs being created. In spite of the important emigration of early 2000, the official unemployment rate was higher in 2002

36 BID. 2002. BID. 2002. Evaluación del Programa de País. Ecuador 1990-2002. Washington: BID/Oficina de Evaluación y Supervisión.

37 MALDONADO, Carlos Larrea. 2004. Pobreza, dolarización y crisis en el Ecuador. Quito: Abya Yala, p. 50.

38 ECLAC. 2004. Panorama Social. Santiago de Chile.

39 Economist Intelligence Unit, op. cit., p. 36.

40 ibid. 
than it was in 1990. It is worth noting the important increase in women's participation in active life. The proportion of women working or looking for a job rose from $37.2 \%$ in 1990 to $46.7 \%$ in 2002 , a jump of almost $10 \%$. The proportion of women actually working during that period went up 6.4 per cent.

Unemployment also grew in the twelve year period presented, with a record peak in 1999 where $10.8 \%$ of men and $19.6 \%$ of women were officially unemployed. It is common that women's unemployment rate is higher than the men's, sometimes twice as much, as can be seen in Table 2 below.

Table 2

Employment indicator by sex in urban Ecuador, 1990-2002 $(\%)$

\begin{tabular}{|c|c|c|c|c|c|c|c|c|}
\hline & 1990 & 1994 & 1995 & 1998 & 1999 & 2000 & 2001 & 2002 \\
\hline $\begin{array}{l}\text { Economically active } \\
\text { population }\end{array}$ & 52,2 & 55,6 & 55,7 & 58,4 & 60,0 & 57,3 & 63,1 & 58,3 \\
\hline Men & 68,3 & 70,4 & 70,2 & 71,8 & 73,1 & 70,3 & 74,0 & 70,2 \\
\hline Women & 37,2 & 41,9 & 42,4 & 46,1 & 47,8 & 45,0 & 52,5 & 46,7 \\
\hline Unemployment rate & 6,1 & 7,1 & 6,9 & 11,5 & 14,4 & 9,0 & 10,9 & 9,2 \\
\hline Men & 4,3 & 5,8 & 5,5 & 8,4 & 10,8 & 6,2 & 7,1 & 6,0 \\
\hline Women & 9,1 & 9,3 & 8,8 & 16,0 & 19,6 & 13,1 & 16,2 & 14,0 \\
\hline Employment rate & 49,1 & 51,6 & 51,9 & 51,7 & 51,4 & 52,2 & 56,2 & 52,9 \\
\hline Men & 65,4 & 66,3 & 66,3 & 65,8 & 65,2 & 65,9 & 68,7 & 66,0 \\
\hline Women & 33,8 & 38,0 & 38,6 & 38,8 & 38,5 & 39,1 & 44,0 & 40,2 \\
\hline
\end{tabular}

Source: INEC, various years as processed by Sistema de información y análisis laboral/OIT

As for the type of employment being considered, it is worth noting, in Table 3 below, that "informal" " activity (defined in Ecuador as own account work, domestic employment and as enterprises of fewer than five people) grew as a proportion of total employment, as compared with formal employment. In $1990,55.6 \%$ of the active population was working in informal employment as opposed to $57.4 \%$ twelve years later. Almost $2 \%$ fewer people worked in formal employment in 2002 (42.6\%) than in 1990 (44.4\%). The share of public employment has dropped significantly throughout the period: $6.8 \%$ fewer men and $4.4 \%$ fewer women worked in public administration in 2002 in comparison with 1990.

${ }^{41}$ The term "informal" is the one used by INEC. 
Table 3

Type of (non agricultural) employment by sex in urban Ecuador, 1990-2002 (\%)

\begin{tabular}{|c|c|c|c|c|c|c|c|c|}
\hline & 1990 & 1994 & 1995 & 1998 & 1999 & 2000 & 2001 & 2002 \\
\hline $\begin{array}{l}\text { Global informal } \\
\text { employment * }\end{array}$ & 55,6 & 57,6 & 57,4 & 58,5 & 58,8 & 57,7 & 58,5 & 57,4 \\
\hline "Men & 51,7 & 53,8 & 53,2 & 54,4 & 54,7 & 55,0 & 54,8 & 52,8 \\
\hline $\begin{array}{l}\text { Own account workers } \\
\text { Domestic }\end{array}$ & 32,6 & 29,3 & 29,5 & 28,8 & 27,2 & 31,9 & 28,8 & 29,7 \\
\hline Micro business & $\begin{array}{c}0,7 \\
18,4\end{array}$ & $\begin{array}{c}0,4 \\
24,1\end{array}$ & $\begin{array}{c}0,7 \\
23,1\end{array}$ & $\begin{array}{c}1,0 \\
24,5\end{array}$ & $\begin{array}{c}0,7 \\
26,8\end{array}$ & $\begin{array}{c}0,8 \\
22,2\end{array}$ & $\begin{array}{c}1,0 \\
25,0\end{array}$ & $\begin{array}{c}0,7 \\
22,4\end{array}$ \\
\hline Women & 62,1 & 63,2 & 63,6 & 64,3 & 64,7 & 61,7 & 63,8 & 64,1 \\
\hline $\begin{array}{l}\text { Own account workers } \\
\text { Domestic }\end{array}$ & 39,9 & 38,0 & 39,5 & 38,8 & 36,6 & 38,0 & 39,6 & 39,4 \\
\hline Micro business & $\begin{array}{l}12,1 \\
10,1\end{array}$ & $\begin{array}{l}12,1 \\
13,1\end{array}$ & $\begin{array}{l}11,7 \\
12,5\end{array}$ & $\begin{array}{l}13,1 \\
12,5\end{array}$ & $\begin{array}{l}13,5 \\
14,7\end{array}$ & $\begin{array}{l}11,7 \\
12,0\end{array}$ & $\begin{array}{l}11,3 \\
12,8\end{array}$ & $\begin{array}{l}11,4 \\
13,3\end{array}$ \\
\hline $\begin{array}{l}\text { Global formal } \\
\text { employment }\end{array}$ & 44,4 & 42,4 & 42,6 & 41,5 & 41,2 & 42,3 & 41,5 & 42,6 \\
\hline Men & 48,3 & 46,2 & 46,8 & 45,6 & 45,3 & 45,0 & 45,2 & 47,2 \\
\hline Public sector & 19,0 & 14,5 & 14,1 & 12,2 & 11,2 & 10,9 & 10,1 & 12,2 \\
\hline Private sector ${ }^{\star *}$ & 29,3 & 31,7 & 32,7 & 33,4 & 34,1 & 34,1 & 35,1 & 35,0 \\
\hline Women & 37,9 & 36,8 & 36,4 & 35,7 & 35,3 & 38,3 & 36,2 & 35,9 \\
\hline Public sector & 18,0 & 15,1 & 14,4 & 13,2 & 11,4 & 13,3 & 11,3 & 13,6 \\
\hline Private sector & 19,8 & 21,7 & 22,0 & 22,5 & 23,9 & 25,0 & 25,0 & 22,3 \\
\hline
\end{tabular}

Source: Source: INEC, various years as processed by Sistema de información y análisis laboral/OIT * Including domestic service.

** Small, medium and large sized businesses.

As observed in many studies, women are often found more frequently in the informal economy than men. The difference is quite evident as far as domestic work is concerned. Women, as compared with men, have a noticeably higher participation rate as own account workers but a significantly lower participation rate in micro businesses, defined as economic units of less than 5 people. Women and men have a comparable participation rate in the public sector, which has been consistently decreasing as a share of total formal employment in the twelve years under observation. Private formal employment, defined as small, medium and large sized businesses, has never exceeded $35.1 \%$ of men and $25 \%$ of women.

Social security coverage, or the lack of it, is an important issue for workers in the informal economy and in general for small-scale economic units. These workers are more vulnerable in case of occupational hazards. A healthier and more secure workforce increases productivity. Minimum social security is also a matter of basic human rights. ${ }^{42}$

The data available give an idea of the weak social security coverage of the Ecuadorian population, whether workers are formal or informal. According to the World Bank development indicators, in Latin America, Ecuador has one of the lowest levels of expenditure on health care (one dimension of social security), amounting to a provisional $2.2 \%$ of the country's GDP in 2004. In 1999, the government spent $0.6 \%$ of GDP on health care. The regional Latin American average is $7 \%$ of GDP. ${ }^{43}$

One of the first conclusions that can be drawn from the INEC data available on the social security coverage of Ecuadorian urban workers, i.e. participation in the scheme administered by the Instituto ecuatoriano de seguridad social (IESS), is the low rate and important fluctuation from year to year. This points out the high degree of vulnerability of

42 CHEN, Martha Alter, JHABVALA Renana and LUND, Frances. 2002. Supporting Workers in the Informal Economy: A policy framework. Geneva: ILO. p. 36

43 Economist Intelligence Unit, op. cit., p. 21 
the work force and workers' inability to count on a regular safety net in case of downturns. To give an example, in 1999, $62.3 \%$ of the workers involved in formal activities were covered by the IISE. The following year, that figure dropped to $54.3 \%$.

Overall, social security coverage diminished throughout the period covered (1990-2002). The INEC data available show that in 1990, $72.1 \%$ of formal workers (public and private) benefited from the social security coverage. This figure dropped to $60.8 \%$ in 2002 , before reaching a record low of $54.3 \%$ in 2000 . As could have been expected, social security coverage is better for public sector workers than for those in the private sector. The statistics show that in 1990, $91.9 \%$ of the public sector workers were covered by the insurance scheme as opposed to $57.7 \%$ of the private formal workers. In 2002, the proportion of workers in formal employment in the private sector who were covered by social insurance had dropped to $49.5 \%$.

As far as workers in informal employment is concerned, coverage is even lower than that observed for formal workers, as could have been expected. In 1990, the data show that only $10.8 \%$ of the informal workers (whether own account, micro business or those that did not declare any remuneration, such as home workers, contributed to the IIES. The situation slightly improved during the reference period, to attain $11.5 \%$. For the twelve year period under review, between $79.3 \%$ and $85.2 \%$ of workers in micro enterprises, between $87.8 \%$ and $91.8 \%$ of own-account workers and between $91.4 \%$ and $94.2 \%$ of workers who did not declare any income were not covered by any social security scheme.

Tables 4 (a) and (b) present a more detailed portrait of the social security coverage for men and women in formal and informal urban employment in Ecuador for the period 19902002. The same overall tendency as described above is present, that is to say that apart from public sector workers, social security coverage is low. In fact, in any type of employment (whether it is formal or informal) never more than $56.9 \%$ of men and $59.6 \%$ of women are covered by social security (with the highest coverage rates in the private formal sector).

As far as women and men in formal employment are concerned, the data available shows that women are generally better covered by the social security scheme than men. On average for the 12 years for which data is available, $67.9 \%$ of women workers in formal employment are covered, where as an average of $60.6 \%$ of men in such employment are covered. When looking at informal workers in general, the figures show that the average coverage rate of both men and women throughout the period is comparable: $12.0 \%$ of men in informal employment and $11.7 \%$ of women in informal employment can benefit from the IISE scheme.

Whereas women working in the informal economy have slightly increased their affiliation to the IESS (from 9.9\% in 1990 to $11.6 \%$ in 2002), men's coverage has kept stable at a little over $11 \%$. Women working in micro businesses have seen a 5 point percentage increase in their social security coverage during the twelve years under study, and those working in micro enterprises have increased their coverage by almost $2 \%$. Though it has fluctuated through out the period under observation, the coverage of women in informal employment who did not report any wage earnings stayed steady at $6.1 \%$. 
Table 4 (a)

Social security coverage of men by type of employment in urban Ecuador 1990-2002

(\%)

\begin{tabular}{|c|c|c|c|c|c|c|c|c|}
\hline & 1990 & 1994 & 1995 & 1998 & 1999 & 2000 & 2001 & 2002 \\
\hline $\begin{array}{l}\text { Overall nonagricultural urban } \\
\text { employment } \\
\text { With social security } \\
\text { Without social security }\end{array}$ & $\begin{array}{c}100,0 \% \\
(n=1341 \\
819) \\
39.9 \\
60.1\end{array}$ & $\begin{array}{c}100,0 \% \\
(n=1486 \\
334) \\
37.7 \\
62.3\end{array}$ & $\begin{array}{c}100,0 \% \\
(n=1603 \\
147) \\
36.6 \\
63.4\end{array}$ & $\begin{array}{c}100,0 \% \\
(n=1707 \\
967) \\
34.5 \\
65.5\end{array}$ & $\begin{array}{c}100,0 \% \\
(n=1763 \\
284) \\
33.6 \\
66.4\end{array}$ & $\begin{array}{c}100,0 \% \\
(n=1828 \\
658) \\
28.8 \\
71.2\end{array}$ & $\begin{array}{c}100,0 \% \\
(1971329) \\
32.0 \\
67.8\end{array}$ & $\begin{array}{c}100,0 \% \\
(n=1871 \\
618) \\
33.4 \\
66.6\end{array}$ \\
\hline $\begin{array}{l}\text { Formal sector } \\
\text { With social security } \\
\text { Without social security } \\
\text { Public sector } \\
\text { With social security } \\
\text { Without social security } \\
\text { Private sector } \\
\text { With social security } \\
\text { Without social security }\end{array}$ & $\begin{array}{r}47.5 \\
71.0 \\
29.0 \\
39.4 \\
92.7 \\
7.3 \\
60.6 \\
56.9 \\
43.1 \\
\end{array}$ & $\begin{array}{l}45.9 \\
64.0 \\
36.0 \\
31.3 \\
89.4 \\
10.6 \\
68.7 \\
52.3 \\
47.7 \\
\end{array}$ & $\begin{array}{l}46.7 \\
63.5 \\
36.5 \\
30.2 \\
89.9 \\
10.1 \\
69.8 \\
52.0 \\
48.0\end{array}$ & $\begin{array}{r}45.6 \\
62.4 \\
37.6 \\
26.8 \\
99.6 \\
0.4 \\
73.2 \\
48.8 \\
51.2\end{array}$ & $\begin{array}{r}45.3 \\
59.0 \\
41.0 \\
24.8 \\
98.9 \\
1.1 \\
75.2 \\
45.8 \\
54.2\end{array}$ & $\begin{array}{l}45.0 \\
50.6 \\
49.4 \\
24.2 \\
80.4 \\
19.6 \\
75.8 \\
41.1 \\
58.9\end{array}$ & $\begin{array}{l}44.3 \\
56.5 \\
43.5 \\
22.3 \\
86.6 \\
13.4 \\
77.7 \\
47.8 \\
52.1\end{array}$ & $\begin{array}{l}46.8 \\
57.9 \\
42.1 \\
25.8 \\
87.5 \\
12.5 \\
74.2 \\
47.7 \\
52.3\end{array}$ \\
\hline $\begin{array}{l}\text { Informal sector } \\
\text { With social security } \\
\text { Without social security } \\
\frac{\text { Micro business }}{\text { With social security }} \\
\text { Without social security } \\
\frac{\text { Own account }}{\text { With social security }} \\
\text { Without social security } \\
\frac{\text { Workers without }}{\text { remuneration }} \\
\text { With social security } \\
\text { Without social security }\end{array}$ & $\begin{array}{r}50.1 \\
11.3 \\
88.7 \\
36.2 \\
16.1 \\
83.9 \\
56.4 \\
9.0 \\
91.0 \\
7.5 \\
5.3 \\
94.7 \\
\end{array}$ & $\begin{array}{r}53.1 \\
15.0 \\
85.0 \\
45.2 \\
18.7 \\
81.3 \\
48.4 \\
12.9 \\
87.1 \\
6.5 \\
4.4 \\
95.6 \\
\end{array}$ & $\begin{array}{r}52.4 \\
12.3 \\
87.7 \\
43.9 \\
15.5 \\
84.5 \\
49.2 \\
10.6 \\
89.4 \\
6.9 \\
4.6 \\
95.4\end{array}$ & $\begin{array}{r}53.4 \\
10.7 \\
89.3 \\
46.0 \\
12.6 \\
87.4 \\
\frac{46.4}{9.6} \\
90.4 \\
7.7 \\
6.1 \\
93.9\end{array}$ & $\begin{array}{l}54.0 \\
12.3 \\
87.7 \\
49.7 \\
14.4 \\
85.6 \\
45.1 \\
11.0 \\
89.0 \\
\\
5.2 \\
4.1 \\
95.9\end{array}$ & $\begin{array}{r}54.1 \\
10.7 \\
89.3 \\
41.0 \\
12.9 \\
87.1 \\
53.1 \\
9.5 \\
90.5 \\
5.9 \\
5.1 \\
94.9\end{array}$ & $\begin{array}{r}52.7 \\
12.0 \\
87.6 \\
46.5 \\
14.7 \\
85.2 \\
46.0 \\
10.4 \\
89.2 \\
7.5 \\
5.5 \\
92.8\end{array}$ & $\begin{array}{r}51.7 \\
11.4 \\
88.6 \\
43.0 \\
13.3 \\
86.7 \\
51.7 \\
10.3 \\
89.7 \\
5.3 \\
5.9 \\
94.1\end{array}$ \\
\hline $\begin{array}{l}\text { Domestic services } \\
\text { With social security } \\
\text { Without social security }\end{array}$ & $\begin{array}{r}0.7 \\
20.8 \\
79.2\end{array}$ & $\begin{array}{r}0.4 \\
35.4 \\
64.6\end{array}$ & $\begin{array}{r}0.7 \\
50.8 \\
49.2\end{array}$ & $\begin{array}{r}1.0 \\
33.0 \\
67.0\end{array}$ & $\begin{array}{r}0.7 \\
36.2 \\
63.8\end{array}$ & $\begin{array}{r}0.8 \\
29.8 \\
70.2\end{array}$ & $\begin{array}{r}1.0 \\
28.8 \\
71.2\end{array}$ & $\begin{array}{r}0.7 \\
21.7 \\
78.2\end{array}$ \\
\hline Not classified & 1.7 & 0.7 & 0.2 & 0.0 & 0.0 & 0.0 & 1.9 & 0.8 \\
\hline
\end{tabular}


Table 4 (b)

(\%)

\begin{tabular}{|c|c|c|c|c|c|c|c|c|}
\hline & 1990 & 1994 & 1995 & 1998 & 1999 & 2000 & 2001 & 2002 \\
\hline $\begin{array}{l}\text { Overall nonagricultural urban } \\
\text { employment } \\
\text { With social security } \\
\text { Without social security }\end{array}$ & $\begin{array}{c}100,0 \% \\
(n=806843) \\
35.4 \\
64.6\end{array}$ & $\begin{array}{c}100,0 \% \\
(n=1006 \\
361) \\
35.8 \\
64.2\end{array}$ & $\begin{array}{c}100,0 \% \\
(n=1093 \\
756) \\
35.1 \\
64.9\end{array}$ & $\begin{array}{c}100,0 \% \\
(n=1201 \\
980) \\
33.2 \\
66.8\end{array}$ & $\begin{array}{c}100,0 \% \\
(n=1216 \\
306) \\
32.0 \\
67.9\end{array}$ & $\begin{array}{c}100,0 \% \\
(n=1239 \\
016) \\
30.6 \\
69.4\end{array}$ & $\begin{array}{c}100,0 \% \\
(n=1404 \\
048) \\
30.0 \\
69.9\end{array}$ & $\begin{array}{c}100,0 \% \\
(n=1260 \\
688) \\
31.0 \\
69.0\end{array}$ \\
\hline $\begin{array}{l}\text { Formal sector } \\
\text { With social security } \\
\text { Without social security } \\
\text { Public sector } \\
\text { With social security } \\
\text { Without social security } \\
\text { Private sector } \\
\text { With social security } \\
\text { Without social security }\end{array}$ & $\begin{array}{r}37.4 \\
74.3 \\
25.7 \\
47.6 \\
90.5 \\
9.5 \\
\underline{52.4} \\
59.6 \\
40.4\end{array}$ & $\begin{array}{l}36.7 \\
70.1 \\
29.9 \\
41.1 \\
88.4 \\
11.6 \\
58.9 \\
57.3 \\
42.7\end{array}$ & $\begin{array}{l}36.4 \\
70.8 \\
29.2 \\
39.6 \\
87.9 \\
12.1 \\
60.4 \\
59.6 \\
40.4\end{array}$ & $\begin{array}{r}35.7 \\
70.7 \\
29.3 \\
36.9 \\
99.0 \\
1.0 \\
63.1 \\
54.1 \\
45.9\end{array}$ & $\begin{array}{r}35.3 \\
68.4 \\
31.5 \\
32.3 \\
98.1 \\
1.9 \\
67.7 \\
54.2 \\
45.6\end{array}$ & $\begin{array}{l}38.3 \\
60.8 \\
39.2 \\
34.8 \\
79.5 \\
20.5 \\
65.2 \\
50.9 \\
49.1\end{array}$ & $\begin{array}{l}35.5 \\
61.7 \\
38.3 \\
31.1 \\
81.4 \\
18.6 \\
68.9 \\
52.9 \\
47.1\end{array}$ & $\begin{array}{l}35.7 \\
66.4 \\
33.6 \\
37.9 \\
87.3 \\
12.7 \\
\underline{62.1} \\
53.7 \\
46.3\end{array}$ \\
\hline $\begin{array}{l}\text { Informal sector } \\
\text { With social security } \\
\text { Without social security } \\
\text { Micro business } \\
\text { With social security } \\
\text { Without social security } \\
\frac{\text { Own account }}{\text { With social security }} \\
\text { Without social security } \\
\frac{\text { Workers without }}{\text { remuneration }} \\
\text { With social security } \\
\text { Without social security }\end{array}$ & $\begin{array}{r}49.4 \\
9.9 \\
90.1 \\
20.2 \\
22.6 \\
77.4 \\
57.6 \\
6.9 \\
93.1 \\
22.2 \\
6.1 \\
93.9\end{array}$ & $\begin{array}{l}51.0 \\
14.6 \\
85.4 \\
25.7 \\
26.1 \\
73.9 \\
\underline{53.5} \\
10.8 \\
89.2 \\
20.8 \\
10.3 \\
89.7\end{array}$ & $\begin{array}{r}51.9 \\
12.7 \\
87.3 \\
24.0 \\
23.0 \\
77.0 \\
\frac{52.4}{9.7} \\
90.3 \\
\frac{23.6}{9.0} \\
91.0\end{array}$ & $\begin{array}{r}51.3 \\
10.7 \\
89.3 \\
24.4 \\
21.1 \\
78.9 \\
\frac{55.0}{7.7} \\
92.3 \\
\frac{20.6}{6.3} \\
93.7\end{array}$ & $\begin{array}{r}51.3 \\
11.6 \\
88.4 \\
\frac{28.7}{22.0} \\
78.0 \\
\frac{52.6}{7.3} \\
92.7 \\
\frac{18.7}{7.6} \\
92.4\end{array}$ & $\begin{array}{r}50.1 \\
11.1 \\
88.9 \\
24.0 \\
20.4 \\
79.6 \\
\frac{57.0}{7.8} \\
92.2 \\
\frac{19.0}{9.0} \\
91.0\end{array}$ & $\begin{array}{r}51.3 \\
11.5 \\
88.3 \\
\frac{24.5}{19.1} \\
80.9 \\
\frac{58.6}{9.9} \\
90.0 \\
\frac{16.9}{6.2} \\
93.2\end{array}$ & $\begin{array}{r}52.4 \\
11.6 \\
88.4 \\
25.2 \\
21.0 \\
79.0 \\
\frac{59.5}{9.0} \\
91.0 \\
\frac{15.3}{6.1} \\
93.9\end{array}$ \\
\hline $\begin{array}{l}\text { Domestic services } \\
\text { With social security } \\
\text { Without social security }\end{array}$ & $\begin{array}{l}\mathbf{1 1 . 9} \\
17.6 \\
82.4\end{array}$ & $\begin{array}{l}12.1 \\
21.2 \\
78.8\end{array}$ & $\begin{array}{l}11.6 \\
22.8 \\
77.2\end{array}$ & $\begin{array}{l}13.1 \\
19.0 \\
81.0\end{array}$ & $\begin{array}{l}13.5 \\
14.8 \\
85.2\end{array}$ & $\begin{array}{l}11.7 \\
15.5 \\
84.5\end{array}$ & $\begin{array}{l}\mathbf{1 1 . 1} \\
15.4 \\
84.6\end{array}$ & $\begin{array}{r}11.3 \\
8.7 \\
91.3\end{array}$ \\
\hline Not classified & 1.2 & 0.2 & 0.1 & 0.0 & 0.0 & 0.0 & 2.1 & 0.6 \\
\hline
\end{tabular}

Source: INEC, various years as processed by Sistema de información y análisis laboral/OIT 
In 2001, INEC tried asking the informants in its Encuesta de empleo urbano (survey of urban employment) about their ethnic origin. The experience was repeated in 2002. The data is presented below. Ecuador, like Bolivia, Peru and Guatemala, has an indigenous population estimated at around $40 \%$.

The results in Table 5 should be interpreted with caution, even though scarce information on ethnicity, gender and type of enterprise is welcome. The Ecuadorian survey called for self-identification of ethnic origin by the respondents. This may explain the noticeable differences between 2001 and 2002. To give an example, in 2001, 19\% of the population surveyed said they were white and $72 \%$ rather said they were mestizos. In 2002, those numbers were respectively $9 \%$ and $84 \%$. That is to say that between the two surveys, a significant number of people changed their opinion on their ethnic identity. (An alternative explanation would relate to the migration patterns.)

In the Tables below, the rather small proportion of indigenous people can be explained by the fact that the survey deals with urban inhabitants. The vast majority of indigenous people lives in rural areas.

Furthermore, the data presented below cannot be directly compared with the information above (Tables), for only people over the age of 15 (as opposed to age 10 in the Tables above) were asked to specify their ethnic identity.

One last precaution in drawing conclusions pertains to the small number of people surveyed. In 2001 for instance, there were 105,596 indigenous people involved in non agriculture related activities. In 2002, there were 67,687. When data is broken down into formal and informal employment, and then into persons with or without social security, the number of respondents in each category might not be sufficient for definite conclusions to be drawn.

Nonetheless, the data points to some interesting trends. Based on the figures presented in Tables B (i) and B (ii) in the Annex, Table 5 presents the propensity of each ethnic group to be represented in formal and informal employment. ${ }^{44}$

Table 5

Propensity by ethnic group to be represented in different employment categories 2001-2002

\begin{tabular}{|c|c|c|c|c|c|c|}
\hline \multirow{2}{*}{$\begin{array}{c}\text { Type } \\
\text { of } \\
\text { employment }\end{array}$} & \multicolumn{6}{|c|}{2001} \\
\hline & White & Indigenous & Mestizo & Black & Mulato & Other \\
\hline Formal & 1,15 & 0,96 & 0,97 & 1,19 & 0,60 & - \\
\hline Informal & 0,92 & 1,04 & 1,03 & 0,73 & 1,07 & - \\
\hline Domestic & 0,74 & 2,61 & 0,94 & 2,04 & 1,53 & - \\
\hline Not classified & 1,00 & 0,51 & 1,02 & 1,41 & 0,58 & - \\
\hline
\end{tabular}

\begin{tabular}{|c|c|c|c|c|c|c|}
\hline \multirow{2}{*}{$\begin{array}{c}\text { Type } \\
\text { of } \\
\text { employment }\end{array}$} & \multicolumn{6}{|c|}{2002} \\
\hline & White & Indigenous & Mestizo & Black & Mulato & Others \\
\hline Formal & 1,17 & 0,69 & 0,99 & 0,86 & 0,98 & 1,29 \\
\hline Informal & 0,82 & 1,35 & 1,02 & 0,89 & 0,85 & 1,05 \\
\hline Domestic & 0,80 & 1,50 & 0,91 & 2,92 & 2,39 & 0,0 \\
\hline Not classified & 0,46 & 0,00 & 0,98 & 1,80 & 6,25 & 0,0 \\
\hline
\end{tabular}

Source: INEC, various years as processed by Sistema de información y análisis laboral/OIT 44 The propensity score is an estimate of the probability that an observed phenomenon in a segment
of the population would be found in another segment of the population. 
From the figures presented in Table 5 and Tables B (i) and (ii), it can be concluded for 2001 that while $19.1 \%$ of the urban population over the age of 15 declared itself to be of white ethnicity, they occupied $22.0 \%$ of the formal non agricultural urban jobs in the country (in 2002: $8.5 \%$ and $10.0 \%$ respectively). In both cases, this indicates an overrepresentation of whites in formal employment of respectively $15 \%$ and $17 \%$, given that a perfect proportionality would be equivalent to 1.00 . Consequently, the data shows that white people have less chance to end up in informal or domestic employment, as could have been expected.

In 2001, indigenous peoples represented $3 \%$ of the urban population and their share of the formal urban employment was $2.9 \%$ (in $2002: 2.1 \%$ and $1.4 \%$ respectively). If ideally the ratio of population to formal economy participation would be again equivalent to 1.00 , indigenous people were therefore slightly underrepresented in $2001(0.96)$ and more so in the subsequent year (0.69), bearing in mind the cavats presented above. The indigenous population is overrepresented in informal and domestic employment, as showed in Table 5.

In the first year under study, mestizos amounted to $72.1 \%$ of the population, and they constituted $70.0 \%$ of urban formal employment (in 2002: $84.6 \%$ and $84.1 \%$ respectively). For both years, mestizos were slightly underrepresented in formal and domestic employment and slightly overrepresented in informal employment.

In 2001, black people accounted for $2.8 \%$ of the urban population of more than 15 years of age. Of these, $3.4 \%$ worked in a formal setting, being strongly overrepresented in this category of employment (1.19). This is not the case for the following year however; in 2002 , they represented $3.4 \%$ of the urban population, but they occupied only $3.0 \%$ of formal employment, being underrepresented (0.89). ${ }^{45}$ In both years, black people were underrepresented in informal employment $(0.73$ and 0.89$)$ and highly overrepresented in domestic employment (2.04 and 2.92).

Finally, in 2001, 3.0\% of the population surveyed declared being mulatto, and they occupied $1.8 \%$ of the formal urban jobs, showing the highest underrepresentation observed (0.6). In 2002, they represented $1.1 \%$ of the urban population of 15 years and up, and they had a quasi proportionate participation rate in the formal economy (0.98). They seem to be strongly overrepresented in domestic employment (1.53 in 2001 and 2.39 in 2002).

Table 6 below presents the propensity of each ethnic group to benefit from social security or not, in relation to the type of employment.

Looking at the formal economy for the year 2001, and keeping in mind the precautions set out earlier as to sample size, it can be seen that white people (1.29) have the highest chance to benefit from social security coverage, while the other ethnic groups all have a lower than 1.0 propensity. Mulatos are the least susceptible ethnic group in terms of social security coverage. The same trend can be observed within the informal economy: white people having a higher propensity to be covered by social security (1.15), with black people being the worst off (0.34). The same conclusion can be drawn from the 2002 data presented in Table 7. Whether informal or formal workers are concerned, white people seem to have a better access to social security coverage.

\footnotetext{
45 This variation is important, and cannot be further explained at this point by the fact that the survey data is based on self- identification.
} 
Looking more closely at the formal economy and its two contexts, private and public, it can again be seen that white people have an advantageous position. There is a higher possibility that they will be covered by social security. ${ }^{46}$ White people were in the same advantageous situation in 2002 .

In 2001, although black people were overrepresented in formal employment (1.20 for the public sector and 1.19 for the private sector), in both cases, they are strongly likely to work without social security (2.09 in the public and 1.75 in the private sector). As already pointed out, the situation was quite different in 2002: black people were less represented in public employment (0.82) and private formal employment (0.91). In both situations, however, though, they were overrepresented among those who do not benefit from social security coverage ( 1.53 for the public sector and 1.17 for the private sector).

${ }^{46}$ For some affirmative action may exist, so caution should be used in interpreting the data. 
Table 6

Propensity of ethnic group to be represented in various types of employment, with or without social security.

\begin{tabular}{|c|c|c|c|c|c|c|c|c|c|c|c|}
\hline & \multicolumn{5}{|c|}{2001} & \multicolumn{6}{|c|}{2002} \\
\hline & indigenous & White & Mestizo & Black & Mulato & indigenous & White & mestizo & Black & Mulato & Others \\
\hline POPULATION OF 15 YEARS AND UP & & & & & & & & & & & \\
\hline Not economically active & 0,87 & 1,06 & 0,99 & 0,89 & 1,18 & 0,74 & 1,13 & 1.00 & 0,86 & 0,82 & 0,92 \\
\hline Economically active & 1,05 & 0,97 & 1,01 & 1,05 & 0,92 & 1,13 & 0,93 & 1.00 & 1,07 & 1,09 & 1,02 \\
\hline Unemployed & 0,87 & 0,80 & 1,05 & 1,22 & 1,02 & 0,65 & 0,81 & 1.00 & 1,42 & 1,63 & 0,48 \\
\hline Employed & 1,07 & 1,00 & 1,00 & 1,03 & 0,91 & 1,17 & 0,95 & 1.00 & 1,04 & 1,04 & 1,07 \\
\hline Agriculture (including mines) & 0,99 & 0,88 & 1,01 & 1,28 & 1,18 & 2,29 & 0,76 & 0.97 & 1,47 & 1,24 & 0,84 \\
\hline Not agriculture & 1,08 & 1,01 & 1,00 & 1,00 & 0,89 & 1,06 & 0,96 & 1.00 & 0,99 & 1,02 & 1,10 \\
\hline With social security & 0,82 & 1,25 & 0,97 & 0,70 & 0,55 & 0,52 & 1,33 & 0.99 & 0,72 & 0,88 & 1,71 \\
\hline Without social security & 1,20 & 0,89 & 1,01 & 1,15 & 1,05 & 1,33 & 0,79 & 1.01 & 1,13 & 1,08 & 0,80 \\
\hline Formal sector & 0,96 & 1,15 & 0,97 & 1,19 & 0,60 & 0,69 & 1,17 & 0.99 & 0,89 & 0,98 & 1,29 \\
\hline With social security & 0,75 & 1,29 & 0,96 & 0,78 & 0,53 & 0,53 & 1,34 & 0.99 & 0,68 & 0,97 & 1,70 \\
\hline Without social security & 1,26 & 0,95 & 0,98 & 1,79 & 0,70 & 0,93 & 0,91 & 1.00 & 1,20 & 0,99 & 0,65 \\
\hline$\underline{\text { Public sector }}$ & $\underline{0,78}$ & $\underline{1,10}$ & $\underline{0,99}$ & $\underline{1,20}$ & $\underline{0,61}$ & $\underline{0,48}$ & $\underline{1,13}$ & $\underline{1.00}$ & $\underline{0,82}$ & $\underline{1,39}$ & $\underline{2,56}$ \\
\hline With social security & 0,83 & 1,10 & 1,00 & 1,04 & 0,55 & 0,41 & 1,14 & 1.00 & 0,71 & 1,30 & 2,93 \\
\hline Without social security & 0,49 & 1,13 & 0,95 & 2,09 & 0,88 & 0,96 & 1,11 & 0.96 & 1,53 & 2,05 & 0,00 \\
\hline Private sector & $\underline{1,02}$ & $\underline{1,17}$ & $\underline{0,96}$ & $\underline{1,19}$ & $\underline{0,60}$ & $\underline{0,77}$ & $\underline{1,19}$ & $\underline{0.99}$ & $\underline{0,91}$ & $\underline{0,80}$ & $\underline{0,75}$ \\
\hline With social security & 0,70 & 1,40 & 0,94 & 0,62 & 0,52 & 0,61 & 1,49 & 0.98 & 0,66 & 0,73 & 0,77 \\
\hline Without social security & 1,35 & 0,93 & 0,99 & 1,76 & 0,68 & 0,93 & 0,89 & 1.01 & 1,17 & 0,88 & 0,72 \\
\hline Informal sector & 1,04 & 0,92 & 1,03 & 0,73 & 1,07 & 1,35 & 0,82 & 1.02 & 0,89 & 0,85 & 1,05 \\
\hline With social security & 0,98 & 1,15 & 1,01 & 0,34 & 0,45 & 0,55 & 1,34 & 0.99 & 0,77 & 0,21 & 1,97 \\
\hline Without social security & 1,05 & 0,89 & 1,03 & 0,79 & 1,15 & 1,45 & 0,75 & 1.02 & 0,91 & 0,93 & 0,93 \\
\hline$\underline{\text { Micro business }}$ & $\underline{1,18}$ & $\underline{0,92}$ & $\underline{1,03}$ & $\underline{0,72}$ & $\underline{0,89}$ & $\underline{0,80}$ & $\underline{0,85}$ & $\underline{1.02}$ & $\underline{0,96}$ & $\underline{0,84}$ & $\underline{1,21}$ \\
\hline With social security & 1,05 & 1,23 & 0,98 & 0,28 & 0,56 & 0,72 & 1,44 & 0.98 & 0,89 & 0,44 & 0,00 \\
\hline Without social security & 1,21 & 0,86 & 1,04 & 0,81 & 0,96 & 0,82 & 0,74 & 1.03 & 0,98 & 0,91 & 1,43 \\
\hline$\underline{\text { Own account }}$ & $\underline{0,96}$ & $\underline{0,90}$ & $\underline{1,03}$ & $\underline{0,80}$ & $\underline{1,21}$ & $\underline{1,64}$ & $\underline{0,82}$ & $\underline{1.01}$ & $\underline{0,88}$ & $\underline{0,89}$ & $\underline{1,11}$ \\
\hline With social security & 0,89 & 1,07 & 1,04 & 0,46 & 0,21 & 0,37 & 1,26 & 1.00 & 0,74 & 0,00 & 4,20 \\
\hline Without social security & 0,97 & 0,89 & 1,02 & 0,84 & 1,32 & 1,78 & 0,78 & 1.01 & 0,89 & 0,99 & 0,78 \\
\hline Workers without remuneration & $\underline{0,93}$ & $\underline{1,00}$ & $\underline{1,03}$ & $\underline{0,42}$ & $\underline{0,97}$ & $\underline{1,77}$ & $\underline{0,62}$ & $\underline{1.04}$ & $\underline{0,65}$ & $\underline{0,59}$ & $\underline{0,00}$ \\
\hline With social security & 1,09 & 1,07 & 1,00 & 0,00 & 1,39 & 0,59 & 1,19 & 1.05 & 0,00 & 0,00 & 0,00 \\
\hline Without social security & 0,93 & 1,01 & 1,02 & 0,46 & 0,95 & 1,86 & 0,58 & 1.04 & 0,70 & 0,64 & 0,00 \\
\hline
\end{tabular}




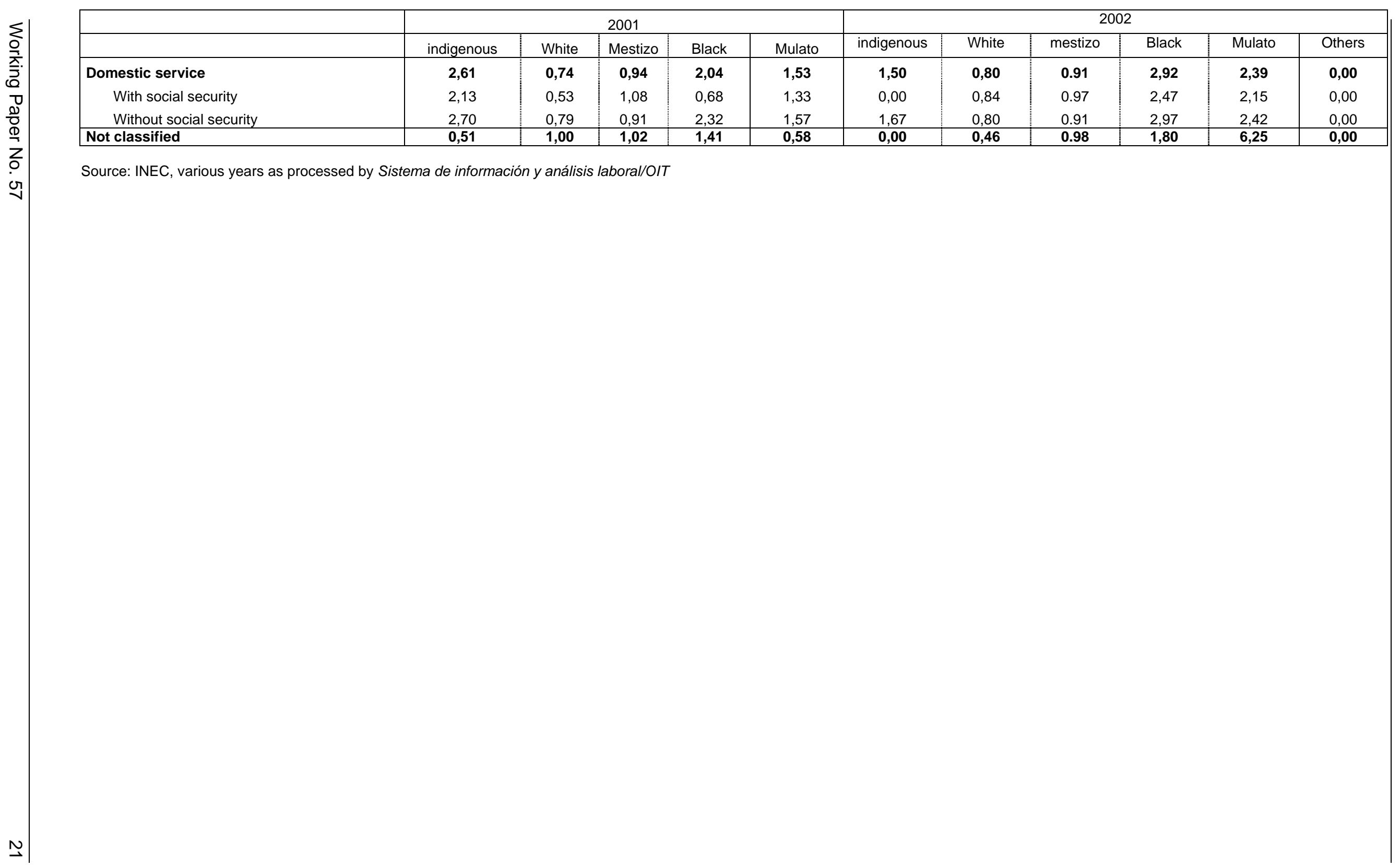


As far as indigenous people are concerned, the data presented in Table 6, and for 2001, shows that they are more likely to be represented in the private sector formal employment (1.02) than in the public sector $(0.78)$. Within the private sector, indigenous people are overrepresented among those without social security coverage (1.35). It has already been noted for 2002 that indigenous people are overtly underrepresented in the formal labour market (0.69). They also seem less likely to be affiliated to social security schemes.

Leaving aside formal employment and looking more closely at the informal economy, Table 6 shows that in 2001, indigenous (1.04), mestizo (1.03) and mulato (1.07) workers are more likely to be in the informal economy than white people (0.92) and than black people (0.73), and they are also more likely to be without social security coverage. Though underrepresented in informal employment, white people are overrepresented among those benefiting from social security coverage, whether in micro enterprises (1.23), own account workers (1.07) or those without reportable income (10.7).

In 2002, indigenous workers in the informal economy were strongly represented among those who did not benefit from social security (1.45). This translates into a higher incidence of non protected indigenous workers in own account employment (1.78) and among those without reportable income (1.86).

Mestizos, though less evidently than it is the case for indigenous people, also tend to be overrepresented among informal workers without social security coverage. The same remark can be made for mulatos.

\section{Informal economy: taking into account the changing times}

An "informal" job has often been defined as a job that does not fulfil the requirements of what is associated with a "formal" job: a fairly stable wage job, for one employer, with a variable amount of social protection and rights associated to it, for most of the working life of the worker. This pattern of what constitutes a "formal", desirable job is quite recent. In industrialized countries, it has not been a common concept for much more than a century. In industrialized countries, it has been the result of a compromise, through an institutionalized process of social dialogue, between organized labour, employers and governments to insure a certain redistribution of wealth in a way that would guarantee a relative decent quality of life for the majority and a certain degree of social peace for all.

In the context of globalization, the increasing number of workers throughout the world drifting away from this pattern might put into question the relevance of the concept of a "normal job" or a "formal job" as the cornerstone of the architecture of other labour rights and as the means to social justice. Ecuador is a case in point.

It has already been pointed out that the proportion of non agricultural informal workers grew in Ecuador from $55.6 \%$ in 1990 to $57.4 \%$ in 2002. ${ }^{47}$ Moreover, in the case of Ecuador, taking social security coverage as an indicator of decent work, Table 4(a) shows that as far as formal employment is concerned, male workers in the public and the private formal sectors have seen their social security coverage diminish between 1990 and 2002. In the case of public sector workers, the number of people not being covered by any social security schemes went up from $7.3 \%$ in 1990 to $12.5 \%$ in 2002 . These are workers who are said to be in the best possible employment situation, working for the public sector,

${ }^{47}$ INEC. 2002. Encuesta Periodica de Empleo y Desempleo en el Area Urbana and Encuesta de Empleo Urbano. 
where one would hope that a minimum level of social security coverage would exist. In the case of the formal private sector, the proportion of male workers not covered by social insurance grew 9.2 point of percentage during the same period. The trends for women are similar. "These trends suggest that the restructuring of capitalist accumulation in the past decade is progressively erasing the boundaries between formal and informal activity". ${ }^{48}$

There is recognition by some that the current global context allows for a different reading of the informal economy. Some authors such as Juan Diego Trejos and Juan Pablo Pérez refer to these new globalization related trends as "neo-informality." ${ }^{49}$ The trends date back to the early 1980 s, when a shift in the labour market occurred that made it more difficult to distinguish between what had traditionally been called formal and informal.

For some in developing countries, the distinction made between regulated and unregulated activities is confronted more and more with the deregulation of the labour market which is, in turn, a consequence of the structural adjustment programmes that have been implemented for some time now. Whether in developing countries or in developed economies, the trend is now toward more heterogeneous, flexible patterns which may be a symptom of the decline of the formal, "normal" or regulated employment relationship. Increasing diversification of the labour market means that increased diversity in the active labour market - more women, more migrant workers, more part-time workers, more people outside paid employment - puts pressure on the representative bodies to reflect these groups' priorities, which may not always be the same as the sole full-breadwinner who was traditionally seen as the "typical" worker". ${ }^{50}$ Research suggests segmentation in relation to types of work: some wage earners work in very precarious conditions, while some selfemployed workers enjoy relatively favourable conditions. ${ }^{51}$ "There is no simple relationship between working in the informal economy and being poor or working in the formal economy and escaping poverty." ${ }^{52}$ As a matter of fact, an increasing number of men and women, in order to complement a loss in their real wage in a formal job, are sometimes forced to be active in an informal job as well.

In parallel, the relationship between capital and labour, if it has been useful in distinguishing between formal and informal economy, might have lost some of its importance now that the introduction of new technologies into small scale economic units can make them quite productive under certain circumstances. Today, technological changes no longer necessarily relate to the size of the economic unit. This is a far cry from the Fordist model of production based on large scale, mass production. That might not be

48 VILAS, Carlos. 1999. "The Decline of the Steady Job in Latin America" in NACLA: Report on the Americas. Vol XXXII. No 4. January-February, p. 15.

49 TREJOS, Juan Diego. 2001. La microempresa de los 90 en Ecuador. Quito : CEPESIU. 91p. And PEREZ, Juan Pablo Pérez. "Neoinformalidad e identidades laborales en centroamerica" in CASTRO, Nadya A et DEDECCA, Claudio. 1998. A occupaçao na America Latina: tempos mais duros. Sao Paulo: Alas, pp. 107-136.

50 TREBILCOCK, Anne. 1994. "Tripartite consultation and cooperation in national-level economic and social policy-making: an overview" in TREBILCOCK, Anne et al., Toward social dialogue: Tripartite cooperation in national economic and social policy making. Geneva: ILO, p. 45.

51 GARZA, Enrique de la and PRIES, Ludger. 1997. "Work, Workers and Social Change in Latin America" in Current sociology. Vol 45, No 1. January, p. 94.

52 ILO. 2002. Women and Men in the Informal Economy: A Statistical picture. Geneva: ILO/Employment sector, p. 14. 
relevant to understanding present production systems. ${ }^{53}$ Small scale business, mostly in the service sector, often catering to governments that have downsized their bureaucracy (for example, printing shops, editorial services, etc.), might well be of reduced size (and perhaps informal), but highly productive. Though these new small, technologically advanced and high-performance micro and small scale enterprises may not be the norm, they constitute a phenomenon that needs to be taken into account in trying to discriminate between formal and informal employment.

Finally, a third phenomenon contributes to the necessity to reassess the utility of the concept of formal, normal labour relation as it has been conceived for the past century or so. Globalization and the increasing interdependency between economic units, whether in the same country or between countries, have shown the many links between formal and informal activities. It is harder to argue now that the formal and informal economy are two distinct phenomena. On the contrary, they are both players in the same global production scheme. In the context of globalization, there is a real need to identify disguised "new" labour relations that hide a "formal" employment relationship on the basis of which workers might be able to get their rights recognized. For those workers who are not in a dependent labour relationship, whether official or disguised, there is a need to find a new principle allowing for social protection and other rights.

In the case of Ecuador, what has been called "terciarización" 54 of the labour force has had, according to the organizations interviewed, quite an important, and negative impact, on labour conditions. It materialized around the proclamation of Bill 133.

The Unión General de Trabajadores del Ecuador (UGTE) is one of those concerned with the new situation being put into place:

\begin{abstract}
Labour flexibility was said to be what Ecuador needed to be competitive in the new global economy. In fact, all it did was to take away workers' rights. This flexibility was not turned into productivity or competitiveness. Products made in Ecuador (because of dollarization) are more expensive than those produced in neighbouring countries. There is a need to look at the informal economy on the basis of contractual relationships. "Terciarización" is just a way to escape the contractual relationship. In the textile industry, for example, each department of an enterprise is an independent business. Since you need 30 workers to form a union, the right to organize is directly affected by this situation.
\end{abstract}

The Central ecuatoriana de organizaciones clasistas unitarias del Ecuador (CEDOCUT) share the same vision:

They (the workers whose work was globally sourced) have a right to stability, a decent wage, social security, and the right to organize. They have to be recognized like all other workers. The minimum would be to grant them the right to organize.

53 PEREZ, Juan Pablo. "Neoinformalidad e identidades laborales en centroamerica" in CASTRO, Nadya A et DEDECCA, Claudio. 1998. A occupaçao na America Latina: tempos mais duros. Sao Paulo: Alas, pp. 109 and CEPESIU. La Microempresa de los 90 en Ecuador. Quito: CEPESIU, p 34.

${ }^{54}$ This term refers to work through the provision of services through third parties, under service contracts, thus avoiding an employer-employee relationship. 
The Central ecuatoriana de organizaciones sindicales libres (CEOSL) expresses the same opinion. In Ecuador, one of the manifestations of these new globalization trends is seen in the increasing use by large companies of subcontracting part of their production to micro and small scale enterprises. It is becoming easier to hide what could be treated as a formal and traditional employment relationship that would be subject to the Ecuador Labour Code. The workers concerned by these working arrangements, according to the CEOLS, should have access to all the protections guaranteed by this law. As the respondent for the CEOSL noted:

Where micro businesses create a dependant wage relationship between the owner and the workers, including where services have been outsourced, these services are not part of the informal economy (for they maintain a dependant relationship vis-à-vis employers). It is very important to define this dependant relationship. It is the key issue. If this is not done, these workers, because they are not legally considered to be employees, are not guaranteed any protection under the Labour Code. And then, there is a further need to define, for the other workers, what kind of social protection to which they should be entitled.

A more in-depth look at new labour relationship is needed. ${ }^{55}$ Invoking government's role in the flexibilization of the labour market, the Centro de promoción de la mujer explains that:

There is a legitimation of informality established now, as a new form of labour that has taken shape in the light of outsourcing practices and flexibilization of working conditions.

A further element has been pointed out by other organizations interviewed in this study. In the context of Ecuador, the people working for the Sistema Integrado de Indicadores Sociales de Ecuador (SIISE) have noticed that a growing formal employment rate has been recently coupled by an equal growth rate in the informal economy. This phenomenon is explained by the increased demand from the people in the formal sector for cheaper goods produced in the informal economy. The "absorption" of vulnerable workers into formal employment as the economy grows seems therefore not very likely.

The relevance of the "normal" job pattern deriving from the dream of eternal prosperity seems to be fading away, and with it the idea of extending it to all. If the extension of this normal job pattern was the arrangement that the social partners (government, employers' and workers' organizations) could reach to ensure decent work and wealth redistribution in the hope of attaining social justice, recent trends might point to a need to find alternative means to the same goal.

The issues of wealth redistribution, decent quality of life and work, poverty elimination and social justice for the majority of workers are as relevant as ever, if not more. But the mechanism devised to insure those rights, at least for the past century, seems to no longer be adequate. The statistics presented above show that even workers that have a formal job have decreasing access to social security. "The idea of employment as the means which permits a living to be earned - an institution which permits one to attain minimal levels of

55 ILO. 1999. Les syndicats et le secteur informel: Pour une stratégie globale. Colloque international sur l'organisation des travailleurs du secteur non structuré. Genève : ILO/ACTRAV. 18-22 octobre. p. 19 
well-being and a sense of efficacy and dignity - is now diluted by the evidence that having a job does not necessarily permit one to live better". ${ }^{56}$ This has been made visible by the increasing number of "working poor" in developed and less developed countries. ${ }^{57} \mathrm{Can}$ therefore becoming an employee be the unique voucher insuring the access to minimum standards of living?

Given the contribution of vulnerable and unprotected workers to the GDP ${ }^{58}$ of their respective countries, these workers, in the author's view, should be granted some access to, at least, social protection. In addition to the human rights dimension of social security coverage, a healthier and more secure work force has a positive impact on productivity levels. Many are thus advocating for a pro-active governmental role in this regard. ${ }^{59}$

The reflections above suggest that there might be a need to look at social justice and its various aspects in a different light in view of the changing global context. There might be a need to go beyond the concepts that allowed us to grasp the reality of the world we were living in, to find new handle on this new reality of the $\mathrm{XXI}^{\text {th }}$ century. As such, it can be asked whether the concepts of "formal" and "informal" are still the most relevant.

The use of a certain terminology (far from being neutral), if it is not adequate, can contribute to hiding the reality it is supposed to describe and complicate the formulation of policies. ${ }^{60}$ The central goal of the ILO, the promotion of social justice and peace, remains more than ever relevant to addressing the problem that "the imbalance between the economy and society is subverting social justice," in the words of the World Commission on the Social Dimension of Globalization. ${ }^{61}$ Addressing these issues on the basis of decent work deficits or on the alleviation of poverty might be more promising for the attainment of common goals than focussing on the concepts of formality and informality, since they no longer seem to discriminate between those who are in a "good" employment situation and those who are not. Given the increasing number of people losing what has been called formal employment, how rational can be the development of a model that would only incorporate a diminishing number of workers?

In the light of the recent changing social, political and economic relations in the wake of globalization and new communication technologies, the reduced relevance of the concept of "normal" employment has been a concern in some industrialized countries that have lived "the dream". Many, as recently noted in the report of the World Commission on the

56 VILAS. Carlos. 1999. "The Decline of the Steady Job in Latin America” in NACLA: Report on the Americas. January-February. p. 20.

57 CHEN, Martha Alter, JHABVALA, Renana and LUND, Frances. 2002. Supporting Workers in the Informal Economy: A policy framework. Geneva: ILO. p. 12

58 Though referring to situations in Africa and Asia, Jacques Charmes (quoted in CHEN et al., op.cit.p. 13) estimates that "in Sub-Saharan Africa, the informal sector contributes anywhere from 7 percent to 59 percent of non-agricultural GDP (...) In Asia, the share of the informal economy ranges from 17 to $48 \%$ of non-agricultural GDP."

59 ILO. 1999. Les syndicats et le secteur informel: Pour une stratégie globale. Colloque international sur l'organisation des travailleurs du secteur non structuré. Genève : ILO/ACTRAV. 18-22 octobre. p. 37

${ }^{60}$ MORENO CORNEJO, Alberto. 2000. Economía popular y desarrollo humano. Quito: AbyaYala. p.9

61 ILO. 2004. A fair globalization: Creating opportunities for all. Report of the World Commission on the Social Dimension of Globalization. Geneva: ILO. p. 3. 
Social Dimension of Globalization, are "concerned with the loss of jobs as a result of industrial restructuring in the face of competitive global markets, and the downward pressures on conditions of work and workers' rights - in Europe and North America as well as in middle-income and transition countries." 62

In the case of developing countries and specifically in the case of Latin America, as illustrated by Ecuador, this "dream" might exactly only have been that, a dream, lived by a small number of workers. ${ }^{63}$ Formal employment has never represented the "norm" that it was supposed to be. In Latin America, as was observed earlier, the formal-normal wage labour relationship has not ever been relevant for more than $50 \%$ of the population. This observation should raise questions about the relevance of the "formal/informal" categories in describing and understanding the labour situation in many developing countries. Some authors thus characterize such a conceptualization of the labour market as ethnocentric and inadequate. "Latin American capitalism has changed, and popular and working class strategies that cannot recognize these changes are condemned to failure and to the reproduction of an unjust social order". ${ }^{64}$

If the formal/informal analytical grid does not seem to be the construct for understanding the social and economic realities of a growing number of countries and workers, the need to address decent work deficits, increasing level of poverty, and more generally social justice, is very much needed.

The lack of representation and voice of these vulnerable workers is certainly one important deficit. This is critical for the respect of an array of other rights and, more generally for participation in the building of democratic and inclusive societies. The following section intends to look at this issue.

Firstly, a statistical model is presented that has been developed by some relevant informal economy actors in Ecuador, incorporating representation and voice as an issue. This model goes beyond the formal/informal dichotomy and uses the concept of low productivity to identify workers and economic units in need of public support to nourish their creativity and entrepreneurship. Then, the issue of voice (used here in terms of organization) and representation (used here to denote participation) of "informal" economy or vulnerable workers and their organizations in the context of the Ecuadorian society is addressed. The results of interviews carried out with relevant informal economy actors are presented.

\section{Representation and voice: Increasing the statistical visibility of vulnerable workers}

In the context of this "neo-informality", the usual criteria used to identify informal workers might not be sufficient to give visibility to those workers, formal or not, who are in need of public policies to address decent work deficits and high levels of poverty. This way of characterizing urban labour market as "formal" or "informal" dates back to many years. The fact that a worker is not protected by social security, participate in an economic unit of (usually) fewer than five people (the Latin American approach), and/or is not legally

62 ILO. 2004. A Fair Globalization: Creating opportunities for all, Report of the World Commission on the Social Dimension of Globalization. Geneva: ILO, p. 13.

63 CHEN, Marta Alter, Renana JHABVALA and Frances LUND. 2002. Supporting Workers in the Informal Economy: A policy framework. Geneva: ILO, p. 7.

${ }^{64}$ VILAS. Carlos. 1999. "The Decline of the steady job in Latin America" in NACLA: Report on the Americas. January-February, p. 20. 
recognized might not be the central factor for identifying who might need positive public action.

Although the many dimensions covered by the definition of informal enterprises and employment yield valuable information on the phenomenon (see introduction), the portrait they paint is still diffuse. They do not offer a clear picture of the reality, or suggest what to do about it in the light of new global production patterns. The complexity of defining the informal economy was addressed in these terms by one member of the Central Ecuatoriana de Organizaciones sindicales libres (CEOLS):

We have to recognize one thing: It is, for example, that domestic workers have working conditions that are distinct from other workers: their conditions are worse in terms of wages, working time, etc. Artisans as well have distinct working conditions. This is true, too, for other informal workers. The problem is how to define with some degree of precision the activities that are really informal and for which these workers should get special attention. It is a somewhat complicated question.

The Federación de Comerciantes Minoristas expressed a similar idea:

There is informality not only in the poorest strata of the country, but in the middle class as well. There is a need for a real look at informality. What about street vendors who buy from bigger businesses and sell on the streets without any dependency relationship to the macro distributor. The owners of a newspaper for example don't themselves sell the newspapers. ... There is a chain of responsibility in the commercialization of a product that should be taken into account.

As explored above the formal/informal paradigm might not be that useful to grasp the actual reality of Ecuador. With informality growing, even workers who have a formal job are losing social protection, and the apparent distinction between formal and informal economy seems to be getting more diffuse. There is a need to find another concept that will allow a more operational look at society.

The concept of "low productivity" might be useful to identify those in need of targeted public policies, whether the economic actor (worker or enterprise) is "informal" or not. Productivity is retained as a basic concept because increasing it along with the quality of the services provided and products produced by vulnerable workers and units is a vital issue that paves the way to sustainable and long term development. ${ }^{65}$

In the case of Ecuador, CEPESIU, the Centro de Promoción y Empleo para el Sector Informal Urbano in 2001 published an interesting mapping of the urban informal sector. It took as a point of departure this concept of low productivity instead of using only the traditional informal economy indicators mentioned above. ${ }^{66}$ It offers an innovative, though not simple, insight into the urban informal economic units/job observed in urban Ecuador, going beyond the general term of "informal" economy, which does not allow a clear sociological understanding of the reality at stake. A sociological look at the phenomenon,

65 CORNEJO, Alberto MORENO. 2000. Economía popular y desarrollo humano. Quito: Abya Yala. p. 104.

${ }^{66}$ CEPESIU. 2001. La micro empresa de los 90 en Ecuador. Quito : CEPESIU, 91 p. 
examining why, in the first place, informality became such an important issue - that is to say the many decent work deficits faced by the workers - might be fruitful in helping vulnerable economic actors and policymakers to elaborate an adequate legal framework that would be most beneficial.

Another organization contacted in this investigation, the Sistema Integrado de Indicadores sociales (SIISE) suggests looking at informality using some other indicators in order to get a more precise picture of what is at stake. The presence, or not, of a separate accountability system at firm level, the affiliation or not to social security, and the type of labour contract were mentioned. Martha Chen et al., taking into account the evaluation of WIEGO (Women in the Informal Employment Globalizing and Organizing), also advocates changes in terms of the definition of the informal economy. ${ }^{67}$

The objective in presenting this model is not to propose a panacea, a "one size fits all" statistical approach to the "informal" economy. It is rather to present the work of one locally involved actor in the domain (the SIISE), therefore giving indirect voice to informal actors, with a view to going beyond simplistic views. Indicators other than wages could be used to capture low productivity. The internal organization of the economic unit, type of contract of the workers, etc. could be useful. The SIISE approach provides an insightful look at a refined analysis of the structure of the urban labour market in Ecuador.

Focussing on the level of productivity, the model makes formalization a means for moving towards decent work and recognition of fundamental labour rights. Many studies have pointed out that while formalization is often the suggested course of action by many governments in dealing with international financing institutions, in practice this does not work. ${ }^{68}$ As expressed by the SIISE, there is a need to know what exactly is eventually to be formalized. Is it the contractual employment relationship? Social protection coverage? How is a business registered at the local but not the national level to be categorized? How to deal with municipalities that collect taxes, but do not allow registration or allow registration but do not provide any type of services? The Fundación Yerbabuena that took part in this study expressed that idea:

People are not informal because they want to be. People simply don't formalize because they do not see any advantages in doing so.

There are two sides to formalization, as explained by the representative of the Federación Ecuatoriana de Indios (FEI):

Formalization is twofold. On the one hand, there is the duty aspect: taxation and then other legal requirements. But then also, there is the rights aspect: being given access to health care, education, credit. The State is so clear when it comes down to competitiveness: businesses need to compete with this and that. But when it comes down to the incorporation of informal workers, there is not a single, clear discourse.

67 CHEN, Martha Alter, Renana JHABVALA and Frances LUND. 2002. Supporting Workers in the Informal Economy: A policy framework. Geneva: ILO, p.5

68 ILO. 1999. Les syndicats et le secteur informel: Pour une stratégie globale. Colloque international sur l'organisation des travailleurs du secteur non structuré. Genève : ILO/ACTRAV. 18-22 octobre, p. 31. 
As stated by many authors, "a higher degree of formalization is desirable only if it leads to greater welfare for micro-entrepreneurs. The formalization of the informal economy should therefore be a consequence of increased advantages of being formal. This of course, calls on all level of government to put forward good governance measures." ${ }^{69}$ As we will see below, and specifically in the case of Ecuador, good governance is a key element in raising the voice and representation of vulnerable workers.

The proposed model incorporates many variables. Firstly, it discriminates between agricultural or non agricultural activities. The urban/rural divide has often been mixed up with the separation between agricultural and non-agricultural activities. The association between rural and agricultural is becoming less accurate as there is an increasing importance of aspects of urbanization in some rural areas and as an increasing number of urban inhabitants who develop some agricultural activities. The focus here is to concentrate on urban and non-agricultural workers.

As far as urban activities are concerned, the distinction that needs to be made is between the "modern" economic sector (where a distinction can be made between private and public sectors) and the low productivity sector, which includes what is identified as economic units with "extended accumulation", "simple accumulation" and those allowing only "subsistence" of the people involved. The Table below offers more detailed description of each of these strata. Modern activities are understood to require an important financial (for example: wholesale activities), physical (for example: electricity and water distribution) and human capital (for example: professionals). These activities also correspond to those where many legal requirements are in place (for example: the medical profession). This categorization is based on the Clasificación industrial Internacional Uniforme de Todas las Actividades Económicas of Ecuador. Table 7 below presents these characteristics in a concise way.

Table 7

\section{Characteristics of modern and low productivity strata}

\begin{tabular}{|c|c|c|}
\hline Type & Stratification & Characteristics \\
\hline \multicolumn{2}{|l|}{ Modern } & $\begin{array}{l}\text { - Can generate important surplus } \\
\text { - Workers are qualified and specialized } \\
\text { - Remuneration is adequate }\end{array}$ \\
\hline \multirow[t]{3}{*}{ Low productivity } & $\begin{array}{l}\text { Extended } \\
\text { accumulation }\end{array}$ & $\begin{array}{l}\text { - Can generate surplus, but in a moderate way } \\
\text { - Workers are qualified and specialized } \\
\text { - Remuneration corresponds to minimum wage }\end{array}$ \\
\hline & Basic accumulation & $\begin{array}{l}\text { - Little capacity to generate surplus } \\
\text { - Few workers are qualified } \\
\text { - Remuneration is low }\end{array}$ \\
\hline & Subsistence & $\begin{array}{l}\text { - Cannot generate surplus } \\
\text { - Workers are unqualified } \\
\text { - Remuneration cannot be more than legal } \\
\text { minimum }\end{array}$ \\
\hline
\end{tabular}

Further, all of those characteristics are then divided according to the size of the economic unit: these are divided into own-account, micro and small economic units and domestic services. Micro business is understood as an economic unit with 5 or fewer workers. Small-scale enterprises offer employment to between 5 and 20 workers.

Finally, the whole architecture of this model relies on the occupational category prevailing in the worker's main job. This will allow, whether in the modern or low productivity

69 ZUIN, Valentina. Business strategies of informal micro-entrepreneurs in Lima, Peru., Geneva: International Institute for Labour Studies. Decent Work Research Programme. DP 150/2004, p. 25. 
sectors, the identification of (1) independent workers: owners of micro or small businesses and own account workers, on the one side and on the other hand (2) dependant workers who can be again found in the modern or low productivity sectors.

One last indicator that will allow this complex structure to come together is the minimum wage which is paid (or not) to the workers. The equivalent of the minimum wage (MW) is being used to distinguish between economic units characterized by subsistence, simple and extended accumulation. The minimum wage is used as opposed to poverty line because the first relates to the opportunity cost of the worker, while the second refers only to the satisfaction of the basic needs of the family members, without regard to the real remuneration of the labour force. ${ }^{70}$ As such, less than one minimum wage per worker corresponds to the subsistence strata. Between one and two minimum wages per worker would be sufficient to qualify as basic accumulation. To reach the extended accumulation strata would require workers to get at least two and less than four minimum wages. And an income of four or more minimum wages would describe the modern strata of the productive structure.

Table 8 below presents this architecture in a concise way.

70 The model presented should be taken with some caveats, since the information collected on the declared wages of workers in many countries, as in Ecuador, is often undervalued and because there in the surveys, only a few questions have been asked to identify in which type of economic units workers are involved. 
Table 8

Stratification of small scale activities

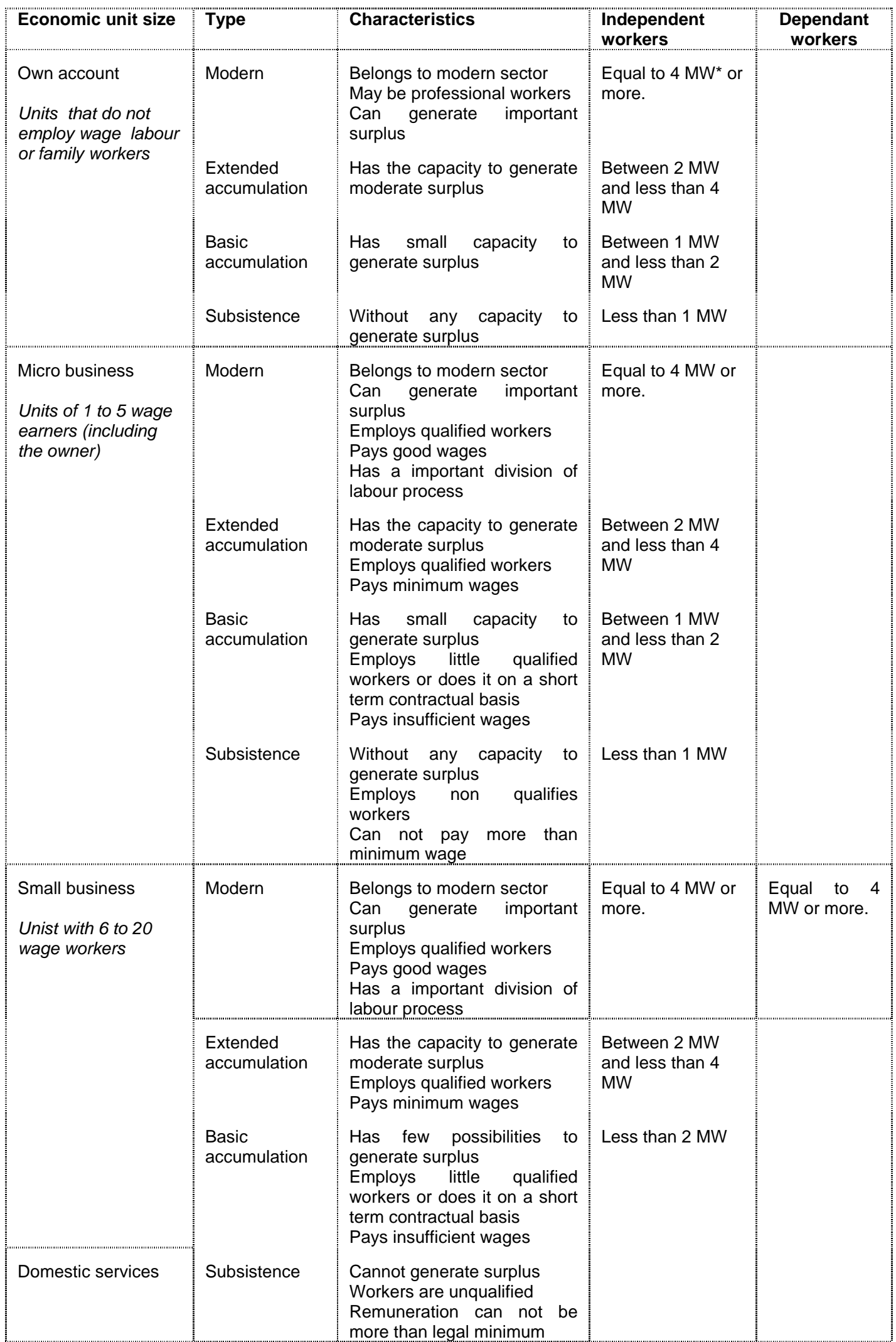

Source: TREJOS, Juan Diego. 2001. La microempresa de los 90 en Ecuador. Quito : CEPESIU.

* MW= Minimum wage 
Once all those variables are taken into account, it becomes possible to draw a portrait of the production structure of Ecuador, allowing a deeper look at vulnerable workers and economic units, identifying those for whom public policies should be drawn. The percentages presented in Figure 1 are based on 1998 data collected by the Instituto Nacional de Estadísticas y Censos (INEC) and by the Pontífica Universidad Católica de Ecuador (PUCE), which collects data for the Banco Central de Ecuador. ${ }^{71}$

Even though dating back to 1998, the numbers presented in the figure below are indicative of the current situation on Ecuador. They show that $81 \%$ of non-agricultural employment is in the private sector. Most of the jobs (61\%) could be classified under either ownaccount work $(31 \%)$, micro business $(18 \%)$ or small business $(12 \%)$. From the Figure it can also be observed that $25 \%$ of those small scale jobs would be qualified as allowing for subsistence, $13 \%$ would have been incorporated into the basic accumulation strata, $6 \%$ into the extended accumulation category, while $14 \%$ of the jobs classified under ownaccount, micro and small businesses would have been said to pertain to the modern strata of the economy.

71 The INEC data come from the Encuesta periódica de Empleo, Subempleo y Desempleo Urbano (periodic survey of urban employment, underemployement and unemployment) and from the PUCE, the Encuesta del Mercado Laboral Ecuatoriano (Ecuadorain Labour Force Survey). 
Figure 1

Structure of the labour market according to segment, size and productive strata
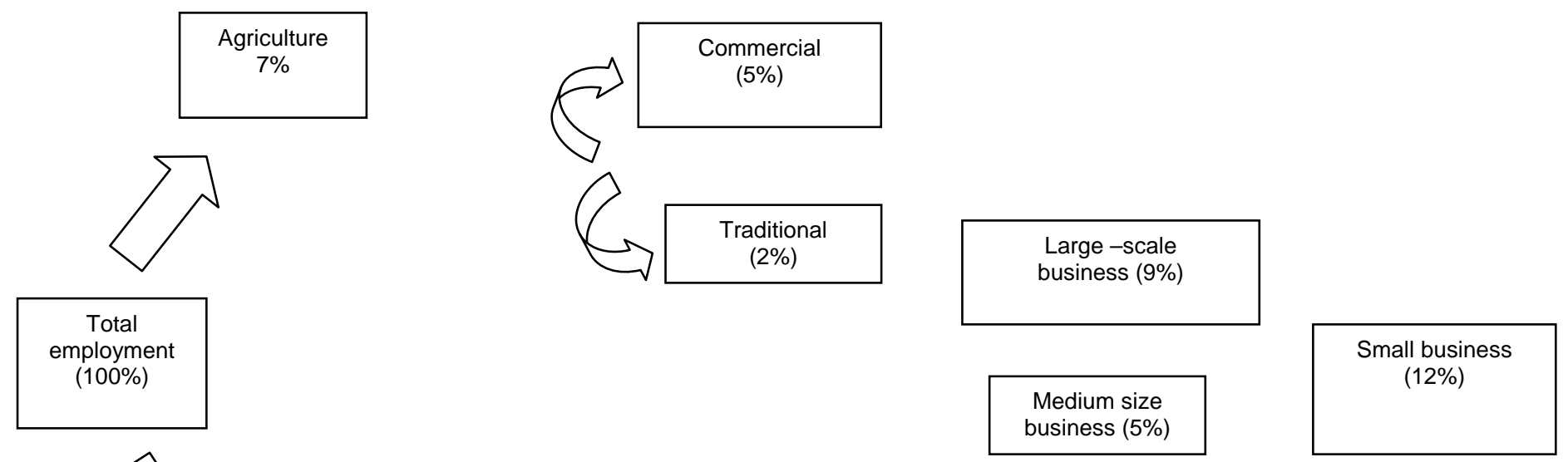

employment

(100\%)
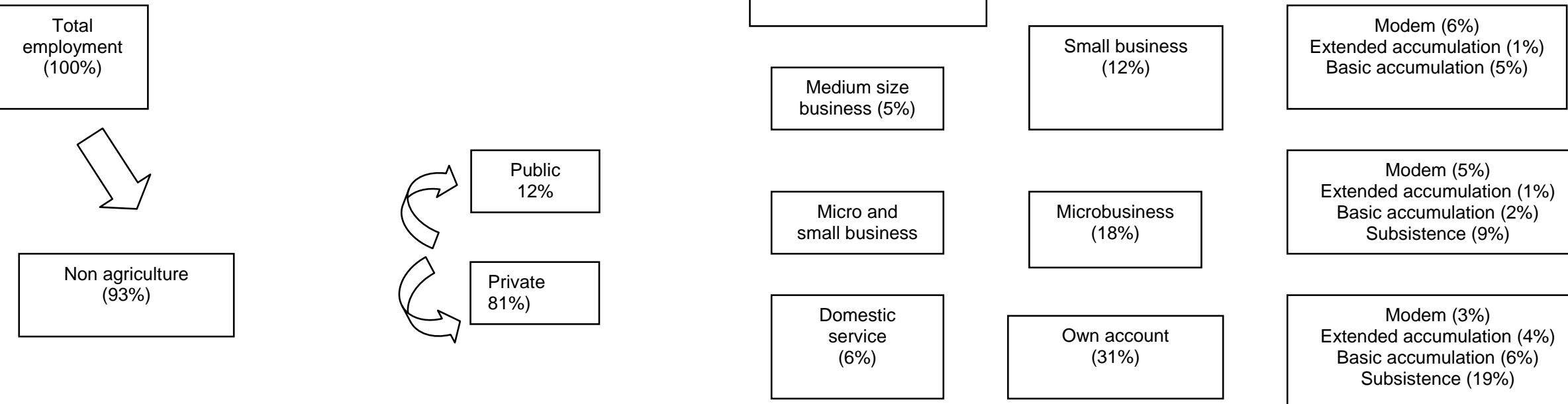

Note: Base on data from Innstituto Nacional de Estadísticas y Censos (INEC) AND THE Pontífica Universidad Católica de Ecuador (PUCE), 1998.

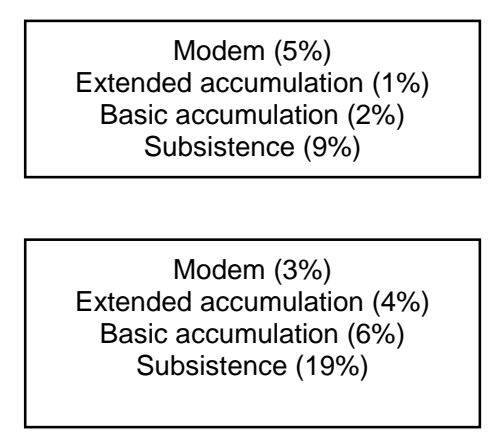


Though complex, the model has some merits. The first is to avoid an automatic association between micro production and informality. As such, it allows a more refined stratification of what is going on as far as vulnerable workers/economic units are concerned, identifying, for example, in the micro businesses or own account group (usually only classified in the informal sector) the different levels of vulnerability. Within the micro business for example, some have an extended accumulation pattern, that might therefore not need sustained public interventions, or a different type of public intervention. This is in contrast to micro business characterized with incomes barely sufficient to cover the basic necessities of the people involved in order to guarantee their long-term activity. In the first case, some public policies directed at sustaining production might be adequate, whereas in the other case, poverty alleviation policies might be better adapted.

In parallel, the model shows some own account and micro business (usually systematically included in the informal sector), located in the modern sector, for which none or a different type of public support might be needed. The qualitative differences between a selfemployed person or a micro business being active in the modern sector of the economy and others being active in the low productivity sector might entail different public policies. As opposed to a traditional definition of a formal/informal approach, this model allows such differences to be taken into account.

The model presented identifies vulnerable workers and economic units in a way different from the traditional informal view of the productive system, which uses informality to include all those working in small scale establishments with low physical capital as well as owners or own-account workers. ${ }^{72}$ We believe that the model provides a more operational look at vulnerable workers than the definitions that have been provided in the introduction to this paper. Considering the globalization trends outlined earlier in this paper, namely the development of what some have called neoinformality, this might prove to be a useful way to address the issue of decent work deficits for increasingly vulnerable workers.

As noted in the Final report of the Committee on the Informal Economy of the $90^{\text {th }}$ ILO Conference, in June $2002^{73}$, the lack of statistical data regarding the informal economy usually means that there is little adequate and accurate labour market information available for the development of effective policies (para. 56). Statistical information on the informal economy is critical in order for any adequate policy and institutional framework aimed at reducing decent work deficits for the workers concerned (paras. 25 and 103). Several Government members of this Committee of the International Labour Conference considered that deeper research, data collection and analysis were necessary to determine the causes and effects of activities in the informal economy, and that the ILO should disseminate the results of this work (para. 163).

Identifying those concerned by the growing phenomenon of the informal economy is without a doubt a preliminary step. A statistical approach to the informal economy that would combine an enterprise-based definition and a focus on individual workers might be more appropriate to the ILO, as suggested by the Committee. At that Conference, a call was made for better statistics and research that would clarify the size and nature of dependent employment in the informal economy (para. 100). In the end, it was recommended that the ILO "assist member States to collect, analyse and disseminate consistent, disaggregated statistics on the size, composition and contribution of the informal economy that will help enable identification of specific groups of workers and

72 CEPESIU. 2001. La micro empresa de los 90 en Ecuador. Quito : CEPESIU, p. 33

73 ILO. 2002. Final report of the Committee on Decent Work and the Informal Economy, International Labour Conference, $90^{\text {th }}$ Session, Geneva, Provisional Record No. 25, June. 
economic units and their problems in the informal economy and that will inform the formulation of appropriate policies and programmes". The model presented above tried to address some of the major concerns of the ILO's constituents as far as developing an accurate, comprehensive and useful statistical approach to vulnerable, mostly informal, workers.

\section{Representation and voice of vulnerable workers}

The issue of representation and voice of informal or vulnerable workers is one of the most important challenges they face. Indeed, it is believed that organization, along with advocacy of these workers' concerns, is one of the first steps towards addressing the many decent work deficits they are facing. While these two aspects are often considered together, the author thinks it best to separate the issues of organization of vulnerable workers from that of voicing their concerns. The relationship between the two is not necessarily direct.

In this section, we intend to first look at the organizational situation of vulnerable workers in Ecuador. They seem to have a certain degree of organization, but while somehow organized, vulnerable workers still face many hardships and do not necessarily enjoy conditions of decent work. The interviews conducted in this study have suggested that the representation of vulnerable workers might be shifting from strictly labour-centred organizations (such as trade unions and associations geared to vulnerable workers) to organizations that embrace a wider social agenda that includes labour issues. In the case of Ecuador, the CONAIE, an indigenous-focussed organization, exemplifies an organization that has developed a broad analysis of the current economic situation, presented it, and won important popular identification with its platform.

Further, we address the extent to which vulnerable workers' concerns are reflected in formal democratic institutions, such as those set up for purposes of social dialogue. While most of the actors interviewed in this study believe in social dialogue as a mean to voice their concerns, many saw shortcomings in the way it operates the process, with impediments for some to participate fully in the processes. The important political presence of the indigenous movement in Ecuador, coupled with the distrust of formal democratic institutions mentioned in the first part of this paper, might have led to a search for other space or fora for their concerns to be voiced. This hypothesis will be addressed in this section.

\section{Organisation of vulnerable workers}

Freedom of association and the right to organize is one of fundamental labour rights. Since the founding of the ILO, it has been one of the most vigorously promoted and defended labour rights. Its universal nature was confirmed in 1998 with the adoption of the Declaration on Fundamental Principles and Rights at Work. The right to form an organization and hence the eventual capacity to participate in various democratic and dialogue processes is the prerequisite for workers' asserting recognition of many more rights. In Ecuador, Bill 133 increased from 15 to 30 the minimum number of workers needed to form a union. As explained by many of the organizations interviewed, this seems to be a serious impediment to the right to organize, making the issue of freedom of association an important one in Ecuador. As recognised by the International Labour Conference in 2002, "the overall challenge is to create a climate in the formal as well as in the informal economies which enables free organization and where those engaged in it can 
act without fear of negative consequences". ${ }^{74}$ The literature on the matter is quite abundant. $^{75}$

For many reasons, vulnerable workers are usually not as well organized as those in the formal economy may be. Recognizing vulnerable workers' right to organize and supporting their endeavours, through unionization or other expressions of freedom of association, is an important step toward increasing workers' capacity to voice their concerns and demands.

In the case of Ecuador, a certain degree of organization among the vulnerable workers was observed in the study. While this investigation does not pretend to have done a systematic survey of all such organizations, quite a number of them seem to exist (see list in Annex A). Indigenous people in Ecuador, for instance, are well organized, ${ }^{76}$ yet the majority face decent work deficits. However, they might not be organized under the rubric of "informality," but rather under the broader claim of social justice.

Given the lack of legal economic and social protections of vulnerable workers, the question arises as to how these workers can best increase their organizational and representational potential. Through unionization? Through other autonomous organizations? Through employers' organizations insofar as micro and small scale economic units are concerned? Through other types of associations?

The World Labour Report 1997-1998 asked "whether there is scope and need for the two traditional actors in industrial relations, namely the employers' organizations and trade unions, to extend their activities to cover informal sector issues". ${ }^{77}$ Or, in the case of Ecuador, is informality still a meaningful concept around which to mobilize? Do vulnerable workers now tend to regroup around some other, broader issues that would not relate immediately to identification in terms of labour per se? These possible scenarios are evaluated below.

\section{Organizing vulnerable workers through trade unions}

In developed economies, trade unions have played a central role, first in promoting workers' and civil rights, and later on playing an important role in the restructuring of economies. Trade unions' role in society has not been confined to the workplace or directed only at labour issues. Historically, trade unions have promoted social justice in a broader sense -- advocating health care, social protection, environmental protection and other issues that are of concern not only to their immediate membership but also to citizens at large. The experiences of trade unions working with other social actors in formulating broader social demands are well documented. ${ }^{78}$

${ }^{74}$ ILO. 2002. Decent work and the informal economy. Geneva: ILC/90 ${ }^{\text {th }}$ Session/Report VI., p. 72.

75 See e.g. TREBILCOCK, A., Decent work and the informal economy: international labour standards, in ILO: Hommages à Nicolas Valticos (ILO, Geneva, 2004), pp. xxx .

${ }^{76}$ It is said that about $40 \%$ of the population is Indigenous and that the CONAIE only represent more than $70 \%$ of the Indigenous population of the country.

77 ILO. 1998. World Labour Report 1997-1998. p. 176

78 ILO. 1999. Les syndicats et le secteur informel: Pour une stratégie globale. Colloque international sur l'organisation des travailleurs du secteur non structuré. Genève : ILO/ACTRAV. 18-22 octobre. p. 52. 
However, in some less industrialized countries, labour market institutions -- and trade unions in particular -- have not had the opportunity to develop their potential strength. In some of these countries, trade union strength lay mostly in the public sector, which became a problem with the shrinking of the State in the 1980s. The consequences of structural adjustment programmes, namely the privatization of important sectors of the public administration, caused much erosion in union membership. As Thomas Henk explains, "the ceremonial side of collective bargaining, whether or not in the form of corporatist state controls, may still be there but any nominal wage increases are more than neutralized by subsequent inflationary pressures. Instead of benefits, trade unions receive messages of retrenchment, reductions in tenured employment and worsening contractual conditions". ${ }^{79}$

The consequences of these economic policies gave rise to a growing informal sector as well as to changes in the formal sector that increased the number of workers not covered by labour protection (as shown in Tables 4(a) and 4(b) above). In all cases, the situation did little to enhance representation through trade unions. "The idea of belonging to a group of fellow-workers - a class - is brought into question by fragmentation. The sentiment of solidarity with fellow workers is undermined by the competition of all against all for a decent job" ${ }^{80}$ According to the CEPESIU, the Corporación de estudios para el sector informal, fragmentation (or the existence of many different organizations) has been identified as an impediment to the effective organization of this informal "sector" as a whole. This situation is reflected in too many unions not being able to coordinate their action to influence government policies. ${ }^{81}$ It is suggested that fragmentation among trade unions is a more important factor than competition from organizations of vulnerable workers.

Many reasons may explain why the growing number of workers in the informal economy has not been able to organize. The report to the 2002 International Labour Conference, Decent work and the informal economy, presents some reasons for the difficulties encountered by unions in wanting to organize informal workers:

- informal economy workers do not represent a uniform group and may have obvious differences of interests among themselves;

- they may not share common interests with the bulk of current union members. Ethnic, family and kinship ties may be stronger among such workers than working class solidarity;

- they are often so caught up in the daily struggle for survival that they are not inclined to join in collective action, especially when they cannot see how such action or membership in a trade union can help them solve their practical problems and basic needs;

- the highly precarious nature of their work means that they are often too worried about losing their jobs to join a union;

79 HENK, Thomas. 1995. "The erosion of Trade Unions" in Globalization and Third World Trade Unions. The Challenge of Rapid Economic Change. London and New Jersey: Zed books, p. 15.

${ }^{80}$ VILAS. Carlos. 1999. "The Decline of the Steady Job in Latin America" in NACLA: Report on the Americas. January-February. p. 20.

81 ILO. 1999. Les syndicats et le secteur informel: Pour une stratégie globale. Colloque international sur l'organisation des travailleurs du secteur non structuré. Genève : ILO/ACTRAV. 18-22 octobre. p. 55 (also available in English and Spanish). 
- importantly, there are often legal barriers to trade union organizing in the informal economy;

- it may be hard for unions to contact and mobilize informal workers, especially home-based workers and those in micro-enterprises - organizing drives can be costly and difficult, as well as time- and resource consuming;

- unions may find it hard to retain such workers as members because of the precarious nature of their employment, and would therefore have to consider whether it is an efficient use of their human and financial resources to try to organize such workers;

- many unions do not have tested strategies for organizing them;

- current union members may not see the rationale for organizing such workers and may object to the necessary changes in policies and resource allocation required to reach out to such workers. The challenge is for the unions to reach out to new groups without undermining their traditional support base. ${ }^{82}$

The lack of organization in the vulnerable economic sector is also due to the particularities of this sector as such. It is often the case that "in the informal sector, remuneration, conditions of work, employment and income opportunities are not, unlike the formal sector, a matter for negotiation with an employer but depend on a variety of actors; operators in this sector are obliged to be in constant contact with market institutions, local authorities, suppliers and contractors" ${ }^{83}$. The informal economy is indeed mainly comprised of non-wage workers, and traditional industrial relationships have been mostly based on wage-earning workers. On top of that, their employment situation may change rapidly - from a street vendor one day to a micro-entrepreneur the next.

The following section presents the viewpoint of vulnerable workers' association and trade unions on the possibilities of organizing vulnerable workers into trade unions.

\section{The viewpoint of vulnerable workers' associations}

The Federación Provincial de Trabajadores del Guayas points out that vulnerable workers are in fact always in "action," and "engaged in the struggle," which may mean that they lack sufficient time to step back and organize.

Humbly, some recognized that "to date, efforts to organize various types of precarious workers and even the unemployed have, with few exceptions, yielded only modest results. One of the reasons is that trade union structures centred upon the workplace are often not suited to new forms of work organization. Another focal point for organization therefore needs to be found." ${ }^{84}$ According to the CEPESIU:

Formal organized workers are not really aware that informal workers do not enjoy the same type of rights. Nor is there recognition that those informal jobs are in fact jobs and that as such, they need to be accompanied by the same

${ }^{82}$ ILO. 2002. Decent work and informal economy. International Labour Conference, $91^{\text {st }}$ Session, 2002 (ILO, Geneva).

83 ILO. 1998. World Labour Report 1997-1998. p. 175

${ }^{84}$ ILO. 1998. World Labour Report 1997-1998. Also in HENK, Thomas, op.cit., p. 15. 
rights. The trade union movement has not been sending a clear message toward the informal economy. For them, the informal economy is something else, on the other side of the fence.

The vulnerable workers' organizations interviewed did not, overall, seem to think that the best way to organize this category of workers would be through the traditional labour movement. Many pointed to the important differences between informal workers and formal workers (who are in a relationship of dependency with an employer) as being one of the major reasons for vulnerable workers to organize on their own. For instance, the CUCUMITAE, the Confederación de Trabajadores Autónomos, mentioned that the law should recognize informal workers as such and acknowledge their different forms of getting organized. While most vulnerable workers' organizations interviewed believed in the autonomy of their organizations, the majority also felt that some networking with formal unions was necessary in order to defend workers' rights at a higher level. The Federación de comerciantes minoristas, FECOMIB, put it this way:

Informal workers need a voice of their own, with alliances with unions, to take advantage of the forces of all.

In a word, "autonomy with alliance" could sum up the opinion shared by vulnerable workers' associations during the interviews conducted.

\section{The viewpoint of trade union organizations}

In a number of countries, as it is the case in Ecuador, trade unions have sometimes been providing services and training to vulnerable workers' associations and have been advocating on behalf of the informal economy actors. ${ }^{85}$ Unions' negotiation skills have often been useful in helping informal workers to voice their concerns to the municipalities and other government institutions. It is in that sense that the Federación provincial de trabajadores del Guayas says that:

Our goal is to help the informal workers to get organize so that they would be able not only to walk, but also to run. We have to help them in organizing so that they can fight for their own rights.

Accordingly, some unions are hesitant to engage more resources into organizing the informal economy workers since the magnitude of the task is impressive, and the plan of action can only be long-term. As observed by Thomas Henk, "it will take much institutional energy to become familiar with the enormous complexities of social relations of production in these spheres, namely enterprises, households, multiple jobs, mobility patterns and social-security systems, yet it is hard to see how this challenge can be avoided". ${ }^{86}$

Most union leaders who took part in the study acknowledged that successes in term of organizing vulnerable workers have been few, although some trade unions have

86 HENK, Thomas. 1995. "Challenges Facing Trade Unions" in Globalization and Third World Trade Unions. The Challenge of Rapid Economic Change. London and New Jersey: Zed books. p. 242. 
undertaken substantial work in sustaining the informal economy workers' organizational aspirations. The Central Ecuatoriana de Organizaciones Clasitas Unitarias de Trabajadores (CEDOCUT), for instance, recognizes the fact that the renewal of the union movement in Ecuador can only be through the organizing of vulnerable workers. This is now one of its top priorities, having helped organize workers in an autonomous federation. Citing a perceived "lack of democratization of the union's structure", an interviewee from the Confederación de Trabajadores del Ecuador (CTE) notes that the number of vulnerable workers who have become close to the union movement remains low. One of their CTE's spokespersons explains that:

\begin{abstract}
Unions have not been able to give adequate responses to the recent changes in the labour relations field. We now have to talk about women's rights, children's rights, migrants' rights and human rights. As a consequence of our limited action in these fields, many movements and organizations have been created to address these issues. They are now making demands and are entitled to a policy response to their demands.
\end{abstract}

Conscious of the many structural implications of such developments, ${ }^{87}$ the CTE has undertaken reflection on the idea of allowing individuals to affiliate to the union federation, "since individual members would give voice to the growing microenterprise sector." Together, those workers could gain easier access to a variety of services, e.g. medical and legal services, access to credit, training, etc. The CTE cautions that vulnerable workers:

should not be used as a political base. This new conception of the labour movement needs to take into account that informal workers represent an important force in Ecuador and that help should be delivered without political strings attached.

Many studies have shown the difficulties that unions face in light of recent economic changes, namely the deregulation, flexibilization and the liberalization of the economy. Union density in many countries, while it may remain high for large firms, has been decreasing over the past ten years. This leads some to question the role of unions in the process of a democratic social dialogue. ${ }^{88}$

While it seems rather clear that vulnerable workers' associations have been pleading for an autonomous organizational base in alliances with trade unions, the trade unions interviewed in this study responded in a more nuanced manner. Most of them, though, acknowledged that the work done so far in the field of organizing vulnerable workers was, for many reasons, not sufficient. For most, organizing the unorganized represents both a challenge and a way to renew the labour movement for the greater objective of defending workers' rights.

87 ILO. 1999. Les syndicats et le secteur informel: Pour une stratégie globale. Colloque international sur l'organisation des travailleurs du secteur non structuré. Genève : ILO/ACTRAV. October 18-22. p. 51.

88 The same question could be asked as regards employers' organizations, but this is beyond the scope of this paper. 
After having looked at the various labour organizations' opinions on whether vulnerable workers should be organized through trade unions, let us now analyse what these same actors have to say on organizing vulnerable workers through their own autonomous associations.

\section{Organising vulnerable workers through autonomous associations}

While up to the 1970s, Latin American workers were expected to follow the same path as those in countries having undergone industrialization, afterward it became clear that this would not be the case. ${ }^{89}$ As was explained by ILO/PREALC, amongst others, "the dynamics and direction of occupational change in Latin America were qualitatively different from those experienced in Europe and the United States." 90 Given these differentiated trends in the pattern of economic development and labour relations, a different approach to looking at the labour situation and organizing might also prove to be useful.

While trade unions face difficulties when trying to organize vulnerable workers, the situation does not seem easier when those workers wish to organize on their own. Some reasons for the lack or organization of the informal economy workers have to do with the characteristics of informal economy organisations themselves. These include these factors:

- Some of the existing organizations are not able to provide enough (quantitatively or qualitatively) services, thus not making them attractive to potential members;

- Few existing organization have been institutionally strong enough to take leadership in the matter;

- There is no specific law regulating the informal economy (or some portion of it);

- Most of the existing organizations have a defensive approach to organizing and only get together in relation to an immediate demand, rather than looking into the advantages of a more permanent organizing structure;

- The fear of the obligation to pay taxes once organized and registered (with no services/rights);

- The complex legal framework related to organising;

- The inappropriateness of an existing organizational model that may not appeal to informal economy workers.

Among the reasons explaining lack of organization of vulnerable workers on their own basis, the focus on immediate goals (for example: street vendors' demands to gain access to the city centre) is cited by trade unions. According to the Federación de trabajadores de la salud de Guayaquil, vulnerable workers lack the "orientation and vision" allowing for their organizations to last. The CEPESIU explains that the:

89 ILO. 2002. Women and Men in the Informal Economy: A Statistical picture. Geneva: ILO/Employment sector. p. 10 
Lack of medium and long term planning (on the part of the vulnerable workers) makes it hard to organize. There is a need to make clear the benefits of permanent representation.

The Confederación de comerciantes Autónomos evokes another reason for the difficulties vulnerable workers have to get organized:

Paradoxically, the municipalities are sometimes responsible for the disorganization of the informal workers. When they give permits directly to the workers, the workers no longer see any need to organize. The municipality has to grant the federations the right of representation. Sometimes, the municipality even lobbies the informal economy workers, telling them that the federations will only rob them of their income. What the municipality wants to do is to destroy the workers' organizations. It's much easier to control disorganized workers.

Thus an additional factor can be interference by the municipality.

The viewpoint of vulnerable workers' associations

Notwithstanding the organizing difficulties, the data collected in the interviews reveal that some vulnerable workers in Ecuador have in fact managed to organize on their own autonomous basis. In Quito, this is the case for the Confederacion de Comerciantes Autónomos, the Coordinadora Nacional de Comerciantes Minoristas, and the Cámara Nacional de Microempresas. In Guayaquil, there are the Federación de comerciantes minoristas de las Bahías, the Cámara de Microempresas, the Sociedad de Carpinteros, the Sociedad de Zapateros and the Asociación de Chóferes Autónomos. Although this study does not pretend to be exhaustive in identifying all the existing associations, it seems inappropriate to say, without qualifying such an assertion, that vulnerable workers are not organized. The Cámara de Microempresas goes further and says that:

By talking about the lack of representation of the informal economy, the legitimacy of our organization is being undermined.

The Confederación de Comerciantes Autónomos also wanted to express the idea that vulnerable workers are somehow organized:

Informal workers are organized. Many organizations exist, like SOCOPO, the association of street vendors, etc. We are fighting for our rights. We have a voluntary coordinating committee, the Coordinadora de Comerciantes Minoristas de Ecuador, and many federations all throughout Ecuador. We have put together a bill addressing street vendors' needs. It's been approved in a first reading in parliament, but we are still waiting for the second reading. It's already been 7 years.

In fact, and at first blush surprisingly so, the existence of too many of such organizations can be seen as one reason invoked by the Federación de Trabajadores de la Salud de Guayaquil to explain the lack of impact of vulnerable workers' organization. The negative effect of this fragmentation is also mentioned by the spokesperson of the Federación 
Ecuatoriana de Indios, describing the important division in social movements in Ecuador. He explains that "some organizations are mestizo, others represent the cholos, others the black people. There is no national forum, no national consensus". The Confederación de Nacionalidades Indigenas del Ecuador refers to the same phenomenon when mentioning that many small organizations, if they would get together, could have a bigger impact when voicing their demands.

The existence of these autonomous organizations does not allow a conclusion about the respect or non-respect of labour rights for vulnerable workers, for the vast majority experiences decent work deficits. But some vulnerable workers, such as craftspeople, have succeeded in organizing themselves and vindicating some rights, namely the right to affiliate to social security systems. In addition, artisans in Ecuador were able to influence the passage of the Act on the promotion of small-scale enterprise (Ley de la promoción de la pequeña industria), and the Act on the defence and promotion of crafts (Ley de defensa y promoción artesanal), which eased access to credit, technology transfer, etc. ${ }^{91}$

In spite of the presence of a certain number of organizations catering to vulnerable workers, some of the associations contacted during this study would rather say that vulnerable workers are in need of getting organized. The Cámara de Microempresas de Guayaquil, representing $10 \%$ of the microenterprises in the country, believes that:

Much has still to be done. The Cámaras should be represented at all levels: local, regional and national, by each economic sector. There should be a more horizontal, democratic and participatory approach.

Most vulnerable workers' associations were of the view that, on the basis of the particularities of vulnerable workers, it might prove fruitful to grant these workers and their organizations an autonomous voice, a right to participate on their own basis in democratic processes like social dialogue. This was the case for the Federación de Trabajadores de la Salud de Guayaquil:

Ideally, informal workers would have their own organizations, for trade unions are (already) preoccupied with their own members. In the new Consejo Nacional del Trabajo, the informal workers must have their own voice. They have to be part of social dialogue.

The interviewees from the Federación de Comerciantes Autónomos de Quito also believe that vulnerable workers would be better represented by a specific association:

91 SANCHEZ, Jeannette. 1996. "El Sector Informal: Una Eterna Alternativa al Desempleo" in Ecuador Debate. No 39. January. 
Informal workers need to be represented as such in order to have their rights defended. They represent the second most important workforce in the country. The person speaking on behalf of the informal workers needs to be informal. Those who are sometimes being heard, the trade unions, do not necessarily have the knowledge or the information needed. They lack the real contact with informality. And then, among the informal workers, few carry out the advocacy role, for a lack of education. Unions, yes, they fight. But they fight for something else. They could be useful in facilitating access to credit, training, education. There is a need for independence, in alliance.

The interviewees from the Cámara de Microempresas de Guayaquil strongly believe that micro-enterprises should be represented by themselves and not by trade unions or employers' associations.

Those from the Federación Ecuatoriana de Indios who were interviewed strongly argue that:

Unions cannot organize the informal workers. They cannot because they are a specific type of association and they organize a specific type of workers: formal workers, who are in a relationship of dependency to an employer. So, in the organizational efforts, they don't meet. They do, however, when it comes to talking about rights.

The CEPESIU interviewses' thoughts go along the same lines:

There is a need for a fourth actor. There is a particular condition of microenterprises that calls for an autonomous and independent representation of their own. Trade unions, employers and governments cannot do it. They have another modus operandi. But the State has to help to put the framework in place, something along collegial lines, where all the sectors of microenterprises could get together.

The vast majority of the interviews conducted with autonomous vulnerable workers' organizations went in the direction of promoting networking with trade unions, but they believed that an autonomous organization of vulnerable workers would be best. The apparently strong stance on an autonomous organizing base is not to be understood as a form of hostility toward trade unions, but rather as recognition of the particularities of the situation facing vulnerable workers. On the contrary, the persons interviewed showed a rather respectful attitude towards one another and a need to act jointly in advocating workers' rights at a global level. In all cases, the necessity for and the will to establish larger links or networks were made clear.

This opinion is clearly expressed by the Federación de Comerciantes Minoristas from Guayaquil. Its spokesperson explains that: 
Informal workers need a voice of their own in alliances with unions, in order to take advantage of the forces of all. Trade unions and informal workers' associations could work together, for they have the same social demands. We all work to eat and subsist, and face problems as consumers. Where there is a difference is in the way to present these demands. The formal workers can formulate them to an employer. The informal workers should have a contract with the municipalities so that could at least have a proper permit to sell.

Among the vulnerable workers' organizations, only one association interviewed believed that workers, no matter where they are in the labour market, should get organized through trade unions. A spokesperson for the Associación de Choferes Autónomos explains that:

The defence of the informal workers' interests should be done through the trade unions, for they have more experience.

The viewpoint of labour organizations

Most vulnerable workers' associations interviewed promoted an autonomous organizational base, in alliance with other social partners - mostly trade unions. The data collected through trade unions seem to go mostly along the same lines. All acknowledged the need to get all workers better organized and all identified the need for establishing broad alliances.

The Confederación de Trabajadores del Ecuador de Quito also had spokespersons who think that it would be more efficient for vulnerable workers to form their own associations first before working in alliances with unions:

Informal workers might not have the culture and education to organize themselves, although there are some informal workers who are very educated. The educated ones and the trade unions could, and should, work together towards facilitating organization.

According to those interviewed from CEDOCUT,

Informal workers have to have their own organizations. Trade unions, though, should help and support the strengthening of these associations. The labour movement in Ecuador has reached its peak. The next steps are the informal workers, the peasants and those in housing cooperatives. But the fact that informal workers don't have an employer makes it hard.

The Federación Provincial de Trabajadores del Guaya, while pleading for unity, nonetheless recognizes the specificity of vulnerable workers. It explains that:

We (informal and formal workers) have to mobilize in a general call for the participation of all those in the informal sector. We have to find the mechanism that will allow this, the way to get to them. This work belongs to us. We have to do it, even though informal workers have their own political and ideological demands. We have to form a massive front. 
The analysis presented by a spokesperson for the CEOSL is interesting for it makes a clear distinction, amongst vulnerable workers, between those who are working under a hidden dependency relationship (contractual) - and who could and should be organized by unions, and the other, "real" "informal" workers, who would best organize on their own, with the support of unions:

The labour movement will never accept that workers' rights are not respected on the pretext that the people involved have been categorized under the term "informal". Workers who depend on employers, in whatever form this employment relationship may take, have rights, whether this employer is an individual, a business or a legal entity. On the other hand, there are the real autonomous workers, and I stress the fact that they don't have an employer. The first group of workers has labour rights. Now, the problem is to have the employer respecting them. The other group do not have labour rights, because they don't have an employer. They have other rights, of a non-labour nature.

From most of the interviews done in relation to vulnerable workers in Ecuador, one strong conclusion can be drawn. A majority of the interviewees, whether associations or trade unions, believe it best for informal workers to first organize on their own basis. This does not exclude broader alliances with trade unions, and those alliances are already being formed. Some examples in the context of Ecuador are mentioned below. Having said that, the opinions of the various organizations interviewed (trade unions and others) are not clear as to how these vulnerable workers' association might participate in social dialogue.

The interviews point out to a strong desire and positive attitude toward supporting the organization of vulnerable workers. Most of the trade unions seemed to believe that the workers who do not fall under the "normal" employment situation should band together on their own, to then create broader alliances with the trade union movement. ${ }^{92}$ Although some dissimilarities have been noted, trade unions clearly point to the existence of a common platform of rights that has to be promoted.

With the growing number of workers who cannot, for many reasons, benefit from the protection afforded by trade unions, there is an increasing need for trade unions to work in collaboration with the associations that have been organizing and promoting non-unionized workers' rights for many years already. It might be worth building on their expertise and know-how. These organizations have some concrete connections with the workers at the grass-roots level.

What also seems clear from the various responses is the existence of a common set of demands linking the labour movement and the vulnerable workers in a broader social justice agenda. To give an example, the Unión General de Trabajadores del Ecuador (UGTE) believes that "formal" and "informal" workers share some common values that call for common organizing action:

92 Successful experiences of organization of vulnerable workers through trade unions are also illustrated in the many cases studies done by the ILO programme on cooperatives and the Workers' Activities Branch (SYNDICOOP). 
The unity of formal and informal workers is the best solution. Formal and informal workers go through the same problems, namely the lack of access to a life with dignity. We all fight for a decent wage. Even the official minimum wage of US $\$ 145$ per month is not enough to cover basic needs, which are estimated at US\$245 per month. There is a need for unity in relation to satisfying basic necessities. There is a unity of interests that makes us complementary. We share common goals that go beyond our immediate economic demands. We all want, for instance, more investment in education.

Beyond the immediate discussion, the data collected from the interviews and a literature review of the political, social and cultural contexts of Ecuador suggested that the issue of voice and representation of vulnerable workers should be looked at from a different angle. The importance of indigenous groups in the country, and the impact they have had in recent years in raising, with substantial success, some social justice issues suggested that the people of Ecuador, including workers, might be organized on the basis of culture or identity. "The social movements of indigenous people are forcing us to reconsider the meaning of struggles beyond the general limitation posed by organizations defined only by class." 93

\section{Organizing vulnerable workers on the basis of cultural identity}

When dealing with the organization of vulnerable workers in Ecuador, another question is suggested. In the political, economic, social and cultural context of Ecuador, is informality as such still a mobilizing concept or do vulnerable workers now tend to regroup around some other issues? Admittedly the significance of "labour" has to do with the definition of work and workers; if labour is to mean something sociologically, it cannot be based on the tradition of industrial sociology where work is defined as male, manual-industrial wage employment. As Vilas comments, "Employment itself has lost its meaning as the gateway to economic well-being and advancement." 94

It has been noted by some that in some Latin American countries, "the labour movement is increasingly dwarfed by urban, indigenous, and even post-guerrilla popular movements, such as the Chiapas rebellion in Mexico." ${ }^{5}$ Though the indigenous movement in Ecuador has traditionally been quite strong, it acquired an increased notoriety in the 1980s. The indigenous movement stands out among similar movements in Latin America for its impressive mobilizing capacities and the fact that it has succeeded in uniting a variety of different ethnic groups throughout the country. ${ }^{96}$ In 1990, what has been called the "Revolución de los Ponchos" marked the official arrival of the Ecuadorian indigenous

93 DELGADO-P., Guillermo. 2002. "The Making of a Transnational Movement" in NACLA: Report on the Americas. Vol XXXV. No 6. May-June, p. 36.

94 VILAS, Carlos. 1999. "The Decline of the Steady Job in Latin America" in NACLA: Report on the Americas. Vol XXXII. No 4. p. 14

95 GARZA, Enrique de la and PRIES, Ludger. 1997. "Work, Workers and Social Change in Latin America” in Current sociology. Vol 45. No 1. January. p. 91.

96 COLLINS, Jennifer. “A Sense of Possibility. Ecuador's Indigenous Movement Takes Center Stage" in NACLA: Report on the Americas. Vol XXXIII. No 5. March-April. p. 42 
movement as a social actor on the political scene. As Melina Selvertson explains, ${ }^{97}$ the adjunction of the indigenous movement was essential to the success of many rallies that had been called by unions. This was notable in the case of the social security strike and the May Day protests of 1993 called by the Frente Unitario del Trabajo. As the labour-based movements have declined in membership, indigenous organizations have demonstrated their ability to mobilize mass protests.

"In some countries, such as Ecuador and Bolivia, resistance to neoliberal reforms has come to centre on indigenous and peasant movements." 98 The peak of the union's strength in Ecuador dates back to the early 1980s. Since then, "the wearing away of its confrontational tactics, and its inability to produce alternative proposals, led to its gradual displacement by indigenous and peasant movements from the centre of the opposition." 99 Therefore, some authors say that the upsurge of the indigenous movement in Ecuador corresponds to the weakening of the labour movement, which it is said were not able to respond to the liberal agenda undertaken by the Government of Ecuador and acted mostly on behalf of their members, leaving aside other segments of the vulnerable/informal worker population and the indigenous communities. ${ }^{100}$

The imposition of this economic model also meant a loss of indigenous people's capacity to have some of their rights respected, which in turn contributed to the consolidation of the indigenous movement. The latter would have therefore substituted itself for the labour movement in proposing a more popular and holistic agenda. ${ }^{101}$

According to some authors, the growth of the "informal" economy, together with its complexity, have confounded economists of various stripes. ${ }^{102}$ In addition, Donna Lee Van Cott explains that both liberals and socialists share a disdain for explicitly ethnic or cultural issues, viewing the situation of indigenous peoples in Latin American society to be an essentially economic issue when it is not, or at least it is not only that. ${ }^{103}$ This might explain the emergence of other types of organizations which filled the gaps left by these two political ideologies.

${ }^{97}$ SELVERTSON, Melina. 1995. "The politics of Culture: Indigenous Peoples and the State in Ecuador" in VAN COTT, Donna Lee. Op.cit.

98 GARZA, Enrique de la and PRIES, Ludger. 1997. "Work, Workers and Social Change in Latin America" in Current sociology. Vol 45, No 1. January. p. 97.

99 GARZA, Enrique de la and PRIES, Lucger. 1997. "Work, Workers and Social Change in Latin America" in Current sociology. Vol 45, No 1. January. p. 98.

${ }^{100}$ BONNASSIES, Violaine. 2004. Le mouvement indigène en Equateur. Montréal : Cahier de recherche du CEIM, p. 5.

${ }^{101}$ MOUTERDE, Pierre. 2002. Quand l'utopie ne désarme pas Les pratiques alternatives de la gauche latino américaine s. Montréal : Ecosociété, p. 92.

${ }^{102}$ CHEN, Marta Alter, Renana JHABVALA and Frances LUND. 2002. Supporting Workers in the Informal Economy: A policy framework. Geneva: ILO. p. 3

${ }^{103}$ Van COTT, Donna Lee (eds). 1995. Indigenous peoples and democracy in Latin America. New York: St Martin's press in association with The Inter-American Dialogue p. 5 
Furthermore, as in Mexico ${ }^{104}$ the indigenous movement has been quite active in catering to other sectors of the population, broadening the movement from initially a primarily cultural identity-based organization to one addressing issues relevant to (almost) all Ecuadorians. The multiplication of transversal alliances between various components of the social movement within Ecuador aims at establishing new communication channels to voice demands that concern the vast majority of the population. These expressions show clearly distinct realities: a new protagonism, new strategies, new dimensions and alternative responses in constructing a new identity and citizenship. ${ }^{105}$

As such, indigenous organizations directly address the legitimacy of liberal democracy, challenging it through a culture of resistance and an alternative vision that is not only based on improving working conditions. "Cultural resistance forges political unity and builds the trenches from which effective political challenge can later occur". ${ }^{106}$

This study included interviews with two indigenous organizations: the well-known CONAIE and the Federación Ecuatoriana de Indios (FEI). They have a stake in decent work related issues due to the fact that many indigenous people suffer from important deficits in the realm of labour conditions - though this is more the case in rural Ecuador. The analysis of their discourse and a review of literature suggest that informality is seen as the consequence of the economic model now being implemented in Ecuador. As such, the informal economy might not be the immediate object of the indigenous population's organizational drive. In contrast to the labour movement, they act more as a social movement although they cater to the same wide segment of the population, the vulnerable workers.

The "cosmovision" of the indigenous movement and its socio-political platform goes beyond to embrace "the universe", aiming for an economy with a human face, an economy based on solidarity and respect for the environment. Indigenous people come to the conclusion that "on top of the little satisfaction generated by industrial and urban life, which is based on consumption, it seems that there is no other remedy than to support it with the strength of the State, with all citizens contributing through their income taxes to put in place a smooth transition leading to another model of life for all". ${ }^{107}$ Some authors have observed that "the cause of the indigenous people has had the support of the population, but this is not the case for the leaders of the FUT (Frente Unico del Trabajo $) ",{ }^{108}$ which is a traditional labour federation

Without diminishing the many ideological differences between the diverse indigenous organizations, indigenous cultures have a rather distinct vision from the current development model which is reflected in their participation in institutional settings. In relation to neighbouring Colombia, Gladys Melo-Pinzón points out that indigenous

104 HEWITT de ALCANTARA, Cynthia. 1984. Anthropological Perspectives on Rural Mexico. London: Routledge and Kegan Paul. Chapter 5.

105 MELO-PINZON, Gladys. 2004. "La identidad y la ciudadanía en América Latina: la resistencia civil y pacífica indígena colombiana bajo el fuego cruzado » in La chronique des Amériques. Observatoire des Amériques. Montréal (Université du Québec à Montréal) No 32. Octobre. p. 3

106 HALE, Charles R. 2004. "Rethinking Indigenous Politics in the Era of the "Indio Permitido" in NACLA: Report on the Americas. September-October. p. 18

107 ASTIGARRAGA, Juan Bautista. 1999. "La tecnología apropiada. Fomento del empleo y conservación de la naturaleza" in SERRANO, Vladimir (eds). 1999. Economia de solidaridad y cosmovision indigena. Quito: Abya Yala, p. 43.

${ }^{108}$ SELVERTSON, Melina. in Van COTT, Donna Lee. Op.cit. p. 132. 
organizations feature new ways of conducting politics. They are suffering from a downgrading of traditional mechanisms of intermediation between society and the State. ${ }^{109}$ The CEPESIU seems to confirm this and gives an explanation of the legitimacy that the indigenous movement in Ecuador may have won in the eyes of the majority of the population.

The resistance to the capitalist system is not lived through the economic activity of informal workers; rather it is through their political and social involvement elsewhere, which is parallel but distinct.

In reviewing the information collected through the interviews in this study, caution is in order in assessing the level of organization of vulnerable workers in Ecuador. Traditional unions have expressed their concerns about the hardships faced by these workers, and although some efforts have been made towards helping them to organize themselves, much remain to be done.

At the same time, there are some a vulnerable workers' associations catering specifically to these workers. Both trade unions and these specialized associations seem to think that vulnerable workers should first get organized on their own basis before networking with one another. The other question raised by the cultural, economic, social and political specificity of the Ecuadorian context is the possible shift of the organizational basis for vulnerable workers from a strictly labour-centred process to one encompassing wider issues, such as a striving for social justice for all.

\section{Representation of vulnerable workers}

Being organized is, as such, often referred to as a source empowerment that has value in itself. Most often, however, people get organised to voice specific concerns they may have. In many cases this is done through participation in some kind of social dialogue.

It has already been seen that informal workers in Ecuador have some degree of organization (whether through trade unions, various associations or other cultural organizations). This does not ignore the need to strengthen existing organisations, as identified in the literature reviewed and during the interviews. Besides, just because these workers have some form of organization does not mean that all their decent work deficits have been addressed. In this section, it will be argued that they might not have a corresponding level of participation in social dialogue processes and therefore might not voice their concerns in a way that sits easily in a democratic system. Another reason could be that their voice and concerns do not get to be the centre of public attention and policies.

The extent of organization of indigenous people is rather important. Indigenous organizations seem to be advocating social justice, thus indirectly addressing the issue of informality. This distinction seems significant, since it will have an impact on how vulnerable workers' concerns will be voiced in Ecuadorian society.

As far as representation or participation of vulnerable workers' organisations in democratic processes or social dialogue is concerned, most of those interviewed seem to agree on the

${ }^{109}$ MELO-PINZON, Gladys. 2004. "La identidad y la ciudadanía en América Latina : la resistencia civil y pacífica indígena colombiana bajo el fuego cruzado » in La chronique des Amériques. Observatoire des Amériques. Montréal (Université du Québec à Montréal) No 32. Octobre. p. 3 
low level of representation of vulnerable workers. A better look at this impression and what is being proposed will be set out in this section.

Within the spectrum of representation, a further distinction has to be made between representation in formal democratic institutions (such as social dialogue and tripartism) and representation in other types of fora.

Given what was mentioned earlier about the (radical) political proposals put forward by indigenous communities and their fundamental nature (calling for a societal change and not "only" for an improvement of working conditions for vulnerable workers), together with the low level of legitimacy granted to formal institutions, the participation in formal representational institutions can be expected to be low in Ecuador. On the other hand, it has to be acknowledged that the level of participation and representation in some other civic fora is quite high. Illustrations of this are the mobilizing around the Hemispheric Social Alliance (HSA), an important international network regrouping social movements in the Americas that are opposed to the on going economic integration process, the World Social Forum, and mobilization against the privatization of important Ecuadorian institutions.

\section{Representation in official institutions: social dialogue and tripartism}

Tripartism, and more broadly, social dialogue constitutes one of the core value of the ILO. It has been the modus operandi of the Organization since its inception, in 1919. Throughout the history of the Organization, it has been reaffirmed as one of the major mechanism to attain or maintain, not only social peace but economic, social and political development and stability, equity and democracy, ${ }^{110}$ through dealing with labour issues, whether in a national or international context. In 1976 a Convention was adopted for the promotion of tripartite consultations, and in 2002 tripartism and social dialogue were the objects of a resolution of the International Labour Conference. In 1999, social dialogue became one of the four strategic objectives of the ILO to underpin the promotion of decent work. ${ }^{111}$

Within the context of the ILO, the term "tripartism" has quite a precise meaning and it is understood as "all dealings between the State - normally represented by the government and employers and workers concerning the formulation or implementation of economic or social policy". ${ }^{112}$

Social dialogue is therefore understood as "all types of negotiation, consultation or simply the exchange of information, usually between the representatives of government, employers and workers, on issues of common interest relating to economic and social policy". Social dialogue, with its many ways of being implemented, involves a process of

\footnotetext{
110 FASHOYIN, Tayo. 2004. Tripartite Cooperation, Social Dialogue and National Development" in International Labour Review. Vol 143, No 4.

111 The three other ones are the promotion of employment and social protection as well as promotion of fundamental labour rights
}

112 ILO. 1996. Tripartite consultation at the national level on economic and social policy. Geneva: ILO. Report VI of the $83^{\text {rd }}$ session. p. 5 
"peaceful resolution of conflicting interests which, although persisting, must be conciliated in order to attenuate the feeling of powerlessness on the part of citizens". ${ }^{113}$

Civil dialogue is yet something else. While social dialogue aims at including, in a common discussion process, all actors relevant to economic and social policy, civil dialogue's agenda is broader, and involves means to invite a large spectrum of civil society organizations with the aim of fostering social inclusion.

In the context of globalization, tripartism, social dialogue and civil dialogue undoubtedly have a major role in trying to ensure that the vast majority of people around the world and in any national setting benefit from the current socio-economic trends. However, changes in the labour market and in the relationships between the state, employers and workers are also introducing deep changes in what can be called the "culture of work" or "the combination of attitudes, behaviours, ideas and symbolic understandings of the population in general, and of workers in particular, about the nature of work". ${ }^{114}$

This is one of the reasons why the ILO has devoted resources to the strengthening of social partners. "It is observed that trade unions are being affected by the new forms of production and organization of work, technological change, legal obstacles and the "new ideological current that are calling collective actions in question'.... "It is therefore necessary to strengthen the three players if social dialogue, tripartism, and pluralist democracy are to thrive". ${ }^{115}$ It is hoped that in doing so, a virtuous circle will emerge that will bring along stronger and more representative players, real and fluid social dialogue, and entrenchment of pluralist democracy.

\section{Social dialogue in Ecuador}

A certain number of issues are also important in implementing an effective social dialogue process. The institutional framework in which the discussion takes place, the willingness to engage in a process that raises the issue of representation and participation of relevant actors, the significance of the agenda and the expected outcomes from participating in the social dialogue process (which includes the social costs of participating), offer some examples. These characteristics have often been associated with what good governance should be. ${ }^{116}$ Without good governance, social dialogue, whether it includes or does not include vulnerable workers, can hardly render the expected results.

Ecuador, like some other countries in Latin America, has suffered from a lack of these characteristics. With an incomplete democracy, a concentration of wealth that has been described as "offensive" and an excessive economic dependency on external institutions and countries, the social dialogue processes in the country can hardly be qualified as successful.

113 ILO. 2000. Trade unions and social dialogue: current situation and outlook. Geneva: Labour Education. P. V

114 VILAS, Carlos. 1999. "The Decline of the Steady Job in Latin America" in NACLA: Report on the Americas. Vol XXXII. No 4. January-February. p. 20.

115 ERMIDA, Oscar. 2000. «"Social dialogue : theory and practice," in Trade unions and social dialogue: Current situation and outlook. Geneva: ILO. Labour education, No 120, p. 53.

${ }^{116}$ FASHOYIN, Tayo. 2004. "Tripartite Cooperation, Social Dialogue and National Development," in International Labour Review, Vol. 143, No 4. 
In 2001, Raúl Borjá conducted for the ILO an in depth investigation in Ecuador in order to document the social dialogue and concertation processes that took place in the country between 1992 and 2001. This investigation explicitly addresses the issue of voice and representation of vulnerable workers, and can illustrate the social dialogue context in which these workers could participate. ${ }^{117} \mathrm{He}$ describes the many phases through which the social partners went, oscillating from fruitful collaboration to periods of open tension. This irregularity in the social dialogue process might be one reason explaining the reluctance of some of the actors interviewed in the course of the current investigation, in participating further in social dialogue.

In the 1980s, the favourable political will of Presidents Jaime Roldós and Osvaldo Hurtado toward social dialogue opened discussion channels between employers and unions around a national agenda for a "Nueva Patria". Unfortunately, the taking over of presidential responsibilities by León Febres resulted in a drastic change in the attitude of the government in relation to social dialogue. Tensions rose on all sides, raising suspicions about the process of social dialogue.

In 1988, under the social democratic President Borja, discussions were initiated in order to reform the Labour Code. Those reforms were understood by social partners, mostly trade unions, as accelerating the flexibilization of the labour market, and discussions around the modification were difficult. Reform of the social security scheme and unified wage rates were the two themes that the following President, Sixto Duran (in office 1992-1996), brought to the negotiating table. A national referendum on what was portrayed as the privatization of the Instituto Ecuatoriano de Seguro Social fell through. The wage discussions did not end on a positive note.

In 1996, President Abdulah Bucaram (who served from August 1996-February 1997) and his minister of Labour, Guadalupe León, were able rapidly to get traditional social partners to agree on the Protocolo para el Proceso de Concertación a fin de lograr el Pacto Social (protocol for the conceration process aimed at reaching a social pact), which contained provisions for future social dialogue processes. The government lasted only a short time, however (until 5 February 1997). The workplan for the planned negotiations was very broad and included:

- The alleviation of unemployment in order to decrease poverty and favour better conditions of living for low-income people;

- Investment for job creation in the rural and urban marginalized sectors;

- Training policy based on employers' needs;

117 BORJA, Raúl. 2001. El Proceso de Diálogo social y Concertación en Ecuador. Quito: OIT/Equipo técnico Multidisciplinario para los países andinos., p. 19 et seq. 
- National social security system;

- Reform of the Labour Code and;

- Wage policy.

According to Raúl Borja, President Bucaram's succession was quite tense. Various social movements, under the umbrella of the Frente Popular, and other trade unions, under the umbrella of the Frente Unico del trabajo (FUT), did not agree on the nomination of Alarcón as interim President. In spite of the political turmoil, the Minister of Labour, Edgar Rivadeneira, was able to get enough consensus among traditional social partners to get the Protocolo ratified. The fragile political equilibrium that existed then in Ecuador, the falling price of oil that exacerbated the economic difficulties, the creation of the Constituent Assembly whose responsibility was to draw up the new Constitution, and the rotation of the then Minister of Labour to another governmental function eroded the favourable context that had previously led to a certain level of agreement between traditional social partners.

During the Alarcón presidency (February 1997-August 1998), it is worth noting that many social sectors that were not usually included as traditional social partners were allowed to take part in the negotiations on the various themes put on the agenda. These included rural organizations and many of CONAIE's federations, the Confederacion Nacional de Organizaciones Campesinas, Indigenas y Negras (FENOCIN), among others. This was an illustration of the possible opening up of the tripartite model, "tripartism plus", as is explained in the recent work by Tayo Fashoyin. ${ }^{118}$

After the overthrow of President Mahuad (who served from August 1998-January 2000), social dialogue in Ecuador was put into jeopardy. Leaving aside the political difficulties that were mentioned earlier, Ecuador underwent a severe economic crisis. President Noboa (January 2000-January 2003) and President Gutiérrez (January 2003 until the drafting of this paper (he was later replaced by Alfredo Palacío) have had to deal with social unrest that made the implementation of serious social dialogue among the social partners quite a complicated task. In recent years, voicing demands through social dialogue in Ecuador has not proved to be effective. The social actors' strategy might have thus shifted and they might have had to find other ways to "be heard". The massive rallies Ecuador has seen in recent years, namely the one related to the Free Trade Agreement of the Americas (FTAA) and the World Social Forum might be examples of this shift. This has entailed a broadening of the agenda around which people voice their concerns, leaving behind, as a consequence, strictly related labour issues to tackle what is believed to be the degradation of the quality of life of the majority of the people.

The persons interviewed in this study shared their views in relation to social dialogue in Ecuador. Though critical about the way it is being implemented in Ecuador, social dialogue seems to be an institution held in much esteem by the actors interviewed. Trade unions are positive on the matter. Many of the vulnerable workers' associations interviewed also share this view. As stated by a representative of the Federación de Comerciantes Autónomos:

118 FASHOYIN, Tayo. 2004 a). "Tripartism and Other Actors in Social Dialogue". International Journal of Comparatives Labour Law and Industrial. (forthcoming), and FASHOYIN, Tayo. 2004 b). "Tripartite Cooperation, Social Dialogue and National Development" in International Labour Review, Vol 144. No 4. 
The only possible way to have our concerns voiced is through social dialogue.

The CONAIE also believes in the importance of the social dialogue process, and in the role of the ILO in ensuring that it is implemented seriously.

The ILO is a very important institution. It must continue to defend the people's rights, indigenous and poor people, through social dialogue.

However, the issues at stake nowadays do not seem to be to find satisfactory resolution through a narrow social dialogue process. The majority of the population is indigenous, without stable employment; they voice concerns that go well beyond traditional labour issues, such as education, health, land, oil mining, communications, infrastructure, environmental concerns, making a social dialogue process strictly focussed on labour issues somehow less relevant. Furthermore, in the case of Ecuador, much of those broader claims are being channelled through the CONAIE rather than through the trade union confederations.

Nonetheless, social dialogue seems to be a valued institution, although the issue of good governance as a pre-condition to any serious discussions came through quite strongly, as can be seen below.

\section{Social dialogue and good governance}

The data collected indicate a strong attachment to the idea of social dialogue. Many vulnerable workers' associations are more vocal in mentioning the existence of deficits relating to prerequisites for social dialogue, however. The Confederación de Trabajadores Autónomos is of the view that:

Social dialogue has not given any concrete results for informal workers. Employers and governments do not respect the decisions made in those fora. And even more, they infringe on labour rights. As such, we don't want to take part in social dialogue.

Some trade unions also mentioned some reservations about the way social dialogue has been functioning in Ecuador. A spokesperson for the CEDOCUT, for instance, expressed this opinion:

Concertation is a good thing. But it has to be open and honest concertation. The creation of the National Labour Council, for instance, did not seem to be a real success. There is a need to institutionalize the process of social dialogue, so that the participants have a sense of their responsibility. 
In relation to social dialogue and vulnerable workers, this is what the Confederación de Trabajadores del Ecuador had to say:

\begin{abstract}
Social dialogue is an important mechanism for workers. Recently, in tripartite meetings, unions have not been participating much. There is no representation of informal organizations. The number of workers that got close to the union movement is low. We have to start with the informal economy associations that exist, and social dialogue has to be genuine. Often, it has been empty. Then, the only thing that comes out is the loss of confidence. The ILO has taken its role seriously. The government less so. It often favours political calculations.
\end{abstract}

Globalization also diminishes the power of the State and its capacity to act as a guarantor of the social dialogue process, as an institution able to implement the labour policies elaborated in the process. Often, real leeway for negotiation is rather narrow, with most of the issues having being discussed beforehand. As such, the social dialogue process discusses the way measures will be implemented, and not so much what those measures should be. The Federación Provincial de Trabajadores del Guayas seems to share this opinion:

\begin{abstract}
When there is predisposition and good will, everything can be done. The government has the possibility to do it all. Call, negotiate, listen. Unfortunately, we do not want to listen to it, for it has sold out the nation to interests from the North (in relation to free trade agreements). The State is led by economic priorities that are not those of the people. We have never stopped the dialogue process. But this dialogue has to be serious and honest. It cannot be the type of dialogue where there is an apparent disposition to listen, and then people do the opposite.
\end{abstract}

\title{
Including vulnerable workers in social dialogue
}

As discussed earlier in relation to trade unions and autonomous organizations, vulnerable workers should be organized on the basis of their own interests. It is just as evident for the majority of the labour unions interviewed that the issue of vulnerable workers should be addressed in tripartite or a "tripartite plus" forum. Whether it would be best to do so through distinct representation of vulnerable workers' association or via the affiliation to some labour unions is less clear, however.

\section{As part of the already established social dialogue structures (through trade unions)}

Few trade unions interviewed have stated clearly that vulnerable workers would be best represented, in the social dialogue process, by already existing unions. This was also the case for one vulnerable workers' organization. The majority of unions and associations interviewed believe that vulnerable workers should have an independent participation right in a renewed social dialogue institution.

As far as the Confederación de Trabajadores del Ecuador is concerned, a doubt subsists as to the possible participation of a fourth pillar in the social dialogue process:

There is a need to think about it, and to find the mechanism to do so (increasing vulnerable workers' voice). 
The Central Ecuatoriana de Organizaciones Sindicales Libres seems to have a clearer opinion on the matter, as expressed by its spokesperson. While believing that vulnerable workers need to be head, this should be done through the present tripartite system.

\begin{abstract}
When we talk about social dialogue, we are talking about workers, employers and governments. The question is: who represents whom? There are two ways to give voice to informal workers. The first one, through existing unions that do represent an important portion of informal workers. The other way would imply a modification to the tripartite system. I see a problem here. The worker who would represent the informal workers may only speak for his or her own economic sector, and leave the other ones aside. I don't see this second alternative as a feasible one. I can just imagine the reaction of the other sectors, like the organizations working for the abolition of child labour, or those working for indigenous rights (mentioning ILO Convention No. 169 on indigenous and tribal peoples). They all could argue for their right to be represented. Workers' representation, within the ILO, is done through national labour organizations. Employers' representation is through the various manufacturers' chambers. And the governments represent themselves. These three constituents are representative and have legitimacy.
\end{abstract}

Only one vulnerable workers' association interviewed believed that the voicing of their concerns would be better done through affiliation to existing unions. For the Asociación de choferes autónomos,

The defence of informal workers should go through the trade unions, for they have more experience.

\title{
In another/autonomous renewed social dialogue structure
}

Most of the organizations interviewed, whether trade unions or associations, seemed to believe that social dialogue should make room for vulnerable workers as such. The Federación Provincial de Trabajadores del Guayas stated that:

There is no alternative representation or participation of unions in the social dialogue process, let alone of informal workers. We must insist on the need for a national concertation process, and on the fact that this concertation must include informal workers, as such. They must have their own voice. Unions cannot make unilateral decisions.

The opinion offered by the Unión General de Trabajadores del Ecuador seems even clearer:

There is a need for some political space to talk about the informal workers' specific circumstances. Informal workers do not fit into social dialogue or tripartism. There is a need to find another form of social dialogue. Government, employers and informal workers need to address the issue. Informality is not something that will just disappear. It is permanent. Therefore there is a need to create specific institutions at the regional and provincial levels. We could think about the National Labour Council. Over time, we could all reunite, but informal workers have their own characteristics. 
In Guayaquil the Federación de Trabajadores de la Salud believes in the same autonomous participation of vulnerable workers. Their spokesperson commented:

Ideally, informal workers would have their own organizations, for unions are preoccupied with their own members. In the new National Labour Council, the informal workers must have their own voice. They have to be part of social dialogue.

The Camara nacional de empresas from Quito believes that social dialogue opens up a space that has not given the results hoped for as far as vulnerable workers are concerned. It has not taken into consideration this broad portion of the economy:

There is a need for proper voice for informal workers. There is a need to go beyond the tripartite ILO's social dialogue. There is a need for new forms of representation of the workers and their participation..

As pointed out earlier, the Federación de Comerciantes Autónomos de Quito believes also that vulnerable workers should have the right to represent their members with a voice of their own.

Informal workers need to be represented as such in order to have their rights defended. (...) The person speaking on behalf of the informal workers needs to be informal. Those who are sometimes being heard, the trade unions, do not necessarily have the knowledge or the information to do so. They sometimes lack real contact with informality.

The Federación de Comerciantes minoristas also believes that they would need to take part, as such, in the social dialogue process to express the specificity of their situation, through alliances with unions.

As might have been expected, the indigenous organizations interviewed also think that vulnerable workers should be allowed to speak for themselves. The Federación Ecuatoriana de Indios asserted that:

Informal workers need their own voice in social dialogue.

The participation of those social movements in a context of a fragile democratic and political system does raise a certain number of issues. The risks associated with the participation of civil society organizations in social dialogue processes has recently been studied by Lucio Baccaro and Konstantino Papadakis in another context (South Africa). ${ }^{119}$ On the one hand, there is the possibility of cooptation of structures, as expressed by some of those interviewed in Ecuador, by corrupted political actors. On the other hand, participation in social dialogue validates the system in place, thus exposing the internal contradiction of a social movement that seeks change in the way the system operates. As an expression of this tension, the events that took place in Quito in January 2000 "reveal

${ }^{119}$ BACCARO, Lucio and Konstantino PAPADAKIS. 2004. "The downside of Deliberative public administration". Paper presented at the Conference on empirical approaches to deliberative politics. Florence: European university Institute. 21-24 may. 
the contradictions and paradoxes that can emerge when social movements attempt to chart an alternative course and vision for social change in contexts where formal democratic institutions have failed to effectively address the profound structural problems of inequality and injustice". ${ }^{120}$ More research would be needed to find out more about these two modes of democracy (representative versus participatory democracy), their similarities and differences, and what kind of collaboration could be expected between these two visions. This research could also point the way to reconcile the logic of social dialogue processes with a more direct participatory approach.

\section{Representation in other civic forums}

While the previous section addressed the issue of representation of vulnerable workers in formal democratic institutions, this section touches upon the possible representation of vulnerable workers' concerns through other channels of representation, less formal yet allowing their concerns to be voiced. This idea flows from what was previously noted in relation to the strong presence of indigenous movements in Ecuador. Indigenous movements have developed a critique and an alternative to the current social model in place in Ecuador, no longer organizing themselves around explicit labour issues. Their platform is broader than strictly labour issues.

The hemispheric social alliance and the Free Trade Agreement of the Americas

In the Americas, and in Ecuador in particular, a great deal of analysis, sensitization and organizing has been going on since the early 1990 s in relation to what has been called the Washington Consensus. ${ }^{121}$ This was a consensus characterized as placing economic growth above all other concerns, with little attention given to other issues relating to social policies and income distribution, to name only those two.

This movement against such an agenda became clear by 1994, at the time of the implementation of the North American Free Trade Agreement (NAFTA). Since then, many governments of the Americas have revived a continental integration scheme that has also fed the organizing and mobilizing efforts of many national coalitions of unions and NGOs (women, environment, youth, human rights, academics, parliamentarians, etc.) in almost all countries of the continent, including Ecuador. As stated by a CEDOCUT leader:

The free market does not yield what was promised. The neoliberal model is one cause of informality.

Together, in 1997, all these national networks of unions and NGOs formed the Hemispheric Social Alliance (HSA). ${ }^{122}$ They all opposed the opacity of the trade negotiations, since Governments were providing hardly any information about the agenda and the items incorporated. The HSA and its members also opposed the lack of protection of workers' rights and the environment, as well as the erosion of States' capacity to decide on their development priorities.

120 COLLINS, Jennifer N. 2000 “A Sense of Possibility. Ecuador's Indigenous Movement Takes Center Stage". In NACLA: Report on the Americas. March/April. p. 41.

121 MONTANO, Cecilia Lopez. 2003. "People first: Standing up to the Washington Consensus" in NACLA. Report on the Americas. Vol XXXVII. No 3. Nov.-Dec., pp. 34-39.

122 http://www.asc-hsa.org/castellano/site/home.php 
The central aim of the HSA is to reflect on and influence the economic and social agenda put forward by the Free Trade Agreement of the Americas (FTAA). Broad educational, mobilizing and voting campaigns ${ }^{123}$ on the issue were put together in many countries, Ecuador among them, all aiming at pinpointing the limits of both the process and its inherent economic model. In publishing a document entitled Alternatives for the Americas, ${ }^{124}$ the campaign also put forward certain elements for an alternative development model. In April 2001, during the third summit of the Americas that took place in Québec city, HSA members, after protesting the lack of democracy in the negotiation process, were given access to the texts being negotiated.

This, in turn, allowed the members from all countries in the Americas to further their analysis of the integration process. The call for action was not made on a labour only agenda, but in association with other social movements calling for a fundamental change in the economic rationale of the Washington Consensus and the FTAA. Social movements acknowledged that the solution to decent work deficits, environmental degradation and the like cannot be pursued in strictly national and/or sectoral action. Given the current globalization context, solution to key problems are located more on a macro level.

The important mobilization that took place around the HAS suggests that vulnerable workers are voicing their concerns through a platform that extends beyond a strictly labour focussed agenda.

\section{World and regional social forums}

In parallel, since the early 1990s, a growing number of unions, NGOs and other types of associations around the world, all integrated under the umbrella of the World Social Forum and the many regional social and thematic fora, have been organizing and advocating the need to find alternatives to the current development model. Recently, Ecuador has been the host of the second indigenous people's forum and the first Americas' social forum. ${ }^{125}$ One of the central organizations having undertaken such a mandate is the CONAIE, which caters to many vulnerable workers.

The Americas regional social forum was organized in Quito in July 2004. More than 11,000 participants registered, from more than 45 countries representing over 814 organizations. Over 425 events were organized, which were covered by 580 journalists disseminating the event in more than 200 different media. ${ }^{126}$ It is worth noting though that in the agenda of this important meeting, labour issues as such (employment, child labour, slave labour, new forms of labour exploitation) were not at the forefront of the debates though these questions were most probably integrated under other broader themes.

123 In Brazil, in 2002, for instance, after a broad information campaign, more than 10 millions persons voted against the FTAA project in a informal referendum organized by the Movimento sem terra and some religious groups. More recently, two millions signatures were presented to President Luis Ignacio Lula Da Silva pleading for the government to organize a national plebiscite on the matter.

${ }^{124}$ http://www.web.ca/ comfront/alts4americas/eng/eng.html

125 SEOANE, José and Emilio TADDEI. 2003. "Levantamiento popular y luchas sociales en América Latina: del "octubre boliviano" a las protestas contra el ALCA. Cronología de septiembre hasta diciembre 2003" in Revista del Observatorio social de las Américas. No 12. Sept., p. 80.

${ }^{126}$ BRUNELLE, Dorval. "Le premier Forum social des Amériques. Quito. 26 au 30 juillet 2004” in La chronique des Amériques. No 23. August 2004. 
In parallel, also in Quito, the Second Summit of indigenous people of the Americas was organized showing a important participation of the social movements, though on a broader platform than informality, asking for social justice. ${ }^{127}$

\section{Mobilizing against the liberal agenda}

Another example of the representational capacity of social movements in Ecuador was the massive mobilization against the privatization of electricity in $2002 .{ }^{128}$ The same scenario occurred over the privatization of telecommunications industry. In the 1990s, Ecuador saw major mobilizations over the plans to implement many IMF-recommended structural reforms, testifying to their capacity to voice their concerns (but not necessarily to find solutions to the problems). In 2000, the Investment Promotion and Citizen Participation Law, which aimed at regulating the industries that the government hoped to privatize and at making the labour market more flexible (an IMF target under the 2003 stand-by arrangement) was defeated in Congress in light of much political protest. The bill was still on the agenda of the government in power in January 2005, but given political opposition (from social movements and political fragmentation in the Congress) it unlikely to become law.

Through CONAIE's formation in 1986, indigenous people and indeed Ecuadorian society as a whole are now quite organized and able to act as political actors. Claims that vulnerable workers have a weak or no voice should thus be treated with caution.

The Observatorio Social de las Américas, a renowned academic institution in Buenos Aires, has been collecting information on the "level of conflict" in all Latin American countries for the past four years. Information on Ecuador shows a high level of social and political activity, mostly led by the indigenous movement, showing by the same token an important level of organization and capacity to voice their concerns. ${ }^{129}$

Another institution charting socio-political activity in the country, Ecuador debate, ${ }^{130}$ while reporting a period of relative calm between November and February 2004, also presents similar conclusions as far as indigenous organizations and the level of their political activity are concerned.

Indigenous people were quite instrumental in the orchestration of a number of social protests that occurred during the 1990s in Ecuador, as well as in the Hemispheric Social Alliance and world, regional and thematic social forums.

Until the mid-1990s, CONAIE, which groups the majority of indigenous in the country, who make up a good proportion of vulnerable workers, pursued a central argument of rejection of the State on the ground of its "exclusionary, hegemonic, antidemocratic and repressive" manner. ${ }^{131}$ The political platform of the CONAIE projects an alternative State, based on pluralistic and participatory values where poverty and discrimination would not

127 http://www.cumbreindigenabyayala.org.

128 Economist Intelligence Unit. 2004. Ecuador. Country profile 2004. London: Economist Intelligence Unit, p. 27.

129 http://osal.clacso.org/espanol/html/frevista.html.

130 http://www.dlh.lahora.com.ec/paginas/debate/paginas/debate1034.htm.

131 Consejo de Gobierno de la CONAIE. 1994. Proyecto politico de la CONAIE, Quito. p. 7 in COLLINS, op.cit. 
exist and where cultural identities would be respected. "Disillusioned by developmentalist policies and neoliberalism, indigenous movements have articulated an international network of mutual assistance". ${ }^{132}$

Until 1995, the CONAIE's official position was to urge its members not to participate in elections. Miguel Lluco, a Pachakutik leader, believed then that the "system did not offer any guarantee of responding to the interests of the whole, much less to Indian interests". ${ }^{133}$ They have argued that the official democratic mechanisms put in place by the State are not legitimate. This attitude spills over into the realm of social dialogue.

The hesitancy of vulnerable workers to participate in any form of social dialogue might as well be explained by "a complete loss of faith in virtually all Ecuador's political institutions." 134 Opinion polls show that people believe that the government works in favour of the establishment to the detriment of the poor majority of Ecuadorians. This issue is closely linked to the lack of governance mentioned above and explains their organizing and mobilizing "outside" formal institutions.

The existence of such a culture of resistance might explain the difficulty that vulnerable workers' organizations face to create a vast "unified" movement, in spite of the exclusion and hardship most informal workers are facing. The existence of various political factions among vulnerable workers, some accepting the terms of the present development model and others rejecting it, make it hard to organize them.

According to Selvertson, "cultural demands of the indigenous movement have allowed them to reinvent indigenous identity and create a political force that neither the left nor the State in Ecuador expected." ${ }^{\prime 35}$ It seems that the traditional left-right approach to society is not useful in this context. As such, given the numerical importance of indigenous people in Ecuador and given the fact that they are overrepresented in the category of vulnerable workers, a traditional approach to economic, social or political problems might not be lead to solutions for the many problems faced by the population. "Participants in the indigenous movement in these new social movements are engaging in forms of social protest that do not necessarily fit into the traditional schemes of left-right politics." ${ }^{136}$ This raises questions about traditional means for voicing peoples' concerns.

It is not yet possible to evaluate the impact of this resistance culture and its influence on the decision made by Ecuadorian civil society organizations (whether organized on the basis of cultural identity or operating in the informal economy) to refrain from participating in official representation for a such as the social dialogue processes described above. It is certainly the case, however, that "indigenous peoples have proposed horizontal coalition building and through the 1990s, have forged ethically and culturally inspired

132 DELGADO-P., Guillermo. 2002. "The Making of a Transnational Movement" in NACLA: Report on the Americas. Vol XXXV. No 6. May-June, p. 37.

133 Quoted in COLLINS, op.cit., p. 44.

134 COLLINS, Jennifer N. 2000 "A sense of possibility. Ecuador's Indigenous Movement Takes Center Stage”. In Nacla: Report on the Americas. March/April, p. 41.

${ }^{135}$ SELVERTSON, Mélina in VAN COTT. op.cit., p. 133.

${ }^{136}$ SELVERTSON, Mélina in VAN COTT. op.cit., p. 134. 
social movements." ${ }^{137}$ According to Donna Lee Van Cott, indigenous organizations are at the forefront of the definition and the articulation of a utopian alternative to the actual development model. ${ }^{138}$ This might play a role in the difficulty found in tailoring broad interests to a strictly labour agenda.

In spite of the apparent intransigent attitude of the social actors in Ecuador, Guillermo Delgado explains that indigenous people have nonetheless pressed for social dialogue, namely with international institutions. "The many dialogues between the governments and indigenous people maintain open space for manoeuvring," ${ }^{139}$ in terms of formal democratic processes. This points out an obvious tension between two strategies put forward by the movement. In fact, "the more radical strategy of calling into question the legitimacy of the whole political system cannot easily coexist with the efforts to get the vote for local and provincial elections" 140 or, more broadly, to just participate in openings for dialogue. Van Cott presents the same conclusions and refers to the desire of the indigenous communities in Ecuador to participate in social dialogue. According to the many actors interviewed in the current study, however, any social dialogue process would need to base itself on good governance practices and transparency, expanding the deliberative space to other actors that have gained respectability and representative status. It seems that in the case of Ecuador, the new Consejo Nacional del Trabajo would be an excellent opportunity to do just that.

One of Raúl Borja's conclusions is that in Ecuador, social dialogue processes have been led in parallel to other negotiation processes whose support would be necessary to gain the political endorsement required for adoption of a measures in Congress. While not clearly mentioning informal economy actors per se, Borja refers to these "other actors" who would need to be taken into account in the social dialogue and concertation processes: the media, universities, NGOs and "other social actors related with the productive process." In order for social dialogue to have a concrete impact for improvement of the working and living condition of most of the Ecuadorian population, there would therefore seem to be a need for better concertation of all the social sectors around broad labour issues.

The revival of social dialogue for the benefit of all depends on the capacity of traditional social dialogue partners to integrate the new realities of labour market. Trade unions and employers' organisations face the same challenge along with governments. The biggest issue is how best to take into account the concerns of the growing number of vulnerable workers in the social, political, cultural and economic agenda of the government. The current study suggests that a number of actors see some room for increased participation of vulnerable workers in the social dialogue process, though the best way to it -- whether as a part of the labour movement or as an autonomous voice - does not seem clear.

137 DELGADO-P., Guillermo. 2002. "The Making of a Transnational Movement" in NACLA: Report on the Americas. Vol XXXV. No 6. May-June, p. 37.

${ }^{138}$ Van COTT, Donna Lee (eds). 1995. Indigenous peoples and democracy in Latin America. New york: St Martin's press in association with The Inter-American Dialogue .12

139 DELGADO-P., Guillermo. 2002. "The Making of a Transnational Movement" in NACLA: Report on the Americas. Vol XXXV. No 6. May-June, p. 38.

140 COLLINS, Jennifer N. 2000 “A sense of possibility. Ecuador's Indigenous Movement Takes Center Stage". In NACLA: Report on the Americas. March/April. p.44. 
A recent ILO report, A Fair Globalization, The role of the ILO, explains that "the ILO's constituents may therefore wish to consider developing a policy of outreach to selected civil society organizations where there is a shared concern on issues of priority to the Organization. As has often been stated, this is not about changing an ILO governance structure that works well; rather, it reflects beliefs that it will prove increasingly useful for the tripartite constituency to find ways to talk and listen to democratic civil society organizations in ways that are consisted with the goals of the Organization and of its constituents." 141

But above all, if representation of vulnerable workers is to be increased through social dialogue, the issue of good governance will have to be addressed. It is a major impediment for many groups, trade unions and others, to participate actively in any formal democratic processes. The report of the World Commission on the Social Dimension of Globalization is clear on this issue. If good governance is an essential prerequisite to social dialogue, the opposite is also true, and the actors interviewed in the course of this investigation showed a strong interest in the social dialogue process. "Labour market institutions, including appropriate legal frameworks, freedom of association, and institutions for dialogue and bargaining are also essential in order to protect the fundamental rights of workers, provide social protection and promote sound industrial relations. Social dialogue is an important component of good governance, and an instrument for participation and accountability. Means are also required to ensure that the inequality of income and wealth remains within acceptable limits so that social cohesion can be strengthened." 142

\section{Conclusion}

This paper intended to address the issue of representation and voice of vulnerable urban workers in Ecuador by interviewing a set of trade unions and vulnerable workers' associations. The time and resources available for this work did not extend to canvassing the opinions of employers and government officials on the matter. Their views are equally important and should be sought.

In spite of the many efforts that have been made in the past decades, the number of workers suffering from decent work deficits has continued to grow. In the case of Ecuador, more than $50 \%$ of the workforce falls into the "informal economy." This percentage calls into question the association of "formal" working arrangements with "normal" employment. Changes in the economic production system in the light of globalization call for a new reading of the concept of informality. Some are now talking about "neoinformality". In many countries, the boundaries between regulated and unregulated employment is vanishing as deregulation of economic activities progresses and flexible working patterns are becoming the norm. Interdependency between "formal" and "informal" economies is growing as they both participate in the same global production system. The number of poor workers involved in formal or informal activities is also growing, questioning the capacity of even a formal job to act as a means to a decent life. This in turn raises the question of the relevance of maintaining the dichotomy of formalinformal as a useful analytical category.

${ }^{141}$ ILO. 2004. A Fair Globalization, The role of the ILO. Geneva: ILO, p. 51.

142 World Commission on the Social Dimension of globalization. 2004. A Fair Globalization: Creating opportunities for all. Geneva: ILO, p. 56. 
For all these reasons, the need to raise the voice and representation of the growing number of workers suffering from decent work deficits remains central as a means of attaining a decent life. The right of association is a cornerstone for all other rights.

In this working paper, the issue of increasing the visibility of the informal workers through statistics has been raised. The need to improve the statistical picture of the informal economy was pointed out by the 2002 ILC report on the informal economy. Too often, the size or registration criteria used do not suffice to identify informal economy workers or units that would need to be addressed by public policies in order to overcome various decent work deficits. This is even more the case today when micro or small businesses that use new technologies may have a high productivity rate, and therefore should perhaps not be considered "informal". The concept of low productivity, rather than the traditional category of informal economy, might prove useful in identifying workers and economic units in need of more effective public policies.

As explored above, one should be careful in assuming that vulnerable workers are not organized. While this investigation does not pretend to have been exhaustive, there are both unions that are now becoming more aware of the necessity of organizing informal workers and associations catering specifically to vulnerable workers. Most of the latter seem to believe that it would be best for vulnerable workers to first organize on their own before establishing strong links with traditional workers' associations (trade unions). Both types of organizations acknowledged the particularities of the working conditions of their members, but converge around some common social demands addressed to governmental authorities.

This study also highlighted the strong indigenous component of the Ecuadorian population, their significant level of organization and the successful dissemination of their political and social agenda throughout the population in general. This makes it hard for workers to organize strictly on the basis of labour issues. Taking into account the impact of globalization and the need to examine the causes of the increasing deficits in relation to work in the country, it seems that social movements are now advocating for a more fundamental debate on social justice and not only seeking an improvement of labour conditions. In other words, indigenous organizations and their broad social justice agenda might occupy the mobilizing possibilities of the population, leaving no space for purely labour-focussed mobilization.

The CONAIE, the FEI and other indigenous and non-indigenous social movements that participate in the same broad network are promoting a platform that goes beyond informality, to address, as they say, the causes of informality: the current economic development model. As a movement that is not primarily labour based, their organizational principle cannot be informality as such, but rather social justice. Consequently, their focus for mobilizing cannot be traditional social democratic processes known as tripartism or social dialogue, but rather society as a whole.

As such, a distinction has to be made between participation in formal democratic institutions and civic participation. While the first shows a fairly low level of participation, specifically as regards vulnerable workers, the level of participation in other civic forums presented in this working paper is important.

The political and economic crisis that occurred in the 1990s, and the responses given to them, deepened the institutional crisis faced by traditional institutions in Ecuador. Consequently some anti-political discourses emerged that assimilated representative politics to political parties and corruption, and accused them of being the causes of national crisis. Socially excluded groups, led by indigenous movements, realized that they were not taken into account when decisions were made and that they was therefore a need to find alternative ways to be heard. This all contributed to a thesis alleging that the traditional expression of liberal democracy had to be revised in order to re-legitimize the democratic 
system, and that new forms of political participation, transcending the traditional political parties, would need to be found.

Further research would be needed to test the hypothesis of the existence of a "resistance" approach to the current economic model which would make vulnerable workers, as the majority of the population, hesitant to embark upon any negotiation/participation process with formal institutions. Many surveys suggest that they lack legitimacy in the opinion of many people. It would also be interesting to evaluate to extent to which keeping to the sidelines of official democratic processes has to do with this cultural or political resistance and how much is due to the alleged lack of good governance of these formal democratic institutions.

There is a need to better articulate representation and participation, between official political representative (for example, of political parties) and the representation of civil society organizations. The aim is to reach a democratic model able to produce the expected results demanded by society and to guarantee fundamental liberties and equality for all citizens. ${ }^{143}$ As the data collected through our set of interviews and a review of the literature has pointed out, there is a strong interest and demand from labour and social movements, the indigenous one in particular, to increase their participation in dialogue processes.

Contemporary political debates now incorporate the idea that the institutional political crisis makes it necessary to accelerate the transition from a representative democratic model to a model giving more space to the various forms of participatory or direct democracy. There are however other issues about the democracy of such a model. Juxtaposing representative democracy to participatory democracy might not prove fruitful, for the two together might best fulfil democratic demands of society today. Participation should not be seen as an alterative to representation, but as a way to strengthen it and legitimize it. There is a need for further research to evaluate the impact of the participation of social movements on the mechanism of institutional democracy.

The creation of the new Consejo Nacional del Trabajo in April 2004 might give vulnerable workers and their representatives, whether trade unions, organizations of the self-employed or indigenous organizations, a means to express their demands. "However, given the enormous problems faced by workers - inequalities of power, violation of working rights, and vulnerabilities of different kinds - which are made more complex by global aspects of environmental sustainability, one wonders whether the time has not come to design totally new goals and action programmes that would address these issues and give new meaning and ideals to trade unionism. Somewhat ambitiously, one might call such a strategy the beginning of a new approach towards economic democracy". ${ }^{144}$

\footnotetext{
${ }^{143}$ César Montufar, director of the Centro Andino de Estudios Internacionales and director of the International studies of the Universidad Andina Simón Bolívar. See: MONTUFAR, César. 2004. "Antipolitica, representación y participación ciudadana" in Ecuador Debate. No 62. Agust.

144 HENK, Thomas. 1995. "Challenges Facing Trade Unions" in Globalization and Third World Trade Unions. The Challenge of Rapid Economic Changes .(London and New Jersey: Zed Books), p. 244.
} 


\section{Bibliography}

ABERS, Rebecca. 2000. Inventing local democracy: grassroots politics in Brazil. Boulder, Colorado: Lynne Rienner Publishers.

BACCARO, Lucio and Konstantino PAPADAKIS. 2004. "The downside of Deliberative public administration". Paper presented at the Conference on empirical approaches to deliberative politics. Florence: European University Institute. 21-24 May.

BAROT, Rohit, Harriet BRADLEY and Steve FENTON. 1999. Ethnicity, Gender and Social Change. Hampshire and London: MacMillan Press Ltd., p. 249.

BID. 2002. Ecaluación del Programa del País. Ecuador 1990-2002. Washington: BID/Oficina de Evaluación y Supervisión.

BONNASSIES, Vionaine. 2004. Le mouvement indigène en Équateur. Note de recherche 04-01. Montréal : Cahier de recherche CEIM.

BORJA, Raúl. 2001. El Proceso de Diálogo Social y Concertación en Ecuador 1992-2001. Quito: OIT/Equipo técnico multidisciplinario para los países andinos, p. 104.

BRONSTEIN, Arturo S. 1995. "L'évolution sociale et les relations professionnelles en Amérique latine: Bilan et perspectives » in Revue internationale du Travail. Vol. 134, No.2, pp. 179-203

BRUNELLE, Dorval. "Le premier Forum social des Amériques. Quito. 26 au 30 juillet 2004" in La chronique des Amériques. No 23, Aug. 2004.

BULLETIN. 1973. The informal Sector and Marginal Groups. Institute of Development Studies. University of Sussex. Vol. 5, No 2/3, p.89.

CASALE, Giuseppe. 1996. Union representativeness in a comparative perspective.: Budapest: ILO/CEET, p. 35.

CHEN, Martha Alter, Renana JHABVALA and Frances LUND. 2002. Supporting Workers in the Informal Economy: A policy framework. Geneva: ILO, p. 36.

COLLINS, Jennifer N. 2000 "A Sense of Possibility. Ecuador's Indigenous Movement Takes Center Stage". In NACLA: Report on the Americas. March/April, pp. 40-46.

CONAIE. 1989. Las nacionalidades indigenas en el Ecuador. Nuestro proceso organizativo. Quito: Ediciones Tincui - Abya-Yala, p. 317.

CONNOLLY, Priscilla. 1985. "The Politics of the Informal Sector: A Critique" in REDCLIFT, Nanneke et Enzo MINGIORE. Beyond Employment. Oxford: Basil Blackwell, pp. 55-91.

CORNEJO, Alberto Moreno. 2000. Economía popular y desarrollo humano. Quito: Abya Yala, p. 153.

CROSS. John. 1998. Informal Politics. Street Vendors and the State in Mexico City. Stanford: Stanford California Press, p. 272. 
DATT, Ruddar (eds.). Organizing the unorganized workers. New Delhi: Vikas Publishing House PVT Ltd., p. 359.

DELGADO-P., Guillermo. 2002. "The Making of a Transnational Movement" in NACLA: Report on the Americas. Vol XXXV, No 6, May-June, pp. 36-39.

DOMBOS, Rainer and Ludger PRIES. 2000. Relaciones laborales entre Mercado y Estado. Sendas de transformación en América Latina. Caracas: Nueva Sociedad Editorial, p. 271.

ECLAC. 2004. Panorama Social. Santiago de Chile.

Economist Intelligence Unit. 2004. Ecuador. Country profile 2004. London: Economist Intelligence Unit, p. 64.

FASHOYIN, Tayo. 2004a. "Tripartism and Other Actors in Social Dialogue". International Journal of Comparatives Labour Law and Industrial Relations.

FASHOYIN, Tayo. 2004b. "Tripartite Cooperation, Social Dialogue and National Development" in International Labour Review, Vol. 143, No 4, pp. 341-371.

GALLI, Rossana and David KUCERA. 2003. Informal Employment in Latin America: Movements over business cycles and the effect of workers' rights. Geneva: International Institute for Labour Studies. DP/145/200, p. 53.

GARZA, Enrique de la and PRIES, Ludger. 1997. "Work, Workers and Social Change in Latin America" in Current sociology, Vol 45, No. 1, Jan., pp. 91-107.

GRZETICH, Antonio. 1995. La subordinación en el sector informal" in Revista de la facultad de derecho. República oriental del Uruguay. No 7. Jan.-Feb., pp. 57-100.

GRZETICH, Antonio and Jaime MEZZERA. 1994. "Sobre el concepto del sector informal y sus consecuencias jurídicas". In Revista de Relasur, No 4, pp. 121-129.

HALE, Richard. 2004. "Rethinking Indigenous Politics in the Era of the "Indio Permitido". in NACLA: Report on the Americas. Sept./Oct., pp. 16-21.

HENK, Thomas. 1995. "The Erosion of Trade Unions" in Globalization and Third World Trade Unions. The Challenge of Rapid Economic Change. London and New Jersey: Zed Books, 2-27 pp.

HENK, Thomas. 1995. "Challenges Facing Trade Unions" in Globalization and Third World Trade Unions. The Challenge of Rapid Economic Change. London and New Jersey: Zed books, pp. 235-246.

ILDIS. 2003. Análisis de Conyutura Económica. Quito: ILDIS/Friedrich Ebert Stiftung, p. 80.

ILO. 2004. A Fair Globalization, The role of the ILO. Geneva: ILO, p. 59.

ILO. 2003. Report on the Turin Workshop on the Follow up to the ILC Conclusions on Decent Work and the Informal Economy. 10-12 Feb. Turin: ILO International Training Center.

ILO. 2003. Análisis de las Políticas y Programas Sociales en Ecuador. Lima. OIT/Oficina Regional para las Américas/Programa IPEC, p. 18. 
ILO. 2002. Decent work and the informal economy. Geneva: ILC/90th Session/Report VI, p. 129.

ILO. 2002. Resolution and conclusions on decent work and the informal economy, in Provisional Record, No. 25, Geneva: ILC/90th Session.

ILO. 2002. Main d'Oeuvre non protégée: quel syndicalisme pour l'économie informelle? Geneva : ILO. Labour Education, No 127.

ILO. 2002. ILO Compendium of official statistics on employment in the informal sector. STAT Working Paper by Ralph Hussmanns and Brigitte du Jeu. Geneva: ILO/Bureau of Statistics, p. 67.

ILO. 2002. Women and Men in the Informal Economy: A Statistical picture. Geneva: ILO/Employment Sector, p. 64.

ILO. 2001. Les syndicats et l'économie mondiale: une histoire inachevée. Geneva : ILO. Education ouvrière. No 124/125, p. 83.

ILO. 2001. Empleo y protección social en Ecuador. Propuestas de la OIT. Quito: ILO. Equipo técnico multidisciplinario para los países andinos, p. 243.

ILO. 2000. Trade Unions and Social Dialogue: Current Situation and Outlook. Geneva: ILO. Labour Education, No 120.

ILO. 1999. Les Syndicats dans le secteur non structuré - quelques repères. Neuf études. Geneva : ILO. Education ouvrière, No 116, p. 162.

ILO. 1999. Les syndicats et le secteur informel: Pour une stratégie globale. Colloque international sur l'organisation des travailleurs du secteur non structuré. Genève : ILO/ACTRAV.,18-22 octobre, p. 70.

ILO. 1997. World Labour report 1997-1998. Geneva: ILO.

ILO. 1996. Tripartite consultation at the national level on economic and social policy. Geneva: ILO. Report VI of the 83rd session, p. 5.

ILO. 1991. Le dilemme du secteur non structuré. 78e CIT. Geneva : ILO, p. 73.

INSTITUTO Latinoamericano de Investigaciones Sociales. 2003. Análisis de Conyuntura Económica del 2003. Quito: Friedrich Ebert Stiftung, p. 80.

LATOUCHE, Serge. 1989. "Les paradoxes de la "normalisation" de l'économie informelle». In Revue Tiers Monde, Tome XXX, No 117, janvier-mars, pp. 227-233.

. 2004. Survivre au développement. Paris : Editions Mille et une nuits, p. 126.

LEVAGGI, Virgilio. 1994. "Las organizaciones empresariales," in Revista de Relasur, No 4, pp. 105-119.

LOOMIS, Terrence M. 2000. "Indigenous populations and sustainable development: Building on indigenous approaches to holistic, self-determined development," in World Development, Vol. 28, No 5, pp. 893-910.

MALDONADO, Carlos. 2004. Pobreza, dolarización y crisis en el Ecuador. Quito: Abya Yala, p. 88. 
MALONEY, William F. 2004. "Informality Revisited" in World Development, Vol 32, No 7, pp. 1159-1178.

MEAD Donald and Christian MORRISSON. 1996. "The Informal Sector Elephant" in World Development, Vol. 24, No 10, pp. 1611-1619.

MELO-PINZON, Gladys. 2004. "La identidad y la ciudadanía en América Latina: la resistencia civil y pacífica indígena colombiana bajo el fuego cruzado" in La chronique des Amériques. Observatoire des Amériques. Montreal (Université du Québec à Montréal), No. 32, Octobre, pp. 1-10.

MONTANO, Cecilia Lopez. 2003. "People first: Standing up to the Washington Consensus," in NACLA. Report on the Americas, Vol XXXVII, No 3, Nov.Dec., pp. 34-39.

MALDONADO, Carlos. 2001. Participación de las organizaciones de comerciantes informales en el proceso politico y las reformas institucionales a nivel local. Pautas metodologicas. Proyecto de investigacion (IFP/SEED/Declaration-ETM Lima). Lima: Oficina regional del trabajo.

MALDONADO, Carlos. 1995. The Informal Sector: Legalization or laissez-faire?" in International Labour Review. Vol 134, No 6, pp. 705-728.

MALDONADO, Carlos. 2004. Pobreza, dolarización y crisis en el Ecuador. Quito: Abya Yala, p. 88.

MONTUFAR, César. 2004. “Antipolítica, representación y participación ciudadana” in Ecuador Debate, No 62, Aug.

MORENO CORNEJO, Alberto. 2000. Economía popular y desarrollo humano. Quito: Abya Yala, p. 153.

MORRISSON, Christian. 1995. Quel cadre institutionnel pour le secteur informel ?. Paris : Centre de développement de l'OCDE. Cahier de politique économique, No 10, p. 34 .

MOUTERDE, Pierre. 2002. Quand l'utopie ne désarme pas. Les pratiques alternatives de la gauche latino américaine. Montréal : Ecosociété, p. 193.

NORTH, Lisa. 1999. "Austerity and Disorder in the Andes," in NACLA: Report on the Americas. July/Aug., Vol XXXIII, No 1, pp. 6-9.

PEREZ, Juan Pablo. 1995. "Globalización y neoinformalidad en América Latina" in Nueva sociedad, No 135, Jan.-Feb., pp. 36-40.

PLACENCIA, Mercedes Ma. 1986. "El sector informal urbano. Notas acerca de su génesis y funcionamiento" in Ecuador debate, No 11, June, pp. 307-317.

PORTES, Alejandro, Manuel CASTELLS and Lauren A BENTON (eds). 2000. The Informal Economy. Studies in Advanced and Less Developed Countries. Baltimore and London: The John Hopkins University Press, p. 327.

PORTES, Alejandro and Richard SCHAUFFLER. 1993. "Competing Perspectives on Latin American Informal Sector," in Population and Development Review, Vol. 19, No 1, pp. 33-60. 
PRIES, Ludger. 1998. "Trabajo y trabajadores por cuenta propia. Marginalización de la teoria sociologica de Mercado de trabajo y movimientos sociales? In CASTRO, Nadya A. E and DEDECCA, Claudio S. A occupaçao na américa latina: tempos mais duros. Serie II. Rio de Janeiro: Congresso latino americano de sociología do trabalho, pp. 83-106.

RAKOSAKI, Kathy A. (ed.). 1994. Contrapunto. The informal Sector Debate in Latin America. Albany: State University of New York Press.

RAHNEMA, Majid. 2003. Quand la misère chasse la pauvreté. Paris. Fayard/Actes Sud, p. 321.

ROGGIERO, Roberto et al. 1996. "The operation of Small Enterprises and the Institutional Framework in Ecuador," in TOKMAN, Victor and Emilio KLEIN. Regulation and the Informal Economy: Microenterprises in Chile, Ecuador and Jamaica. Boulder, Colorado: Lynne Rienner Publishers.

SALMAN, Ton and Annelies ZOOMERS (eds). 2003. Imaging the Andes. Shifting Margins of a Marginal World. Amsterdam: CEDLA. Latin AMerica Studies, No 91, p. 316.

SANCHEZ, Jeannette. 1996. "El sector informal, una eterna alternativa al desempleo" in Ecuador debate, No. 39, Jan.

SANYAL, Biswapriya. 1991. "Organiser les travailleurs indépendants: la politique du secteur non structure urbain " in Revue internationale du travail,. Vol. 130, No 1, pp. 43-62. pp

. 1988. "The Urban Informal Sector Revisited". In Third World Planning Review. Vol 10, No. 1, pp. 65-84.

SCHLYTER, Charlotta. 2002. "International Labour Standards and the Informal Sector: Developments and Dilemma," in Decent Work and the Informal Economy: Abstracts of Working papers. ILO: Employment sector, pp. 9-10.

SELVERTSON, Melina. "The Politics of Identity Reconstruction :Indians and Democracy in Ecuador," in CHALMERS, Douglas A. The New Politics of Inequality in Latin America. Oxford ; New York : Oxford University Press, 1997, p. 644.

SEPULVEDA, Malbran, Juan MANUEL and Maria Luz VEGA RUIZ. 2000. El Diálogo social en los Países andinos: Nuevo camino para los sindicatos?". Geneva: ILO, p. 104.

SERRANO, Vladimir (ed.). 1999. Economía de solidaridad y cosmovisión indígena. Quito: Abya Yala, p. 321.

SOBOTKA, Elzbieta and Marek PLISZKIEWICZ (eds). 1996. La représentativité des partenaires sociaux dans les relations collectives de travail. Varsovie : ministère du Travail et de la Politique sociale.

STAVENHAGEN, Rodolfo. 1997. "Indigenous organizations: rising actors in Latin America," in Revista del CEPAL, No 62, pp. 63-75.

STEARN, Katherine and Maria OTERO (eds). The critical connection. Governments, private institutions, and the informal sector in Latin America. Washington: Action international. Monograph series No 5, p. 157. 
TESSELAAR Annet, Marjon OOSTVEEN and Bram POSTHUMUS. 1997. Organizing change. Strategies for Trade Unions to Organize Women Workers in Economic Sectors with Precarious Labour Conditions. Amsterdam: Stichting FNV Pers., p. 44.

THOMAS, Henk. 1999. "Trade Unions and Development". The Hague: Institute of Social Studies. Discussion Paper No. 100/1999, p. 19.

THOMAS, Jim. 2002. "Decent Work in the Informal Sector in Latin America" in Decent Work and the Informal Economy: Abstracts of working papers (ILO, Geneva).

TOKMAN, Victor and Emilio KLEIN (eds). 1996. Regulation and the Informal Economy. Micro enterprises in Chile, Ecuador and Jamaica. London: Lynne Rienner Publishers, p. 209.

TOKMAN, Victor (ed.). 2001. De la informalidad a la modernidad. Chile: Andros Impresores., p. 258.

TOKMAN, Victor (ed.) 1992. Beyond Regulation. The Informal Economy in Latin America. Boulder and London: Lynne Rienner Publishers, p. 295.

TOKMAN, Victor. 1989. "Policies for a heterogeneous informal sector in Latin America," in World Development, Vol. 17, No 7, pp. 1067-1076.

TOURAINE, Alain. 1987. Actores sociaels y sistemas políticos en America Latina. Chile. OIT. PREALC, p. 256.

TREBILCOCK, Anne. 2005. Decent Work and the Informal Economy. UNU/WIDER Working Paper. Helsinski.

TREBILCOCK, Anne. 1994. "Tripartite consultation and cooperation in national-level economic and social policy-making: an overview" in TREBILCOCK, Anne et al., Toward social dialogue: Tripartite cooperation in national economic and social policy making. Geneva: ILO, p. 45

TREJOS, Juan Diego. 2001. La microempresas de los 90 en Ecuador. Quito: CEPESIU., p. 91.

TRUJILLO, Jorge Léon and Juan Pablo Pérez Sáinz. 1987. "Les syndicats dans la vie équatorienne" in Mondes en développement, Tome 15, No 60, pp. 249-259.

UNDP. 2003. Millennium Development Goals: A compact among nations to end human poverty. New York: UNDP, p. 367.

VALAREZO, Sergio Velez. 1989. El sector informal manufactuteto en el Ecuador. Quito: CIPAD - Publicaciones Tercer Mundo., p. 172.

VAN COTT, Donna Lee (ed.). 1995. Indigenous peoples and democracy in Latin America. New York: St Martin's press in association with The Inter-American Dialogue, p. 271.

VILAS, Carlos. 1999. "The Decline of the Steady Job in Latin America" in NACLA: Report on the Americas, Vol. XXXII, No 4, Jan.-Feb., pp. 15-20.

VOS, Rob. 1999. Ecuador 1999. Crisis económica y protección social. Quito: Abya Yala, p. 210. 
World Commission on the Social Dimension of Globalization. 2004. A Fair Globalization: Creating opportunities for all. Geneva: ILO, p. 188.

ZUIN, Valentina. Business Strategies of Informal Micro-Entrepreneurs in Lima, Peru., Geneva: International Institute for Labour Studies. Decent Work research programme. DP 150/2004., p. 27. 


\section{Annex}


Table A

Type, name of the organizations interviewed

\begin{tabular}{|c|c|}
\hline Type & Name of the organisation \\
\hline \multirow{10}{*}{ 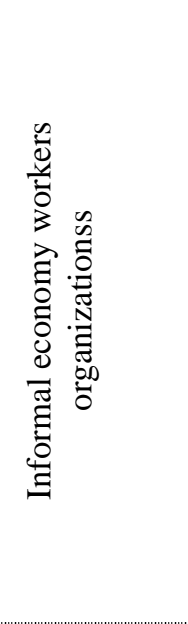 } & Confederación de Trabajadores Autónomos (CUCUMITAE) \\
\hline & Cámara nacional de microempresas \\
\hline & Camada de microempresas \\
\hline & Federación de comerciantes autónomos \\
\hline & Asociación de chóferes autónomos \\
\hline & Fundación Yerbabuena \\
\hline & Sociedad de Zapateros del Guayas \\
\hline & Sociedad de carpinteros del Guayas \\
\hline & Federación ecuatoriana de Indios (FEI) \\
\hline & Confederación nacional de Indígenas de Ecuador (CONAIE) \\
\hline \multirow{7}{*}{ 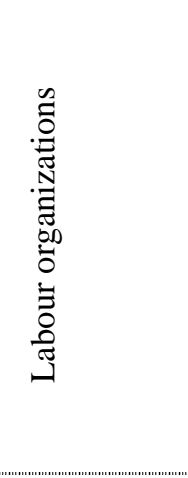 } & $\begin{array}{l}\text { Central ecuatoriana de organizaciones clasitas unitarias de trabajadores } \\
\text { (CEDOCUT) }\end{array}$ \\
\hline & Confederación de trabajadores del Ecuador (CTE) \\
\hline & Unión general de trabajadores del Ecuador (UGTE) \\
\hline & Central ecuatoriana de organizaciones sindicales libres (CEOSL) \\
\hline & Federación provincial de trabajadores del Guayas (FPTG/CTE) \\
\hline & Federación de trabajadores de la salud (FETSAE) \\
\hline & Confederación de organizaciones clasitas (CEDOC/CLAT) \\
\hline \multirow{3}{*}{ 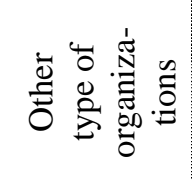 } & Corporación de estudios para el sector informal (CEPESIU) \\
\hline & Centro ecuatoriano de promoción y acción de la mujer (CEPAM) \\
\hline & Sistema integrado de indicadores sociales del Ecuador (SIISE) \\
\hline
\end{tabular}


Table B i)

Employment by ethnic group - 2001

\begin{tabular}{|c|c|c|c|c|c|c|c|c|c|c|c|}
\hline & Total & indigenous & $\%$ & White & $\%$ & mestizo & $\%$ & Blacks & $\%$ & Mulato & $\%$ \\
\hline Economically active & 3'997'563 & $125 ' 267$ & 3.13 & $745^{\prime} 114$ & 18.64 & $2^{\prime} 899 ' 165$ & 72.52 & $118^{\prime} 487$ & 2.96 & $109 ' 530$ & 2.74 \\
\hline Unemployed & $428^{\prime} 137$ & $11 ' 154$ & 2.61 & $65 ' 283$ & 15.25 & $323 ' 943$ & 75.66 & $14 ' 785$ & 3.45 & $12 ' 972$ & 3.03 \\
\hline Agriculture (including mines) & $287 ' 277$ & 8'517 & 2.96 & $48 ' 236$ & 16.79 & $210^{\prime} 114$ & 73.14 & $10^{\prime} 371$ & 3.61 & $10^{\prime} 039$ & 3.49 \\
\hline Non agriculture & $3^{\prime 2} 284^{\prime} 715$ & $105 ' 596$ & 3.21 & $631 ' 595$ & 19.23 & 2'367'674 & 72.08 & $93 ' 331$ & 2.84 & $86^{\prime} 519$ & 2.63 \\
\hline With social security & 1'050'989 & $25 ' 753$ & 2.45 & 250'949 & 23.88 & 736'499 & 70.08 & 20695 & 1.97 & $17 ' 093$ & 1.63 \\
\hline With social security & $801 ' 169$ & $17^{\prime} 833$ & 2.23 & $197 ' 547$ & 24.66 & $555 ' 585$ & 69.35 & $17 ' 589$ & 2.20 & $12^{\prime} 615$ & 1.57 \\
\hline Without social security & $559 ' 149$ & $21^{\prime} 075$ & 3.77 & $101^{\prime} 479$ & 18.15 & 3966884 & 70.94 & $28 ' 348$ & 5.07 & $11^{\prime} 563$ & 2.07 \\
\hline Public sector & $\underline{349 ' 969}$ & $\underline{8^{\prime} 112}$ & 2.32 & $\underline{73} 727$ & 21.07 & $\underline{249 ' 899}$ & $\underline{71.41}$ & 11 '929 & $\underline{3.41}$ & $\underline{6} 302$ & 1.80 \\
\hline With social security & $\overline{295 ' 054}$ & $\overline{7 ' 306}$ & $\overline{2.48}$ & $\overline{61 ' 871}$ & $\overline{20.97}$ & $\overline{212 ' 343}$ & $\overline{71.97}$ & $\overline{8^{\prime} 674}$ & $\overline{2.94}$ & $\overline{4^{\prime} 860}$ & $\overline{1.65}$ \\
\hline Without social security & $54 ' 914$ & 806 & 1.47 & $11 ' 856$ & 21.59 & $37 ' 556$ & 68.39 & 3'254 & 5.93 & $1^{\prime} 442$ & 2.63 \\
\hline Private sector & 1'010'483 & $\underline{30} 795$ & $\underline{3.05}$ & $\underline{225 ' 299}$ & 22.30 & 702' & 69.52 & $\underline{34}, 008$ & $\underline{3.37}$ & $17 ' 876$ & 1.77 \\
\hline ocial security & $506 ' 115$ & $10 ' 527$ & 2.08 & $135^{\prime} 676$ & 26.81 & 343'242 & 67.82 & 8'915 & 1.76 & 7'755 & 1.53 \\
\hline Micro business & $\underline{639 ' 792}$ & $22 ' 580$ & $\underline{3.53}$ & $112 ' 062$ & 17.52 & $\underline{475 ' 135}$ & $\underline{74.26}$ & $13^{\prime} 028$ & $\underline{2.04}$ & $\underline{16 ' 987}$ & 2.66 \\
\hline With social security & $104 ' 417$ & $3^{\prime} 274$ & 3.14 & $24 ' 490$ & 23.45 & $74^{\prime} 081$ & 70.95 & 825 & 0.79 & $1 ' 747$ & 1.67 \\
\hline Without social security & $535^{\prime} 227$ & 19'306 & 3.61 & $87^{\prime} 572$ & 16.36 & $400 ' 906$ & 74.90 & $12 ' 203$ & 2.28 & $15^{\prime} 240$ & 2.85 \\
\hline Own account & 889'976 & $\underline{25} 409$ & 2.86 & $153^{\prime} 446$ & 17.24 & $6599^{\prime} 154$ & $\underline{74.06}$ & $\underline{20} 100$ & 2.26 & $\underline{31 ' 867}$ & $\underline{3.58}$ \\
\hline With social security & 91'286 & $2^{\prime} 416$ & 2.65 & $18 ' 753$ & 20.54 & 68'362 & 74.89 & 1'186 & 1.30 & 569 & 0.62 \\
\hline ocial security & 795'929 & $22 ' 993$ & 2.89 & $134 ' 693$ & 16.92 & $588^{\prime} 030$ & 73.88 & $18 ' 914$ & 2.38 & $31 ' 299$ & 3.93 \\
\hline Workers without remuneration & $161^{\prime} 176$ & 4466 & 2.77 & $\underline{30} 802$ & 19.11 & $119 ' 362$ & 74.06 & $1 ' 909$ & 1.18 & $4{ }^{\prime} 637$ & 2.88 \\
\hline With social security & $11 ' 278$ & 365 & 3.24 & 2'309 & 20.47 & 8'139 & 72.17 & - & 0.00 & 465 & 4.12 \\
\hline Without social security & $147 ' 811$ & 4'101 & 2.77 & $28 ' 492$ & 19.28 & $109 ' 137$ & 73.84 & 1'909 & 1.29 & 4'172 & 2.82 \\
\hline
\end{tabular}




\begin{tabular}{|l|}
\hline Domestic services \\
With social security \\
Without social security
\end{tabular}

$171^{\prime} 077$
$29^{\prime} 349$
$141 ' 730$

$7.76 \quad 24 ' 354$

\begin{tabular}{l|l}
7.76 & $24 ' 354$ \\
6.35 & $2 ' 990$
\end{tabular}

$14.24 \quad 115^{\prime} 779$

$10.1922 ' 768$

67.68

9'879

$15.07 \quad 93^{\prime} 011$

77.58

$9 ' 879$
563

\begin{tabular}{|l|l|l}
$11 ' 419$ & 8.06 & $21 ' 364$
\end{tabular}

19.13 45'840

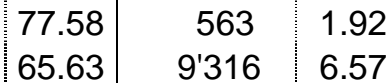

\begin{tabular}{l|l}
$9 ' 316$ & 6.57 \\
\hline $2 ' 478$ & 3.98
\end{tabular}

7'782

Without social security

$62 ' 240$

\begin{tabular}{l|l|l}
949 & 1.52 & $11^{\prime} 905$
\end{tabular}

73.65

Source: INEC, various years as processed by Sistema de información y análisis laboral/OIT 
Table B ii)

Employment by ethnic group - 2002

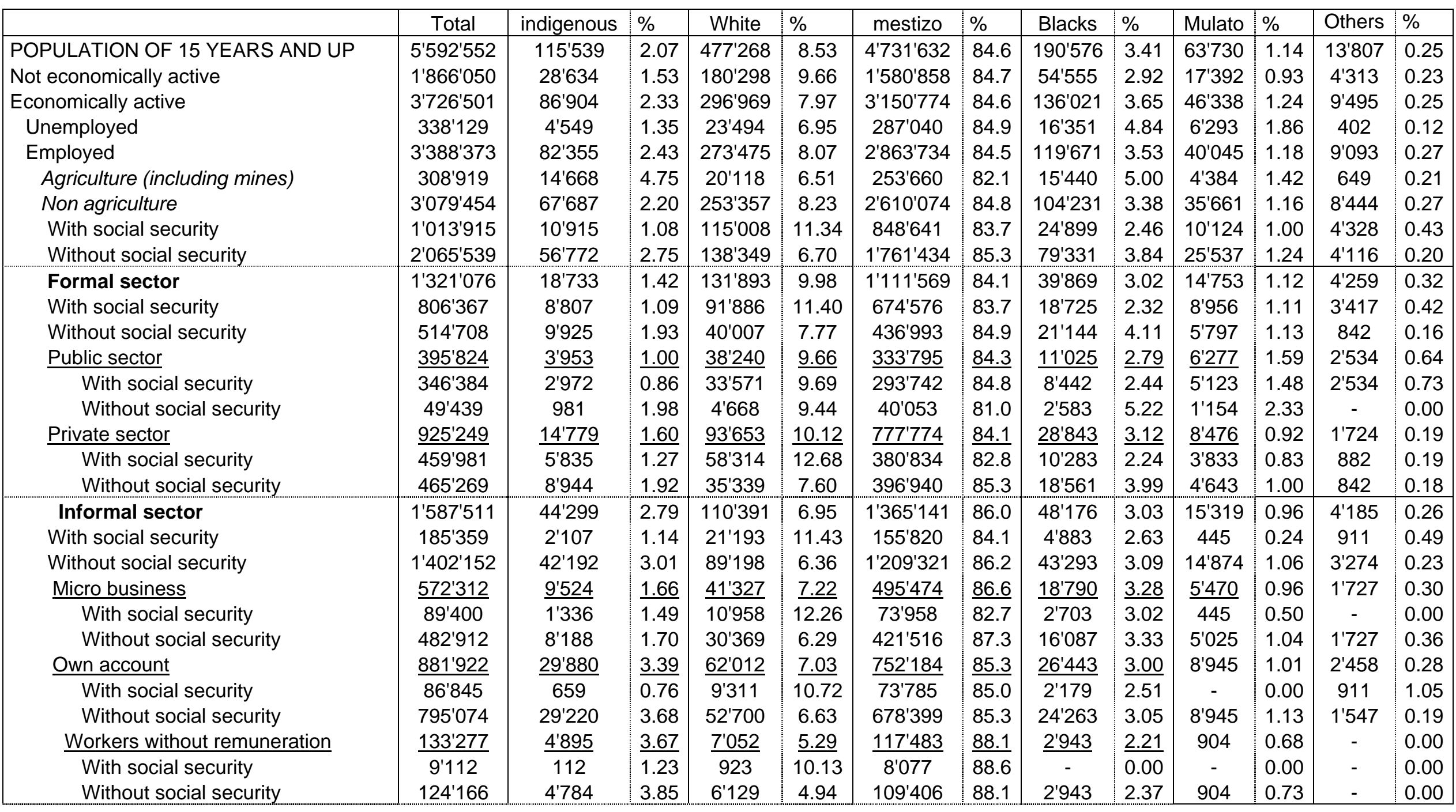




\begin{tabular}{|c|r|r|r|r|r|r|r|r|r|r|r|r|r|}
\hline Domestic services & $149^{\prime} 732$ & $4^{\prime} 655$ & 3.11 & $10^{\prime} 242$ & 6.84 & $115^{\prime} 859$ & 77.4 & $14^{\prime} 891$ & 9.95 & $4{ }^{\prime} 085$ & 2.73 & - & 0.00 \\
With social security & $15^{\prime} 359$ & - & 0.00 & $1^{\prime} 098$ & 7.15 & $12^{\prime} 593$ & 82.0 & $11^{\prime} 292$ & 8.41 & 376 & 2.45 & - & 0.00 \\
Without social security & $134^{\prime} 375$ & $4^{\prime} 655$ & 3.46 & $9^{\prime} 144$ & 6.80 & $103^{\prime} 267$ & 76.8 & $13^{\prime} 600$ & 10.12 & $3^{\prime} 709$ & 2.76 & - & 0.00 \\
\hline Not classified & $21^{\prime} 136$ & - & 0.00 & 831 & 3.93 & $17^{\prime} 505$ & 82.8 & $1 ' 295$ & 6.13 & $1^{\prime} 505$ & 7.12 & - & 0.00 \\
\hline
\end{tabular}

Source: INEC, various years as processed by Sistema de información y análisis laboral/OIT 


\section{Policy Integration Department Working Papers}

No. 1 ILO activities on the social dimension of globalization: Synthesis report

No. 2 Measuring decent work with statistical indicators

Richard Anker, Igor Chernyshev, Philippe Egger, Farhad Mehran and Joseph Ritter

No. 3 Globalization and decent work: Options for Panama

Philippe Egger

No. 4 Globalización y trabajo decente: Opciones para Panamá Philippe Egger

No. 5 Indicators of social dialogue: Concepts and measurements Lane Kenworthy and Bernhard Kittel

No. 6 Assessing the impact of the attacks of 11 September 2001 on women's employment in the United States

Gertrude Schaffner Goldberg and Helen Lachs Ginsburg

No. 7 Decent work and the informal economy in Central America Juan Diego Trejos Solórzano and Miguel Del Cid

No. 8 Poverty initiatives in the ILO: A review of past and present approaches Pat Holden and Dagmar Walter

No. 9 Whither the International Standard Classification of Occupations (ISCO-88)? Debbie Budlender

No. 10 Improving occupational classifications as tools for describing labour markets: A summary of recent national experiences Debbie Budlender

No. 11 Recent developments in China's labour economy Thomas G. Rawski

No. 12 The Impact of economic liberalization on employment and wages in India Sonia Bhalotra

No. 13 The impact of trade liberalization upon inequality in developing countries Donald J. Robbins

No. 14 The impact of liberalization and globalization on income inequality in developing and transitional economies Giovanni Andrea Cornia

No. 15 The impact of technology transfer on employment and income distribution in developing countries: A survey of theoretical models and empirical studies Mariacristina Piva 


\section{Policy Integration Department Working Papers \\ Prepared by the World Commission on the \\ Social Dimension of Globalization}

No. 16 International finance: Meeting the needs of people in developing countries José Guilherme Almeida dos Reis

No. 17 The gender dimensions of globalization of production Stephanie Barrientos, Naila Kabeer and Naomi Hossain

No. 18 Social exclusion in the context of globalization - Jan Breman

No. 19 Gender and globalization: A macroeconomic perspective Çağatay Nilüfer and Ertük Korkurt

No. 20 Globalization, social exclusion, and work: with special reference to informal employment and gender - Marilyn Carr and Martha Chen

No. 21 Resources for social development - Antony Clunies Ross

No. 22 Does the new international trade regime leave room for industrialization policies in the middle-income countries? - Alisa DiCaprio and Alice Amsden

No. 23 Social dimension of globalization in Latin America: Lessons from Bolivia and Chile, Ivaro García Hurtado

No. 24 The social dimension of globalization: a review of the literature Bernhard Gunter and Rolph van der Hoeven

No. 25 The social dimension of global production systems: A review of the issues, Susan Hayter

No. 26 Reforming global economic and social governance: a critical review of recent programmatic thinking - Jeremy Heimans

No. 27 Corporate social responsibility: an issues paper - Michael Hopkins

No. $28 \quad$ Upgrading in global value chains - John Humphrey

No. 29 Implications of globalization and economic restructuring for skills development in Sub-Saharan Africa - Richard K. Johanson

No. 30 The outcome and impact of the main international commissions on development issues Frédéric Lapeyre

No. 31 Globalization and structural adjustment as a development tool - Frédéric Lapeyre

No. 32 Globalization and perceptions of social inequality - Malte Luebker

No. 33 The changing structure of international trade linked to global production systems: what are the policy implications? - William Milberg

No. 34 Corporate social responsibility: an overview of principles and practice,Jill Murray

No. 35 Inclusive development strategy in an era of globalization - Ignacy Sachs

No. 36 Social consequences of the globalization of the media and communication sector: some strategic considerations - Seán Ó. Siochrú

No. 37 Globalization, history and international migration: a view from Latin America Andrés Solimano

No. 38 Towards a different kind of globalization, or how the anti-globalists view the world Gijsbert van Liemt 


\section{Policy Integration Department Working Papers}

No. 39 How do trade union rights affect trade competitiveness? David Kucera and Ritash Sarna

No. 40 Statistics on the employment situation of people with disabilities:

A compendium of national methodologies

ILO Bureau of Statistics in collaboration with the In Focus Programme on Skills, Knowledge and Employability

No. 41 Employment in the informal economy in the Republic of Moldova ILO Bureau of Statistics in collaboration with the Department for Statistics and Sociology of the Republic of Moldova

No. 42 Decent work in a least developed country: A critical assessment of the Ethiopia PRSP Graeme J. Buckley

No. 43 Unemployment and Labour Market Institutions: The Failure of the Empirical Case for Deregulation Dean Baker, Andrew Glyn, David Howell and John Schmitt

No. 44 Women's access to occupations with authority, influence and decision-making power: Women as legislators, senior officials and managers around the world Richard Anker.

No. 45 The world of work in the context of economic integration and trade liberalization Daniel Martínez

No. 46 Poverty reduction in Pakistan: The strategic impact of macro and employment policies Moazam Mahmood

No. 47 Trends in Work Stoppages: A Global Perspective L. J. Perry and Patrick J. Wilson

No. 48 Generating decent work for poverty reduction in Cambodia: The voice of workers, employers and the Government Moazam Mahmood

No. 49 The Social Dimension of Regional Integration in ECOWAS René Robert

No. 50 Measuring trade union rights: A country-level indicator constructed from coding violations recorded in textual sources David Kucera

No. 51 Patterns of job quality attributes in European Union Joseph A. Ritter

No. 52 Child Labour, Education and Export Performance

David Kucera and Ritash Sarna 
No. 53 Measuring the informal economy: From employment in the informal sector to informal employment

Ralf Hussmanns

No. 54 Indicators of labour standards: an overview and comparison

Richard N. Block

No. 55 The pattern of globalization and some implications for the pursuit of social goals Gerry Rodgers

No. 56 Statistical indicators of social dialogue: A compilation of multiple country databases Anne Chataigner

No. 57 Trade unions and informal workers' associations in the urban informal economy of Ecuador, Catherine Vaillancourt-Laflamme 